\title{
ESTRUTURA AGRÁRIA, MODERNIZAÇÃO E DISTRIBUIÇÃO DA RENDA NA AGROPECUARIA CATARINENSE, EM 1980
}

\author{
MARIA SALETE [ZANCHET
}

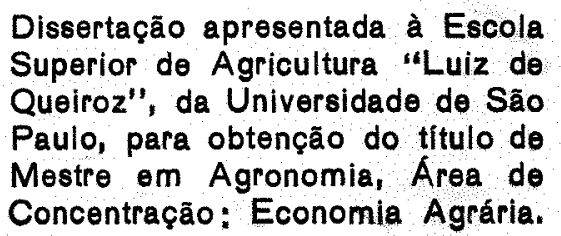

PIRACICABA

Estado de São Paulo - Brasil

Setembro - 1990 
ESTRUTURA AGRÁRIA, KODERHIZAGAO E DISTRIBUIGAO DA

\title{
RENDA NA AGROPECUARIA CATARINENSE, EH 1980
}

MARIA SALETE ZANCHET

Orientador: Frof. Ir. RODOLFO HOFFMANN

\begin{abstract}
Dissertacto apresentada a Escola Superior de Agricultura "Luiz de Queiroz", da Universidade de Sao Paulo, para obtengáa do titulo de Mestre ems Agronomia, Area de concentrafáa: Economia Agraria.
\end{abstract}

FIFACICABA

ESTADO DE SAO PAULO - BRASIL

SETEMERO - 1990 


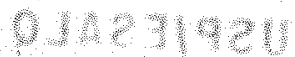

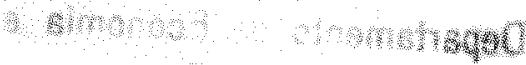

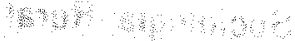 \\ W}

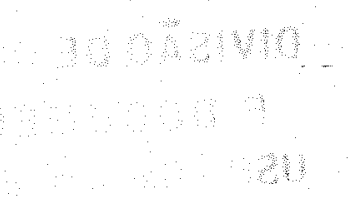

Ficha catalográfica preparada pela Seção de Livros da Divisăo de Biblioteca e Documentaçăo - PCAP/USP

Zanchet, Maria Salete

Z27e Estrutura agrária, modernicaçăo e distribuiçăo da renda na agropecuária catarinense, em 1980. Pirací caba, 1990.

$119 \mathrm{p}$. ilus.

Diss. (Mestre) - ESALQ

Bibliografia.

1. Agropecuária - Renda - Distribuição de renda

2. Estrutura agrária - Santa Catarina I. Esccla Sü perior de Agricultura Luiz de Queiroz, Piracicaba

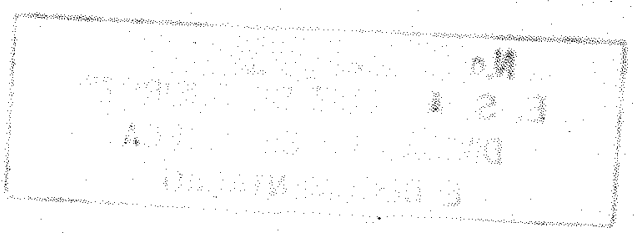

CDD 333.3 
ESTRUTURA AGRÁRIA, KODERMIZAGKO E DISTRIBUIGAO DA RENDA NA AGROPECUARIA CATARINENSE, EM 1980

\section{MARIA SALETE ZANCHET}
Aprovada em: 17.09 .1990
Comissao julgadora:
Prof. Dr. Rodolfo Hof fmann
ESALQ/USP
Prof. Dr. Oriowaldo Queda 304
ESALQ/USP
Prof. Dr. Luis Carlos Guedes Pinto
UNICAMP
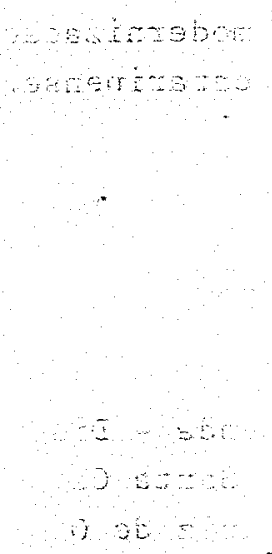

Prof. Dr. RODOLPO HOFFMANN . Orientador 
Todas as coisas tem seu tempo,

e todas elas passam debaixo do ceu

segundo o termo que a cada uma

foi prescrito. Ecl 3,1 .

Ao meu grande amigo, 
AGRADECIHENTOS

Inicialmente quero agradecer aos meus pais, Setembrino e Noemia Zanchet, pelo apoio e incentivo; e a minha filha Maria ceclia, por compreender o tempo que o curso e a dissertago the roubaram.

A Rodolfo Hoffmann, pela experiencia extremamente gratificante que foi o tempo de convivio ao seu lado. Sua atitude solidaria foi decisiva para a realizagáo deste trabalho.

A Oriowaldo Queda e a Carlos Jose Caetano Bacha, pela leitura cuidadosa dos originais e pelas contribuifos incorporadas ao trabalho. A Luiz Carlos Guedes pinto, pelas sugestoes e comentarios realizados.

A Osmar Alcides da Conceicăo e a Luiz Toresan, do Instituto de Planejamento e Economia Agricola de Santa Catarina, pelo apoio e pela leitura criteriosa dos originais; a Gilberto Alexandre de Campos, do Banco do Estado de Santa Catarina, pelo envio de bibliografia.

A Mauro Eduardo Del Grossi e a Ana Lacia Kassouf, pela amizade e pelo auxilio en diversas etapas do trabalho. 
A Marcelo Barata $E$ a Jorge Nery, companheiros em todos os momentos.

A Pedro Sinoes, a quem muitas vezes recorrl, a Elizabete Maria Neiva Negrao, pela datilografia das tabelas, e a Carlos Menrique Curupana, pelos desenhos.

A todos os professores e funcionarios do Departamento de Economia e Sociologia Rural da ESALQ/USP.

A CAPES e a FINEP, pelo suporte financeiro, e ao Governo do Estado do Parana, pela oportunidade de treinamento. 
SUHAR IO

Página

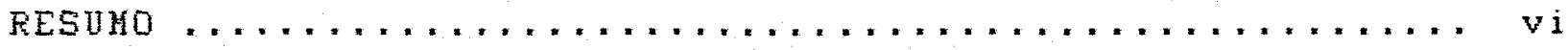

SUHHARY $\ldots \ldots \ldots \ldots \ldots \ldots \ldots \ldots \ldots \ldots \ldots \ldots \ldots \ldots \ldots \ldots \ldots \ldots \ldots \ldots \ldots \ldots$

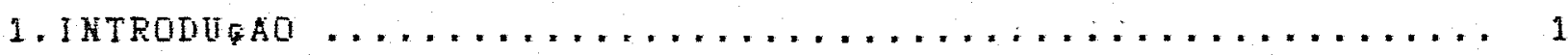

1.1. O Problema e Sua Importancia .................. 1

1.2. Objetivos Espectficos .................... 4

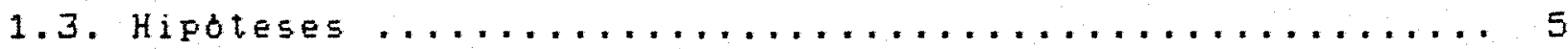

1.4. Organizagao e Metodo .....................

2. REUISAO IIE LITERATURA $\ldots \ldots \ldots \ldots \ldots \ldots \ldots \ldots \ldots \ldots$

2.1. As transformacos recentes na agricultura

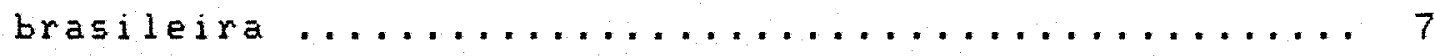

2.2. As relagóes entre modernizagăo e distribuigáo de

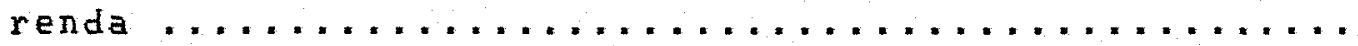

2.3. Aspectos da modernizaga na agropecuaria catarinense............................

3 - TRANSFORMAGOES FECENTES HA ESTRUTURA AGRAFIA E

CARACTEFISTICAS DA DISTRIEUIGAO IE RENDA NA

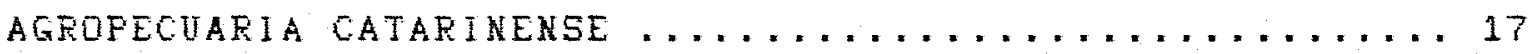

3.1. As Transformacoes na Estrutura Fundiaria ....... 17

3.2. As Transformages no llercado de Trabalho Agricola.. 32

3.3. Caracteristicas da Distribuiga da Renda na Agropecuaria Catarinense en $1980 \ldots \ldots \ldots \ldots . \ldots . . .40$ 
4. MOIERNIZAFAO E IISTFIEUIGAO DA RENDA NA AGROPECUARIA CATARINEMSE EM $1980 \ldots \ldots \ldots \ldots \ldots \ldots$

4.1. Estudo da Modernizago da Agropecuaria Catarinense .. 54 4.1.1. 0 conceito de modernizago agrloola e seus

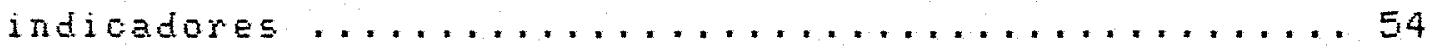
4.1.2. Ubtenta de fatores pelo metodo dos componentes

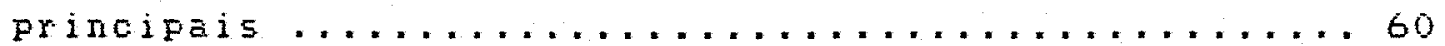

4.2. Resultados da Analiee Fatorial...............66 4.2 .1 . Os fatores de modernizaga $\ldots \ldots \ldots \ldots . \ldots 6$ 4.2.2. A caracterizaga regional ............72 4.2.3. Regióses diferenciadas quanto ao grau de modernizagao $\ldots \ldots \ldots \ldots \ldots \ldots 77$

4.3. Analise das Relagotes entre Modernizacá Agrloola e as Distribuigós da Renda e da Posse da Terra... 85 4.4. Resultados da Analise de Regressa ........... 87

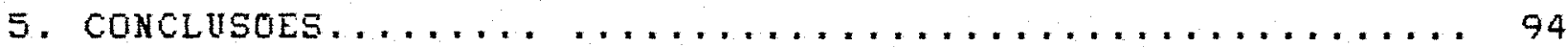
FEFERENCIAS BIBLIUGRAFICAS $\ldots \ldots \ldots \ldots \ldots \ldots \ldots \ldots$ APENDICE 1 - Construgäo dos indicadores ............ APENDICE 2 - Tabelas e histogramas ................ 110 


\section{ESTRUTURA AGRARIA, HODERHIZAGEO E DISTRIBUIGAO DA RENDA MA AGROPECUARIA CATARIHEHSE EY 1980}

\section{RESUYO}

0 trabalho teve como objetivo geral estudar a modernizagto e suas relagófs com a distribuiga da renda na agropecuaria catarinense em 1980. 0 estudo teve como fonte de dados os Censos Agropecuarios de 1970, 1975 e 1980 e censo Demografico de 1980; as unidades de observacao foram as microrregioes homogeneas de Santa Catarina.

Foram analisadas as transformagoes recentes na estrutura agraria e as caracteristicas da distribuicádo de renda na agropecudria catarinense em 1980. A caracterizafádo quadro agrario catarinense permite concluir que entre 1970 e 1980 houve aumento na desigualdade de distribuifádo posse da terra nas microrregioes homogeneas de Santa Catarina; pode-se afirmar tambem que a atividade agropecuaria catarinense ainda e conduzida de forma predominante pela famllia, No entanto, registra-se o crescimento da participaco relativa do trabalho assalariado.

o grau de modernizace na agropecuaria foi obtido atraves da analise fatorial pelo metodo dos componentes principais, com 18 indicadores. Foram obtidos tres fatores de modernizafăo que explican $83,91 \%$ da variancia total dos indicadores utilizados. os resultados da analise fatorial permitiram evidenciar 7 regioes diferenciadas quanto ao grau de 
vii

modernizafáo. A andise de regressăo năo confirmou a hipotese de que o processo de modernizagáo tende a ser acompanhado de um aumento no grau de desigualdade da distribuiga da renda na agropecuaria, para as condiques especificas de santa catarina. 
AGRARIAN STRUCTURE, MODERMIZATION AND INCOHE DISTRIBUTION IN AGRICULTURE PRODUTION OF SANTA CATARINA STATE, IN 1980.

SUMHARY

The general objective of this work is to study the modernization and its relations with the income distribution in agricultural prodution of Santa Catarina State, in 1980. The basic data are obtained from the agricultural censues of 1970 , 1975 and 1980 , and the demographic census of 1980 . The units of analysis are the sixteen microrregions of Santa catarina state.

The recent transformation in the agrarian structure and the characteristics of the income distribution in the agricultural sector are analized in the sixteen microrregions. It is shown that there was an increase in the inequality of the land tenure distribution in the microrregions of Santa Catarina State between 1970 and 1980 . It is also shown that the agricultural activity is still conducted by family labor. However, the growing of the hired labor participation is registered.

The degree of modernization in agricultural prodution was obtained with the factorial analyses through the 
method of princifal components and with 18 variables. Three factors of modernization were obtained, that explain $83,91 \%$ of the total variance of the 18 variables. The results of the factorial analyses Fermited to evidence seven regions with different degrees of modernization. The regression analyses did not confirm the hypothesis that the modernization process tends to be followed by an increase in the inequality of the income distribution in the agricultural production, for the specific conditions of Santa Catarina state. 


\section{IXTRODUৎAO}

\subsection{O Problema e Sua Importancia}

No perlodo compreendido entre 1967 e 1974, o Brasil ficou conhecido internacionalmente pelo acelerado crescimento de sua economia. Ao mesmo tempo, a repartifádo da renda havia se tornado mais regressiva, confirmando a evidencia empirica segundo a qual, nos estagios iniciais e intermediarios do desenvolvimento capitalista, ocorre aumento da desigualdade de distribuifa de renda.

No que se refere a agricultura, nos anos 70 observou-se a consolidaca das mudancas denominadas genericamente de "modernizacao". A concretizaca destas mudancas, entretanto, foi possibilitada pelas transformacos ocorridas na economia brasileira a partir de meados da decada de 50, tais como a entrada de capital internacional para o setor industrial e o aperfeigoamento do setor financeiro. 0 estabelecimento dos ramos industriais para a producao de bens de capital e de consumo fara a agricultura tambén ocorreu em meados da decada de 50. 
Com a constituigáo do Sistema Macional de Credito Rural (SNCR) em 1965, ofinanciamento agricola se tornou o principal mecanismo de incentivo a mudanga tecnologica e atuou ampliando a venda de produtos industriais para a agropecuaria. 0 credito rural subsidiado privilegiou uma minoria de proprietarios rurais, tendo em vista que a possibilidade de aquisiolo de bens e insumos industriais, via financiamento agricola, era vinculada a garantia do patrimonio fundidrio. A manutengáo da estrutura fundiaria e a integragáo da propriedade fundiaria no processo de modernizafáo, mediante a ampliacáo e o favorecimento da divida hipotecaria rural sa fatores que contribulram para agravar a concentraca fundidria e a desigualdade da distribuifáo de renda.

A difusalo das relacós capitalistas de produfáo, atraves do assalariamento do trabalhador rural, também e apontada como uma consequencia do processo de modernizagáo.

A intensificagăo da produgăo agricola e un fenomeno encontrado, em maior ou menor grau, em fraticamente todo - territorio nacional. Observou-se a introduca ou o avanfo de lavouras de cana-de-actcar, trigo e soja, algodao, milho, arroz irrigado, entre outras. Essa pauta de produtos agricolas intensificou a integracá ao complexo agroindustrial. Aprofundouse a articulaca da produca agropecuaria, por un lado, com a industria Frodutora de insumos e bens de capital para a agricultura, e, por outro lado, com a industria processadora de produtos agricolas. 
Portm, ao mesmo tempo em que ocorrian as mudanfas na base tecnica e a aricultura intensiva se expandia, aumentava a concentrapgo fundiaria e a desigualdade de distribuiga da renda na agropecuaria. Existem evidencias emplricas de que a modernizaca agricola, embora tenha contribuldo para elevar a renda media e reduzir a pobreza absoluta, associa-se fortemente ao aumento de desigualdade distributiva.

o Processo dinanico registrado para a agricultura brasileira certamente náo deixou de ter seus reflexos em santa Catarina. A agricultura catarinense tem certas caracteristicas que devem fazer com que a modernizago, nesse estado, se diferencie das transformaofes havidas em outras unidades da Federafáo. Como peculiaridade da agropecudria catarinense, citase a predominancia da pequena propriedade e da mao-de-obra familiar, com producáo de lavouras alimentares e criaglo de animais de pequeno porte; comparativamente a outras unidades da Federafo, apresenta indices relativamente menores de concentraca fundiaria e de desigualdade de distribuifáda renda. Entretanto, existem poucos estudos socio-economicos mostrando como se manifesta o desenvolvimento capitalista recente na agropecuaria catarinense.

Ferguntar-se-ia, entao, qual o grau de modernizacto na agropecuaria catarinense? Dado que nem sempre o desenvolvimento capitalista homogeiniza as relagos de producto, haveria regioes diferenoiadas quanto ao grau de modernizafá agricola? As evidencias empiricas relacionando aumento de desigualdade de distribuigáo da renda com a modernizafao na 
agropecuaria tamben sáo validas para Santa Catarina?

Para responder estas questoes, desenvolveu-se uma pesquisa emplrica, conduzida tendo como referencial a andise da modernizacáo na agropecuaria brasileira e suas relaqốs com a distribuifto da renda, proposta for HOFFMANN et a $\underline{\text { I }}$ i $(1985$ ), aplicada para as condigbes da agropecuaria catarinense.

\subsection{Objetivos Especificos}

o objetivo geral do trabalho e estudar a modernizagáo na agropecuaria catarinense e suas relacoes com a distribuifo da renda en 1980. Destudo proposto tem como unidades de observaco as 16 microrregioes homogeneas de Santa Catarina e como fonte de dados os Censos Agropecuarios de 1970 , 1975 e 1980 , e o Censo Demografico de 1980. Especificamente, pretende-se atingir os seguintes objetivos:

- evidenciar as transformacos recentes na estrutura agraria;

- evidenciar as caracteristicas da distribuifáda renda na agropecuaria;

- evidenciar o grau de modernizaca na agropecuaria e a existencia de regioes ou zonas com graus diferenciados de modernizacao agricola;

- evidenciar as relacoes entre o processo de modernizaca na agropecuaria e a distribuifáo da renda e da posse da terra. 


\subsection{Hipoteses}

Farte-se da hipotese central de que tende a existir uma associaca positiva entre o grau de modernizacto agricola e o grau de desigualdade ra distribuicuo da renda ra agropecuaria, conforme constatado por HOFFHANN et a 1 íl(1985), TRONCOSO LEONE( 1988), KIYUNA(1989) E DEL GROSSI(1989). Procura-5e mostrar a validade dessa hipbtese para Santa Catarina.

$$
\text { Ainda de acordo com os trabalhos citados }
$$
anteriormente, admite-se, como hipdteses complementares, que:

- o processo de modernizaca e acompanhado de uma melhoria nos niveis de renda, com elevacáo de renda media e redufao da pobreza absoluta;

- as variages na desigualdade da posse da terra estgo diretamente associadas as variacoes da desigualdade na distribuiga da renda originada de atividades agropecuarias.

\subsection{Organizacáo e Metodo}

Admitindo que a modernizaga agrloola tem reflexos sobre a estrutura agraria, no Capitulo 3 sao analisadas as transformafos recentes na estrutura fundiaria e nas relacos 5ociais de producáo. Em funoa de suas peculiaridades, apresentase também uma analise da distribuiqúo da renda na agropecuaria catarinense em 1980. Alem de compor o quadro agrario catarinense, - Capltulo 3 culare o proposito de introduzir os dados de distribuigáde de renda, distribuioáo da posse da terra e pobreza, 
utilizados no Capltulo 4. O terceiro capitulo e mais descritivo e com ele pretende-se atingir os dois primeiros objetivos especificos deste trabalho.

No Capitulo 4 esta a pesquisa empirica desenvolvida para atingir os demais objetivos. De acordo com estes objetivos, a pesquisa envolve duas etapas distintas. Inicialmente foi feito um estudo sobre a modernizaso na agropecuaria, utilizando a andise fatorial e, em seguida, foi feito o testedas hipoteses, atraves da andise de regressa. No caso especifico do Capitulo 4, a fase descritiva e representada pelo estudo da modernizaóo agricola e e uma etapa intermedidria da pesquisa; a fase explicativa e representada pela analise das relacos entre modernizaplo agricola edistribuicáo da renda, distribuiço da posse da terra e pobreza. A apresentafóo dos resultados obedece a ordem de execugáda pesquisa. 


\section{REVISAO DE LITERATURA}

\subsection{As Transformacos Recentes na Agricultura Brasileira}

$$
\text { - desenvolvimento capitalista recente causou }
$$

profundas mudangas na sociedade brasileira. Este tema tem sido analisado sob os mais diversos angulos, e continua despertando interesse para novas pesquisas, tal a amplitude das transformacoses ocorridas. O desenvolvimento agricola no Erasil tem chamado a atengăo em funga das distorobes sociais e ambientais causadas pelo modelo adotado.

$$
\text { MESQUITA et } \underline{\text { a }} \text { í }(1977) \text { desenvolveram um estudo }
$$

que pode ser considerado pioneiro na analise da modernizacáo agricola brasileira, com auxilio de andise fatorial como metodo estatistico. Foram utilizados 28 indicadores de modernizafóa 361 microrregioes homogeneas do Brasil como unidades de observafo. Foram empregados os dados do Censo Agropecuario de 1970.

$$
\text { Os indicadores construidos procuram refletir a }
$$
cafitalizafo da agricultura, direta e indiretamente. Foram consideradas as relacos sociais de produco, o uso de mecanizagáo a utilizaqúo da terra. 
brasileira e sua distribuiaco espacial e conseguida atraves da andise fatorial. Este procedimento estatistico possibilita individualizar dimenstes subjacentes ao conjunto de indicadores solecionados, e permite aferir as desiqualdades regionais atraves do posicionamento das unidades de observagáo ao longo das dimenstes identificadas.

Os autores concluen que existem grandes contrastes regionais: a Regiăo Centro-sul, apresenta-se modernizada ou em niveis de maior integraco ao processo de modernizaco; as Regioes Norte e Nordeste apresentam areas restritas modernizadas ou em processo de modernizaco e vastas areas nó integradas a esse processo.

Para $50 R J(1980)$, com a modernizaca agricola, uma nova estrutura de classes emerge, decorrente do modelo de desenvolvimento adotado. Em termos de relacoes de produca e desenvolvimento das foras produtivas, esta nova estrutura compoe-se de 3 grandes setores caracteristicos: setor de empresas fundadas na relaca de produca capitalista e tecnologia moderna; setor de empresas familiares, fundadas no trabalho familiar, com pouca ou nenhuma utilizacáo de trabalho assalariado; setor de produca tradicional, baseado na pequena propriedade familiar, ou arrendamento e parceria, e na pecuária extensiva.

o desenvolvimento capitalista na agricultura nao repercutiu de forma homogenea las diversas regibes, uma vez que as caracteristicas predominantes da agropecuaria diferen de uma regiso para outra. Entretanto, o desenvolvimento da agricultura 
eII geral aprofundou as desigualdades entre classes e entre estratos de produtores.

MULLER (1980) procurou demonstrar que, no intcio dos anos setenta, o Brasil dispunha de un conjunto de setores industriais e agricolas interdependentes entre si. Este conjunto, en geral, ten sido denominado de Complexo Agroindustrial (CAI), e define os processos tecnicos, economicos e politicos que envolvem a producáo agricola, o beneficiamento e sua transformafă, a produoto de bens industriais para a agricultura e os servifos financeiros e comerciais correspondentes.

o autor observa que, por volta de 1970, grande parte da produgáo agricola brasileira esta direcionada aos interesses industriais. Os setores demandantes de materia-prima tem na agropecuaria seu principal fornecedor. Por sua vez, as condicoes de froducgo na agricultura se integram, cada vez mais, a industria de maquinas e demais insumos industriais.

Com o crescimento da agricultura industrializada, que materializa os interesses sociais modernos, as mudanfas se estenden a estrutura social. No movimento de transformaca da agricultura brasileira, fode-se afirmar que nenhuma camada social se mantem alheia a sua influencia. Este movimento de transformago atinge inclusive aquelas camadas que nao se enquadram nas atividades agricolas en industrializafáo.

DELGADO (1984) interpretou a participacáo do 
capital financeiro no desenvolvimento econonico recente da agricultura brasileira, abrangendo o periodo de meados da decada de 60 ate a crise econamica do inicio dos anos 80. Na primeira parte do trabalho, caracteriza, em grandes trafos, o desenvolvimento recente da agricultura brasileira, enquanto na segunda parte analisa a constituifóa o desenvolvinento do capital financeiro no setor agricola nacional.

a trabalho de DELGAIO explica como o sistema de credito consolidou a implantaga do Complexo Agroindustrial a montante e a jusante da agricultura. Fica claro que a modernizaca, alem de desenvolver a agricultura, fortaleceu as relafoes interindustriais, sob o patroctioio do sistema financeiro oficial.

FUENTES LLANILLO (1984) caracterizou a estrutura de produfáo agropecuaria do Estado do Parana e de suas vinte e quatro microrregioes homogeneas, atraves de andise fatorial. Foram utilizados dados dos Censos Agropecuarios en tres cortes temporais: 1970, 1975, 1980. Analisou trinta indicadores relacionados aos aspectos de estrutura fundiaria, uso da terra, uso de tecnologia e capital, emprego e relacoes de trabalho, e recursos naturais. Com os resultados da andise fatorial para 1980, foi possivel realizar um zoneanento com oito regiós distintas quanto a estrutura agraria.

Este trabalho representa mais una contribuigáo aos estudos ja realizados sobre as transformabes recentes na agropecuaria paranaense. Dada a boa descrioto da metodologia 
adotada, tem sido utilizado como modelo para as pesquisas sobre modernizaca com uso de analise fatorial.

\subsection{As Relacoses entre Modernizacalo e Distribuiga de Renda}

No contexto da litcratura sobre desenvolvimento economico, uma das questeres náo plenamente resolvidas e fato de - crescimento e a distribuigăo de renda constituirem objetivos complementares ou antagonicos. Nos meios academicos, o que prevalece e a hipotese de Kuznetz (1955), segundo a qual, nos estagios iniciais e intermediarios do desenvolvimento de um pals, o mecanismo que promove o crescimento acompanhado pelo aumento da desigualdade distributiva.

No entanto, um ntmero crescente de teoricos tem rejeitado esta hipotese. Fara estes autores, a distribuifád de renda édeterminada tanto pelo nivel de desenvolvimento cmedido pela magnitude da renda "per capita") quanto pelas politicas e estrategias de desenvolvimento economico adotadas no pais. Desta forma, admitem que: a distribuicáo de renda ná deve necessariamente piorar antes de se tornar menos desigual o crescimento no e prejudicial as classes populares; e sao contrarios a ideia de que para haver crescimento rapido nao pode haver menos desigualdade (FIELDS, 1980 ; CLINE, 1975 ).

BAY-PETERSEN(1986) cita o exemplo de Taiwan, onde um bem sucedido programa de reforma agraria conferiu igualdade social na zona rural, e deu ao agricultor a terra para ele cultivar e os rendimentos decorrentes de seu trabalho. 0 sistema 
de comercializagáo confere lucros ao agricultor e năo ao intermedidrio. Outra politica que aparentemente influenciou o desenvolvimento agricola en Taiman, foi o desenvolvimento industrial descentralizado, que difundiu fabricas e, portanto, rendas industriais, no interior. Em 1980, mais de $90 \%$ dos agricultores de Taiman trabalhavam na agrioultura em tempo parcial, dedicando parte do tempo para o trabalho no setor industrial. Parte expressiva da renda destes agricultores provinha do setor industrial.

Embora o exemplo de Taiwan sirva para mostrar que possivel ocorrer mudanqa tecnoldgica sem necessariamente haver amento da desigualdade distributiva, este ná e caso do ocorrido no Brasil, como revelam as pesquisas empiricas ja realizadas.

No Brasil, a influencia direta do processo de modernizaca na evoluga da distribuiga de renda entre a Populasa economicamente ativa (PEA) na agricultura foj

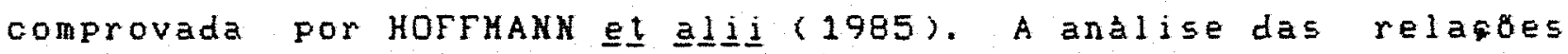
entre o grau de modernizaco da agricultura na decada de 70 e as variafoses de renda "per capita" para 22 unidades da Federafa confirma a hipotese de que a modernizago agricola e acompanhada pelo aumento da desigualdade.

Os efeitos da modernizaco sobre desigualdade, rendimento medio e pobreza foram comprovados empiricamente por HOFFMANN \& KASSOUF (1989). Nesta analise foram utilizados 31 indicadores de modernizaga e obtidos 3 fatores, aos quais 
corresfonden $74 \%$ da variancia total. As unidades de andise foran as microrregibes homogeneas (MRH) de Säo Paulo, Parana, Santa Catarina, Rio Grande do Sul, Mato Grosso, Mato Grosso do Sul, Bahia e Perrambuco.

As hipoteses relativas a modernizaco e a renda agricola foram testadas, alternativamente, com duas distribuifos de renda: entre pessoas de familias cujo chefe tem atividade principal na agropecuaria, e entre pessoas economicamente ativas (PEA) na agropecuaria, com rendimento. Na primeira alternativa, o fator de ponderasa utilizado foi o ntmero total de pessoas das familias para 158 MRH; na segunda alternativa, o fator de ponderacáo passa a ser o nomero de pessoas da PEA em cada MRH. Neste caso, por falta de dados para Santa Catarina, o nomero de observafbes 142 .

Os efeitos da renda sobre a pobreza absoluta dependem da forma da distribuioáo de renda. A elevacáo da renda media, sem que ocorra aumento de desigualdade, geralmente leva a uma redufáo na pobreza. Por outro lado, aumento de desigualdade, sem correspondente aumento de renda media, provoca aumento na pobreza. Os autores conoluen que, a modernizacáda agricultura, nas condifoes sdcio-economicas do Brasil, determina simultaneamente uma elevaga do rendimento medio e um aumento da desigualdade.

TRONCOSO LEONE ( 1988 ) confirmou a hipotese de que a modernizaglo na agropecuaria baiana esta associada a maiores 
niveis de renda, menor pobreza e maior desigualdade. o conceito de modernizacto foi operacionalizado atraves de 18 indicadores, relacionados com intensidade de exploraco da terra, Frodutividade do trabalho, uso de trabalho assalariado, financiamentos e escala do empreendimento. A distribuifa de renda selecionada e referente a pessoas economicamente ativas (PEA) na agropecuaria, de acordo com o Censo Demografico de 1980 , que tiveran rendimentos no nulos. o fator de ponderafo utilizado foi o ntmero de pessoas economicamente ativas na agropecuaria de cada microrregiso homogenea.

DEL GROSSI ( 1989 ), utilizando dados do Censo Demografico para 1970 e 1980, analisou a distribuiga de renda nas microrregioes homogeneas do Farana. o autor observou uma correlafo significativa e positiva entre renda media e desigualdade da distribuicalo de renda. As microrregiós homogeneas que sofreram con maior intensidade o processo de modernizacgo na decada de 70 apresentaram tambem maiores indices de desigualdade economica. No Farana, ficou evidenciado que as microrregioes homogeneas com maiores aumentos de renda media sao aquelas que experimentaram maiores elevacoes na desigualdade da distribuigéfo de renda.

Com relacto a populacao que permaneceu no setor agropecuario, IEL GROSSI afirma que a renda gerada pelo processo de, modernizago no Parana beneficiou um nomero restrito de pessoas do meio rural. Tal situaga provocou uma elevaca na desigualdade da distribuiga de renda e manteve a pobreza na agropecuaria paranaense. 


\subsection{Aspectos da Hoderniząăo na Agropecuária Catarinense}

Como ja entatizado na introduose, existem poucos trabalhos neste campo de pesquisa com dados de Santa Catarina. De maneira geral, os estudas encontrados referem-se a alguma regiao especifica ou a alguma alividade relevante, como suinocultura, avicultura ou produca de fumo. Na revisao feita, encontrou-se apenas o trabalho de HESS (coord., 1983), cujo objetivo principal foi o de analisar o impacto da expansa das culturas voltadas as alternativas energeticas a exportaca sobre a agricultura de alimentos. Os indicadores de modernizacáo utilizados foram: ndmero de tratores, ocupapa da máo-de-obra por categoria, estrutura fundiaria e utilizaga das terras. os dados foran agregados segundo grandes regioes: Litoral Norte, Litoral Sul, Planalto e Deste. Usando dados de 1970 e 1975, os autores concluem que a expansa do progresso tecnico ocorreu de forma adequada as condicoes de produco na agropecuaria catarinense. Admitem tamben que a modernizaca tenha se irradiado de maneira uniforme no Estado.

A integraca entre a agricultura e a indtstria tem em Santa catarina manifestaces bem sucedidas, como o complexo agroindustrial ligado acriacóde sulnos e aves, é á culturado fumo. Alias, o parque industrial de frango e sulnos que acaba conferindo a essa produca e ao produtor certa estabilidade, que se traduz na manutencóo ate mesmo na consolidacóo da estrutura de Froduso vigente, notadamente no oeste catarinense. Outro 
aspecto importante $e$ o fato de o fumo ter sido o vetor da modernizago ocorrida nas regibes leste e sul catarinense. A cultura do fumo conta com un pacote teonologico proprio, fornecido feles industrias. Estas controlam todo o processo produtivo, assunindo responsabilidade frente aos agentes financeiros e induzindo a incorporaga de tecnologia e a utilizacáo de insumos modernos.

A lavoura de cana-de-agtacar tem sido caracterizada pela grande absorcto de tecnologia. Na microrregio homogenea 293-Litoral de Itaja1, onde há produca parafins industriais, nao ten sido diferente. Alem de ter apresentado acrescimos de Frodutividade, tornou-se altamente concentrada. 0 autoabastecimento se fortalece no inicio dos anos 70 , quando as usinas substituem gradativamente a froduo áo de fornecedores pela producáo propria. 0 cultivo proprio, que representava cerca de 35* da cana molda pelas usinas no inicio da decada, passa para mais de $70 \%$ no final da decada.

En conclusa, pode-se perceber que a modernizafa agricola en Santa Catarina esta ligada a aspectos especificos no que se refere a lavouras e a produca de origem animal. No entanto, no que se refere as questoes teoricas da logioa de producto capitalista na agricultura, efossivel ferceber que Santa catarina no ficou a nargen do processo de mudanas associadas d modernizago. 
3. TRANSFORHAFOES RECENTES NA ESTRUTURA AGRARIA E CARACTERISTICAS DA DISTRIBUIFAO DA RENDA NA AGROPECUARIA CATARIMEUSE

A inclusa deste capltulo tem por objetivo apresentar as caracteristicas a as transformaces da estrutura agraria catarinense na decada de 70 , bem como as caracterlsticas da distribuica da renda e da pobreza na agropecuaria em 1980. As medidas aqui apresentadas será utilizadas na analise de regressao do Capltulo 4 e comenta-las contribui para a compreensao dos resultados obtidos.

\section{1 - As Transformactes na Estrutura Fundiaria}

Antes de analisar as transformacoes recentes na estrutura fundiaria catarinense, e oportuno apresentar alguns aspectos historicos da ocupago de Santa Catarina. Seguindo a orden cronológica de povoamento das diversas regioes, sintetizada na Figura 1, apresenta-se uma breve retrospectiva do processo de ocupaga, de acordo com CEFA/SC(1978).

A ocupaczo do territorio catarinense teve intoio 
com o povoamento vicentista, no seculo XVII, na faixa litoranea, com a fundaga dos nucleos de Sáo Francisco, Desterro e Lagua. Apos o povoamento vicentistay registra-se a ocorrencia da colonizafóto aqoriana (1748-1756). Esta ocupou a llha de Santa Catarina e parte do continente, na regiao compreendida entre sao Miguel E o litoral sul, proximo a Laguna. Os ndoleas aforianos foram assentados tendo por base a pequena propriedade. A atividade agricola nos moldes europeus nao vingou e os aforianos se dedicaram a pesca e á produca de farinha de mandioca. Nos dois primeiros seculos de sua ocupacar Santa Catarina servia como apoio logistico a atividade militar, o que pode ter contribuido para o fracasso da atividade agricola das populafos que se estabeleceran nesta epoca.

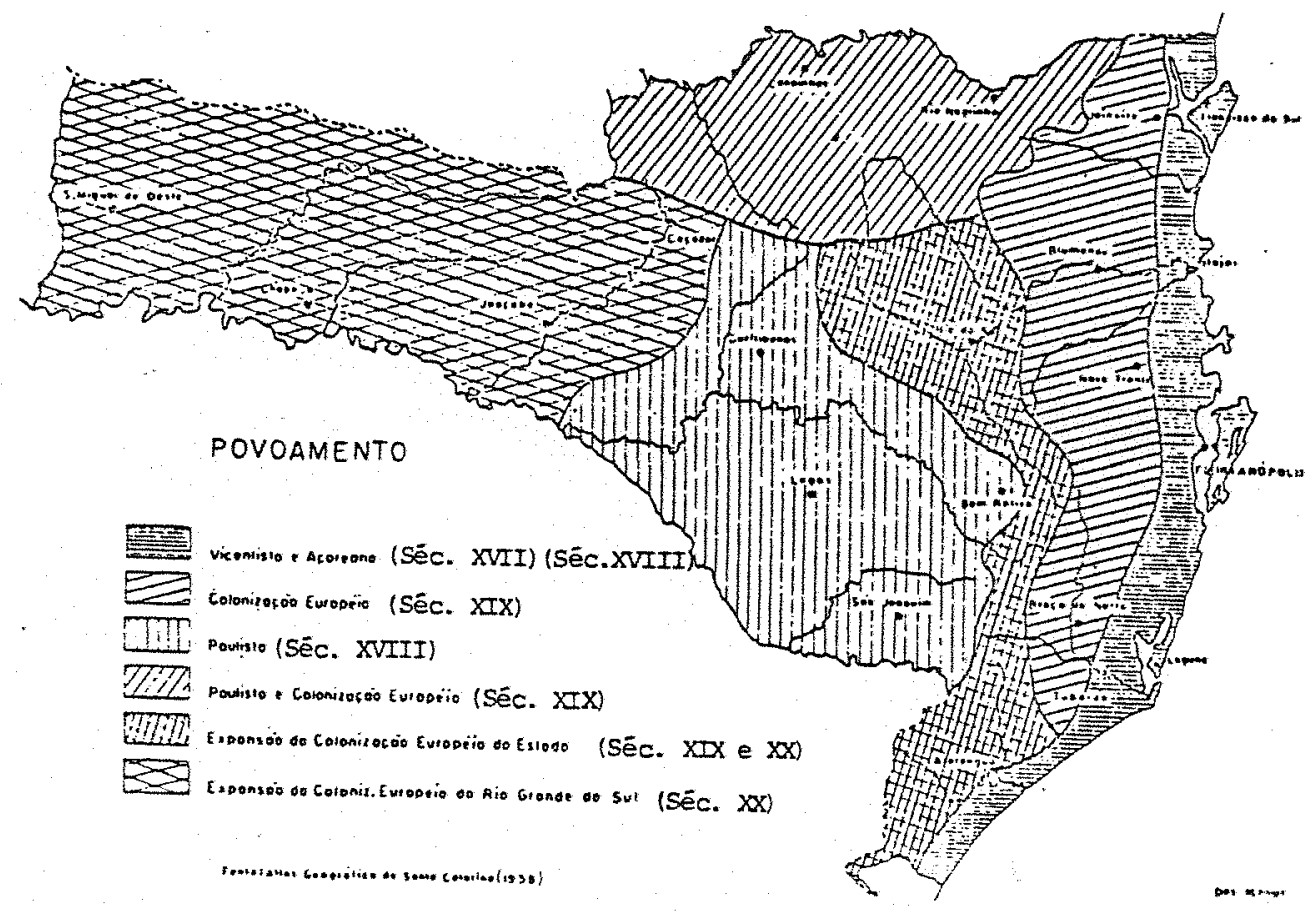

Figura 1 - Povoamento de Santa Catarina, segundo a orden cronologica de ocupaqúo e origen da populagăo. 
Em meados do seculo xVIII ocorreu a ocupaca do planalto, caracterizado pelo ciclo do tropeirismo. o estabelecimento dos "caminhos do sul", via terrestre, consolidou Lages como area de criagto pentreposto de gado. Os caminhos do sul determinaram tambem o surgimento de Sa Joaquim, Mafra, Forto Uniao, entre outros povoamentos. Nesta epoca, os paulistas dominavam a comercializaca de gado, que se destinava as regioes mineradoras da Serra da Mantiqueira. A grande propriedade, talvez originaria da concessato de sesmarias, passou a ser a unidade tipica do flanalto catarinense.

outra fase, distinta das anteriores e de grande relevancia para a ocupacáo de Santa Catarina, foi a inigragăo de europeus. A instalapăo de imigrantes europeus teve inicio em 1828, con a fundaga da Colonia de Săo Pedro de Alcantara, proxima a Desterro (hoje Floriandpolis). Segue-se a criacto das colonias alemas no litoral norte CDona Francisca, 1849, hoje Joinville) e no Vale do Itajal (Blumenau e Erusque, 1850). A colonizacto italiana foi mais difusa que a alem, e se localizou Frincipalmente no sul do Estado, a partir de 1875, originando Brafo do Norte, Crisciuma, Urussanga. A colonizafto polonesa ocorreu entre 1882 e 1900 , contribuindo para a formaga de Turvo, Orieas, Grao Para. D estabelecimento das colonias com inigrantes de diversas etrias baseou-se na propriedade familiar, com vistas auta-suficiencia.

A regiao do oeste catarinense foi marcada por muitos conflitos, que de certa forma atrasaran sua ocufag:o: 
confitos violentos com indios no seculo passados litigio de fronteira com a Argentina, solucionado en 1903; o oeste e parte do planalto foram area de litigio entre Parana e Santa catarina, solucionado em 1915; e a Guerrado Contestado (1912/1916). A Partir de 1920, ocorreram os fluxos de migrafto para o oeste, que recebeu populagáo oriunda das colonias do noroeste gatcho (descendentes de italianos e alemás). A organizafódo destas colonias tamben teve por base a pequena propriedade familiar e a diversificagáo agropecuária.

o processo de imigraca para santa catarina, iniciado com a colonizaquo europeia no seculo passado, ao que tudo indica, nato estava encerrado em meados deste seculo. Ainda na decada de 70 , observou-se o movimento migratorio de agricultores japoneses para o planalto catarinense.

\section{E oportuno dizer que os inigrantes que se} dirigiram a Santa Catarina ocuparam as terras na condifa de proprietarios. En outras regioes, a migragao esteve ligada ao acesso indireto a terra, seja atraves do assalariamento ou atraves da parceria. Um exemplo tipico do acesso indireto a terra e o colonato do cafe, que ocorreu en sáo Paulo e no norte do Parana. A condifáo de proprietdrio dos meios de producáo, com predominancia de pequenos proprietarios, confere caracteristicas proprias a estrutura agraria catarinense.

Para analisar as transformacoes recentes na estrutura fundiaria em Santa Catarina e em suas lo microrregioes homogeneas e importante verificar a evoluožo da desigualdade de 
distribuifa da fosse da terra. Para tanto, foran utilizadas as informabes de ntmero e area total dos estabelecimentos asropecuarios, for grupo de area, dos censos Agropecuarios de 1.70, 1975 e 1980. Com estes dados foram calculadas medidas de Findencia central e da desigualdade de distribuigáo da posse da terra, a seguir apresentadas.

Ao analisar a distribuica da posse da terra, e preciso definir o que se entende por estabelecimento agropecuario. O IBGE, em 1970, considera estabeleoimento agropecuario como "todo terreno, de area continua, independente do tamanho, formado por uma ou mais paroelas confinantes, sujeito a uma unica administracáo, onde se processasse uma exploracáo agropecuaria, ou seja: o cultivo do solo con culturas permanentes ou temporarias, inclusive hortalicas e flores; a criafao, recriafo ou engorda de gado; a criaca de pequenos animais; a silvicultura ou oreflarestamento; e a extraca de produtos vegetais. Excluiram-se da investigagáo os quintais de residencias e as hortas domesticas." (IBGE, 1975, P. XX)

A conceituago de estabelecimento no censo Agropecuario de 1975 diferiu da utilizada no censo Agropecuario de 1970 afenas pelo criterio de considerar, como um trico estabelecimento, parcelas descontinuas localizadas em um mesmo Setor de enumeraca. No Censo Agropeousio de 1975, "as paroelas na confinantes exploradas em conjunto por un mesmo Produtor, foram consideradas como um trico estabelecimento, desde que estivessem situadas no mesmo setor e utilizassem os mesmos 
recursos tecnicos (maguinas, implementos e instrumentos agrarios, animais de trabalho, etc) e os mesmos recursos humanos ( o finesmo pessoal), estando subordinadas a uma tnica administraso (do Produtor ou de um Adninistrador ${ }^{n}$ (IBGE, 1979, F. XXIII). Fara 1980, foi adotado criterio identico ao do Censo Agropecuario de 1975.

Com a mudanca no conceito de estabelecimento entre 1970 e 1975 espera-se que ocorra un ligeiro aumento na area media e na trea mediana, e que as medidas de concentracto sejan pouco afetadas (HOFFKANN, 1982 ).

Em Santa Catarina, o ntmero de estabelecimentos agropecuarios cresceu de $207 \mathrm{mil}$ em 1970 para quase 216 mil em 1980,0 que corresponde a um crescimento de apenas $4 \%$. A area ocupada passou de $7025 \mathrm{mil}$ hectares en 1970 , para 7474 mil hectares em 1980, crescendo 6 * na decada. A nivel de microrregiăo homogenea a situacáo foi diferenciada, cabendo alguns destaques. As microrregioes homogeneas 292-Colonial de Joinville, 293-Litoral de Itajai, 294-Colonial de Blumenau, 301Litoral Sul e 305-Colonial do Rio do Feixe apresentaram reducăo do ntmero e aumento da drea total dos estabelecimentos agropecuarios. A redugálo mais drastica ocorreu na microregia homogenea 293-Litoral de ltajal, e esta associada a un processo de concentraga fundiaria. As miororregibes homogeneas $296-$ Colonial do Alto Itajal, 29s - Litoral de Laguna, 30o-Colonial do Qeste catarinense e 307-Planalto de canoinhas, ao contrarios apresentaram aumento do numero e da area total dos estabelecimentos agropecuarios. Estas microrregibes homogeneas 
deven ter constituido a "area de fronteira" dentro de Santa Catarina, na decada de 70. Estes dados concordam com os registros de PIAZZA (1975), que ceracteriza estas regibes como sendo as de ocupacto mais recente, dentro do contexto historico catarinense. As demais miororregioes homogeneas apresentaram relativa estabilidade, com alterafós pouco expressivas, como mostra a tabela 1 .

A tabela 2 apresenta a evoluca das areas media e mediana dos estabelecimentos agropecuarios catarinenses entre 1970 e 1980. A area nedia e obtida dividindo-se a area total dos estabelecimentos pelo numero de estabelecimentos. Quando os estabelecimentos sao ordenados pelo valor de sua area, a mediana e o valor que e precedido e seguido pelo mesmo nomero de estabelecimentos.

A area media e a área mediana sofreram pouca alterafa, no Estado, apesar da mudanga do conceito de estabelecimento agropecuario. As microrregioes homogeneas, entretanto, apresentaram tendencia diferenciada, principalmente no que se refere átrea media. As microrregioes homogeneas 292Colonial de joinville, 293-Litoral de ltajal, 294-Colonial de Elumenau, 297-Floriandpolis, 301-Litoral sul catarinense, 305Colonial do Rio do feixe, 306-Colonial do oeste Catarinense e 307-Planalto de Canoinhas apresentaran, entre 1970 e 1980, uma taxa de crescimento da area media superior a observada para o Estado. Novamente, o destaque e a miororregiao homogenea $293-$ Litoral de ltajal, com acrescimo de quase $90 \%$ na area media. For 
TABELA 1 - Nümero e àrea total dos estabelecimentos agropecuārios em Santa Catarina e nas suas 16 microrregiōes homogēneas, em 1970, 1975 e 1980.(1)

\begin{tabular}{|c|c|c|c|c|c|c|c|c|c|}
\hline \multirow{2}{*}{$\begin{array}{l}\text { MICRORREGIAO } \\
\text { HOMOGENEA }\end{array}$} & \multicolumn{3}{|c|}{ NOMERO DE ESTABELECIMENTOS } & \multicolumn{6}{|c|}{ AREA TOTAL DOS ESTABELECIMENTOS } \\
\hline & 1970 & 1975 & 1980 & & 1970 & & 1975 & & 1980 \\
\hline 292 - Colonial de Joinville & 8034 & 7353 & 7204 & & 169511 & & 153301 & & 186773 \\
\hline 293 - Litoral de Itajai & 2291 & 1916 & 1487 & & 43765 & & 45226 & & 53783 \\
\hline 294 - Colonial de Blumenau & 18833 & 17825 & 16804 & & 359171 & & 326381 & & 391011 \\
\hline 295 - Colonial Itajai Norte & 4442 & 4977 & 4520 & & 121808 & & 114312 & & $122 \cdot 910$ \\
\hline 296 - Colonial Alto Itajaí & 12603 & 13822 & 14746 & & 341403 & & 320.244 & & 359.232 \\
\hline 297 - Florianöpolis & 6474 & 5694 & 5030 & & 120558 & & 101063 & & $110 \quad 170$ \\
\hline 298 - Colonial Serrana & 8734 & 8. 356 & 8477 & & 314767 & . & 295151 & & 310.017 \\
\hline 299 - Litoral de Laguna & 3138 & 3919 & 3651 & & 46680 & & 41160 & & $50 \cdot 116$ \\
\hline 300 - Carbonifera & 12662 & 12589 & 12968 & & 319607 & & 319598 & & 312611 \\
\hline 301 - Iitoral Sul & 7527 & 6888 & 6. 922 & & 124894 & & 129.121 & & 129.117 \\
\hline 302 - Colonial Sul & 5965 & 5834 & 5955 & & $128 \quad 817$ & & 126321 & & 130.543 \\
\hline 303 - Campos de Lages & 7. 272 & 7. 244 & 7493 & 1 & 140112 & 1 & 124133 & 1 & 125720 \\
\hline 304 - Campos de Curitibanos & 12776 & 11890 & 12636 & 1 & 050953 & & 942460 & 1 & 022340 \\
\hline 305 - Colonial Rio do Peixe & 27706 & 25756 & 26063 & & 939895 & & 961204 & & 967.508 \\
\hline 306 - Colonial do Oeste & 53071 & 57.281 & 65.976 & 1 & $036 \cdot 168$ & 1 & 119400 & 1 & 331.601 \\
\hline 307 - Planalto de Canoinhas & 15671 & $15 \quad 153$ & 16060 & & 767214 & & 758205 & & $870 \cdot 227$ \\
\hline Santa Catarina & 207199 & $206 \quad 497$ & 215992 & 7 & $025 \quad 323$ & 6 & 877280 & 7 & 473.679 \\
\hline
\end{tabular}

FONTE: FIBGE, Censos Agropecuários de 1970,1975 e 1980.

(1) Exclusive os estabelecimentos sem declaração de ärea. 
outro lado, as nicrorregioes homogeneas 296-Colonial do Alto Itaja1, 299-Litoral de Laguna, 300-Carbonifera e 303-Campos de Lages apresentaram decrescinos na area nddia, enquanto as denais regioes năo afresentaram alterabos significativas. A area mediana apresenta, em geral, alteraģes muito pequenas. o que se destaca é o crescimento da area mediana na microrregiáo homogenea 293-Litoral de Itajal e sua dininuigato na microrregiăo homogenea 303-Campos de Lages.

o Indice de Gini e Indice de Theil so medidas de concentracko ou desigualdade, utilizadas para analisar a distribuicáo da posse da terra e a distribuia de renda. Tanto o Indice de Gini quanto o Indice de Theil sao nomeros puros, adimensionais, que varian entre zero e um. quanto mais proximo de zero, menor o grau de desigualdade e, contrariamente, quanto mais proximo da unidade, maior o grau de desigualdade. Uma apresentaco didatica dos fundamentos teoricos das medidas de desigualdade pode ser encontrada em HOFFMANN (1980, p. 271-300).

Por que utilizar duas medidas de desigualdade? Por que permitem observar aspectos diferentes da distribuiga da posse da terra e da distribuiquo de renda. Segundo DENSLOW JR * TYLER (1983, P.872), os Indices de Giri e de Theil sao complementares enquanto medidas de desigualdade, devido a suas sensibilidades diferentes. 0 Indice de Gini é relativanente mais senstuel a modificacos na faixa com alta densidade de frequencia. For sua vez, o lndice de Theil émais senslvel a modificapos na parte superior da distribuiga (HOFFMANN, 1989). 
TABELA 2 - Área média e mediana dos estabelecimentos agropecuärios em Santa Catarina e nas suas 16 microrregiōes homogēneas, em 1970, 1975 e 1980. (1)

\begin{tabular}{l|r|r|r|r|r|r}
\hline \multirow{2}{*}{$\begin{array}{c}\text { MICRORRGIAO } \\
\text { HOMOGENEA }\end{array}$} & \multicolumn{2}{c|}{ AREA MEDIA } & $(1)$ & \multicolumn{2}{c}{ AREA NEDIANA } & $(1)$ \\
\cline { 2 - 7 } & 1970 & 1975 & 1980 & 1970 & 1975 & 1980 \\
\hline 292 - Colonial de Joinville & 21,1 & 20,8 & 25,9 & 13,6 & 13,8 & 12,8 \\
293 - Litoral de Itajai & 19,1 & 23,6 & 36,2 & 9,7 & 12,3 & 15,6 \\
294 - Colonial de Blumenau & 19,1 & 18,3 & 23,3 & 12,4 & 11,9 & 12,2 \\
295 - Colonial Itajai Norte & 27,4 & 23,0 & 27,2 & 20,3 & 18,2 & 19,5 \\
296 - Colonial Alto Itajai & 27,1 & 23,1 & 24,4 & 17,3 & 14,7 & 14,5 \\
297 - Florianónolis & 18,6 & 17,7 & 21,9 & 6,6 & 6,5 & 6,5 \\
298 - Colonial Serrana & 36,0 & 35,3 & 36,6 & 22,2 & 21,4 & 21,3 \\
299 - Litoral de Laguna & 14,9 & 10,5 & 13,7 & 6,4 & 4,1 & 4,3 \\
300 - Carbonifera & 25,2 & 25,4 & 24,1 & 16,9 & 16,0 & 15,7 \\
301 - Iitoral Sul & 16,6 & 18,7 & 18,7 & 9,3 & 10,3 & 10,2 \\
302 - Colonial Sul & 21,6 & 21,7 & 21,9 & 14,3 & 13,6 & 13,3 \\
303 - Campos de Lages & 156,8 & 155,2 & 150,2 & 59,4 & 50,2 & 48,7 \\
304 - Campos de Curitibanos & 82,3 & 79,3 & 80,9 & 25,0 & 22,4 & 22,2 \\
305 - Colonial Rio do Peixe & 33,9 & 37,3 & 37,1 & 19,3 & 20,2 & 19,2 \\
306 - Colonial do Oeste & 19,5 & 19,5 & 20,2 & 12,6 & 12,3 & 11,7 \\
307 - Planalto de Canoinhas & 49,0 & 50,0 & 54,2 & 22,3 & 21,8 & 20,6 \\
- Santa Catarina & 33,9 & 33,3 & 34,6 & 15,2 & 14,3 & 14,0 \\
\hline
\end{tabular}

FONTE: Dados básicos dos Censos Agropecuärios de 1970, 1975 e 1980.

(1) Em percentual 
o Indice de Gini depende das diferengas entre a posse da terra de todos os pares de individuos. Nesta pesquisa, - Indice de Gini foi calculado levando-se em considerafáa desigualdade dentro dos estratos de area. Admitiu-se que dentro dos estratos de area con linite superior finito, a distribuifá tem funfolo de deneidade linear. Fessalte-se que em Santa catarina na ha estabelecinento agropecuario no tltimo estrato considerado pelo IBGE, que e acima de 100.000 ha.

Na tabela 3 sao apresentados os Indices de Gini de Theil da distribuica da posse da terra para Santa catarina e suas 16 microrregioes homogeneas. Aparentemente, em algumas microrregibes homogeneas, ha uma desconcentrafa fundiaria entre 1970 e 1975. Entretanto, no quinquenio seguinte, com excefao das microrregioes homogeneas 300-Carbonifera e 303-campos de Lages, evidencia-se o crescimento das medidas de desigualdade de distribuifa da posse da terra en Santa catarina.

Comparativamente a outras unidades da Federaca, Santa catarina apresenta indices menores de concentrafa fundiaria, com predominio da pequena fropriedade familiar. Embora tenha valores menores para os indices de desigualdade, a tendencia apresentada nos bltimos anos foi de aumento no grau de desigualdade de posse da terra (CEFA/SC,1984). Os dados da tabela 3 confirman esta observacto para as unidades de andise.

\footnotetext{
o Indice de Theil en Santa catarina passou de 0,693 en 1970 para 0,740 em 1980. Observa-se tamberl que, entre
} 
TABELA 3 - Indices de Gini e Theil da distribuiça de posse da terra dos estabelecimentos agropecuärios em Santa Cacarina e nas suas 16 microrregiōes homogéneas, em 1970,1975 e 1980 .

\begin{tabular}{l|c|c|c|c|c|c}
\hline \multirow{2}{*}{$\begin{array}{c}\text { MICRORRGIAO } \\
\text { HOMOGENEA }\end{array}$} & \multicolumn{3}{|c|}{ INDICE DE GINI } & \multicolumn{3}{c}{ INDICE DE THEIL } \\
\cline { 2 - 7 } & 1970 & 1975 & 1980 & 1970 & 1975 & 1980 \\
\hline \multirow{2}{*}{292 - Colonial de Joinville } & 0,522 & 0,519 & 0,655 & 0,535 & 0,477 & 0,751 \\
293 - Litoral de Itajai & 0,609 & 0,593 & 0,662 & 0,554 & 0,516 & 0,695 \\
294 - Colonial de Blumenau & 0,533 & 0,558 & 0,629 & 0,526 & 0,528 & 0,703 \\
295 - Colonial Itajai Norte & 0,444 & 0,429 & 0,471 & 0,341 & 0,298 & 0,408 \\
296 - Colonial Alto Itajai & 0,506 & 0,516 & 0,555 & 0,570 & 0,525 & 0,649 \\
297 - Florianopolis & 0,706 & 0,690 & 0,747 & 0,813 & 0,706 & 0,761 \\
298 - Colonial Serrana & 0,570 & 0,583 & 0,600 & 0,537 & 0,523 & 0,567 \\
299 - Litoral de Laguna & 0,635 & 0,646 & 0,714 & 0,603 & 0,638 & 0,772 \\
300 - Carbonifera & 0,497 & 0,527 & 0,518 & 0,390 & 0,414 & 0,417 \\
301 - Litoral Sul & 0,546 & 0,580 & 0,581 & 0,471 & 0,583 & 0,570 \\
302 - Colonial Sul & 0,480 & 0,508 & 0,521 & 0,354 & 0,377 & 0,422 \\
303 - Campos de Lages & 0,678 & 0,724 & 0,710 & 0,607 & 0,713 & 0,656 \\
304 - Campos de Curitibanos & 0,729 & 0,743 & 0,742 & 0,758 & 0,744 & 0,731 \\
305 - Colonial Rio do Peixe & 0,579 & 0,599 & 0,609 & 0,639 & 0,677 & 0,686 \\
306 - Colonial do Oeste & 0,509 & 0,516 & 0,565 & 0,488 & 0,505 & 0,702 \\
307 - Planalto de Canoinhas & 0,650 & 0,669 & 0,705 & 0,679 & 0,698 & 0,729 \\
- Santa Catarina & 0,648 & 0,659 & 0,680 & 0,691 & 0,708 & 0,738 \\
\hline
\end{tabular}

FONTE: Dados básicos dos Censos Agropecuärios de 1970, 1975 e 1980. 
1970 e 1980, O indice de Gini sempre cresce, enquanto o indice de Theil so diminui nas microrregibes homogeneas 297-Floniandpolis e 304-Campos de Curitibanos.

As microrregioes homogeneas 292-Colonial de Joinville, 293-Litoral de Itajai, 294-Colonial de Blumenau, 295Colonial de Itajal do Norte e 306-Colonial do Oeste Catarinense apresentavam baixo indice de desigualdade de distribuifa da posse da terra ate 1975. 0 aumento da desigualdade da distribuifo da posse da terra nestas regites, entre 1975 e 1980 , e bastante evidente. 0 Indice de Theil eleva-se de maneira significativa. Na microrregigo homogenea $293-L i t o r a l$ de Itajal, o fenomeno de concentrasa fundiaria esta associado a lavoura canavieira e as obras de drenagen havidas na regiáo (LAGO, 1988, F. 160$)$.

Ainda na faixa litoranea, o subprojeto Sombrio, orientado pela suDEsUL, possibilitou o aproveitamento economico de areas antes sujeitas a alagamentos frequentes (LAGO, 1988, $p$. 165). Entretanto, a sistematizagáo de varzeas nas microrregioses homogeneas 301-Litoral Sul Catarinense e 302-Colonial Sul Catarinense nao foi acompanhada de alteracos draticas na estrutura agraria, nos termos do ocorrido na microrregia homogerea $293-$ itoral de Itajal.

Outro fato interessante observado na transformado recente da estrutura fundiaria catarinense, diz respeito a reducádos indices de concentragato nas microrregioes homogeneas 303-Campos de Lages e 304-Campos de curitibanos. o planalto 
catarinense sempre se caracterizou pela estrutura fundidria mais concentrada e pelo predominio de grandes propriedades, a contrario das denais regioes do Estado. E provavel que a reducto do Indice de Theil nestas microrregioes homogeneas, entre 1975 e 1980, esteja ligada a movimento migratorio de agricultores japoneses para o planalto catarinense na década de 70 . A instalafo das colonias japonesas contribuiu inclusive para a alterafo no perfil agricola destas microrregioes homogeneas. A venda de grandes propriedades para implantaca de colonias pode ter influenciado a "desconcentracăo".

Os indicadores de desigualdade apresentados na tabela 4 reforgam as observacoes anteriores quanto ao aumento de desigualdade na distribuico da posse da terra nas microrregioes homogeneas de Santa Catarina. lle maneira sistematica, houve diminuica da area total ocupada pelos estabelecimentos menores do que a mediana (50-) e aumento da drea total ocupada pelos $5 \%$ maiores estabelecimentos ( $5+$ ). 
TABELA 4 - Porcentagem da ärea total correspondente aos $50 \%$ menores (50-) e aos $5 \%$
maiores (5+) estabelecimentos agropecuärios em Santa Catarina e nas suas
16 microrregiöes homogeneas, em 1970,1975 e 1980.

\begin{tabular}{|c|c|c|c|c|c|c|}
\hline \multirow{2}{*}{$\begin{array}{l}\text { MICRORREGIAOO } \\
\text { BOMOGENEA }\end{array}$} & \multicolumn{3}{|c|}{$50-$} & \multicolumn{3}{|c|}{$5+$} \\
\hline & 1970 & 1975 & 1980 & 1970 & 1975 & 1980 \\
\hline 292 - Colonial de Joinville & 17,6 & 17,2 & 11,4 & 32,8 & 30,7 & 47,8 \\
\hline 293 - Litoral de Itajai & 11,3 & 12,3 & 10,6 & 35,3 & 34,1 & 46,2 \\
\hline 294 - Colonial de Blumenau & 15,9 & 14,0 & 11,7 & 30,5 & 31,2 & 42,3 \\
\hline 295 - Colonial Itajai Norte & 21,5 & 21,0 & 20,0 & 25,6 & 20,3 & 27,5 \\
\hline 296 - Colonial Alto Itajai & 18,2 & 16,9 & 15,5 & 31,2 & 29,5 & 35,2 \\
\hline 297 - Florianopolis & 7,9 & 8,3 & 6,0 & 48,1 & 44,0 & 52,5 \\
\hline 298 - Colonial Serrana & 13,7 & 12,3 & 11,8 & 32,7 & 32,1 & 35,4 \\
\hline 299 - Litoral de Laguna & 11,3 & 11,0 & 8,7 & 39,5 & 41,4 & 52,7 \\
\hline 300 - Carbonifera & 16,4 & 14,8 & 15,4 & 23,3 & 25,3 & 25,1 \\
\hline 301 - Litoral Sul & 14,7 & 13,6 & 13,7 & 29,9 & 34,7 & 35,3 \\
\hline 302 - Colonial Sul & 17,7 & 15,7 & 15,4 & 22,5 & 23,2 & 25,5 \\
\hline 303 - Campos de Lages & 7,8 & 6,1 & 6,1 & 38,6 & 45,6 & 41,8 \\
\hline 304 - Campos de Curitibanos & 7,1 & 6,3 & 6,4 & 49,6 & 50,7 & 50,4 \\
\hline 305 - Colonial Rio do Peixe & 15,2 & 14,4 & 14,0 & 40,2 & 43,0 & 44,3 \\
\hline 306 - Colonial do Deste & 17,4 & 17,4 & 15,7 & 29,2 & 30,7 & 37,6 \\
\hline \multirow[b]{2}{*}{ Santa Catarina } & 11,1 & 9,8 & 8,3 & 44,4 & 45,3 & 50,0 \\
\hline & 11,4 & 10,8 & 10,1 & 45,6 & 46,5 & 49,7 \\
\hline
\end{tabular}

FONTE: Dados básicos dos Censos Agropecuários de 1970, 1975 e 1980. 


\title{
3.2 . As Transtormagoes no Kercado de Trabalho Agricola
}

\begin{abstract}
Un dos objetivos do trabalho $E$ estudar a modernizafó agricola en 1980 que, por sua vez, e reflexo das profundas alterabos ocoridas durante os anos 70 e provocadas pelo desenvolvimento capitalista recente. Como na maioria dos palses em desenvolvimento, estas transformacbes refletem maior urbanizafá, con uma rapida transferencia da populafáo economicamente ativa (PEA) da agropecuaria para os setores secundario e terciario. De fato, os dados do Censo Demografico informan que a participaço da agricultura na PEA do Brasil era de $54 \%$ em 1960, passou para $44 \%$ en 1970 e para menos de $30 \%$ em 1980. Na decada de 70 o Erasil passou a ser una sociedade urbana e industrial.
\end{abstract}

Este movimento en direcalo as setores náo agricolas tem reflexos sobre a renda faniliar, como enfatiza PASTORE et a 1 í $(1983)$. Em geral, o trabalho nos setores da inddstria, comercio e servicos executado sob relacoes mais formalizadas, com froteca da legislago trabalhista e melhor remuneracto, comparativamente a agropecuaria.

Santa Catarina na ficou a margem das mudanoas ocorridas na sooiedade brasileira. Conforme hatTos (1986), o Estado tem uma estrutura economica diversificada e que se alterou consideravelmente na decada de 70. A agricultura, que era responsavel for cerca de $40 \%$ da renda interna do Estado en 1960 , teve sua farticipacao reduzida para $15 \%$ en 1980 . A industria, ao contrario, elevou sua fartioipaco de $23 \%$ para $35 \%$, no mesmo 
periodo. o setor de servicos tamben apresentou acrescinos de participaquo relativa, passando de $36 \%$ para $50 \%$.

A modificaso estrutural registrada na economia catarinense pode ser analisada sob o ponto de vista da FEA, conforme tabela 5. Comparando a composiodo do pessoal ocupado em 1970 e 1980, por setor de atividade, e possivel perceber que a agricultura perde importancia frente aos demais. setores, neste Periodo, no Estado e nas microrregioes homogeneas. Nota-se que esta reduca foi mais acentuada nas microrregioes homogeneas 292Colonial de Itajal, 293-Litoral de ltajal, 294-Colonial de Blumenau e 297-Florianopolis.

Na regia do vale do ltajal, o modelo industrial desconcentrado e absorvedor de trabalho permite que, apesar do intenso processo de industrializagáo, a atividade agricola seja Freservada. Nessa regia, ao contrario do que acontece nos grandes centros industriais do pals, ha fabricas localizadas proximas da area rural (ou ate mesmo na propria drea rural). Essa industria absorve parte da năo-de-obra da pequena propriedade e reforfa a renda familiar. Nesta regia, e comum a mulher cuidar da atividade agropecuaria e o marido cou outros membros da famllia) exercerem atividades no setor industrial (FRANCO, 1989, F.36). O modelo industrial enoontrado no Vale do ltajal confere caracteristicas froprias a esta regiăo, que se destaca, no Estado, pela renda media elevada e pelo penor indice de desigualdade de distribuigéo de renda (HOFFHANN, 1987). A influencia da inddstria froxima da zona rural tamben e salientada POR SEYFERTH (1985): "Ao contrario de outras regioes de 
TABELA 5 - Participação relativa da População Economicamente Ativa, por setor de atividade, segundo as microrregiōes homogēneas de Santa Catarina, 1970 e 1980.(1)

\begin{tabular}{l|c|c|c|c|c|c}
\hline \multirow{2}{*}{$\begin{array}{c}\text { MICRORREGIAO } \\
\text { HOMOGENEA }\end{array}$} & \multicolumn{2}{|c|}{ AGRICULTURA } & \multicolumn{2}{c|}{ INDOSTRIA } & \multicolumn{2}{|c}{ SERVICOS } \\
\cline { 2 - 7 } & 1970 & 1980 & 1970 & 1980 & 1970 & 1980 \\
\hline 292 - Colonial de Joinville & 25 & 9 & 39 & 55 & 37 & 36 \\
293 - Litoral de Itajai & 28 & 12 & 24 & 35 & 47 & 53 \\
294 - Colonial de Blumenau & 33 & 13 & 35 & 53 & 32 & 34 \\
295 - Colonial Itajai Norte & 75 & 52 & 10 & 29 & 15 & 19 \\
296 - Colonial Alto Itajai & 67 & 52 & 13 & 20 & 20 & 28 \\
297 - Florianopolis & 23 & 9 & 19 & 24 & 57 & 67 \\
298 - Colonial Serrana & 76 & 57 & 9 & 22 & 15 & 21 \\
299 - Litoral de Laguna & 44 & 25 & 13 & 29 & 43 & 46 \\
300 - Carbonifera & 41 & 22 & 24 & 39 & 35 & 39 \\
301 - Litoral Sul & 63 & 35 & 13 & 29 & 24 & 36 \\
302 - Colonial Sul & 80 & 64 & 5 & 14 & 14 & 22 \\
303 - Campos de Lages & 34 & 23 & 28 & 32 & 39 & 45 \\
304 - Campos de Curitibanos & 68 & 49 & 15 & 22 & 18 & 28 \\
305 - Colonial Rio do Peixe & 65 & 43 & 14 & 27 & 21 & 30 \\
306 - Colonial do Deste & 78 & 62 & 7 & 13 & 15 & 24 \\
307 - Planalto de Canoinhas & 50 & 32 & 23 & 38 & 28 & 31 \\
- Santa Catarina & 51 & 32 & 20 & 32 & 29 & 36 \\
\hline
\end{tabular}

FONTE: Censos Demogräficos de 1970 e 1980.

(1) Em percentual 
colorizafúto do 5 ul do pais, onde a fragnentaga das propriedades ou o esgotamento das terras forgan a migraga para dreas de ocupago meis recente, a tendencia dos colonos do Itajal-mirim tem sido permanecer no campo como worker=eeasente roperarioscamponeses), sempre que posslvel, ou como assalariados da indistrian.

Com o auxilio dos dados dos Censos Agropecuarios, de 1970 , 1975 e 1980 , f fosstvel verificar as transformaceses no mercado de trabalho agrloola. O pessoal ocupado na agropecuaria, ao ser transformado em equivalentes-homem, fornece uma aproximafío satisfatoria do emprego no meio rural. Com a utilizacso do conceito de equivalente-homem, o numero de pessoas ocupadas e convertido en unidades de forca de trabalho, conforme metodologia adotada por hOFFMANN et a 1 i $(1985)$. As tabelas em anexo mostram a fora de trabalho na agropecuaria distribuida nas seguintes categorias: responsavel e membros nao remunerados da familia, empregados permanentes, empregados temporarios, parceiros e outra condicao e, finalmente, servifo de enfreitada.

Fode-se verificar que ocorre uma diminuiga do pessoal ocupado nas microrregibes homogeneas 292-Colonial de Joinville, 293-Litoral de Itajal, 294-Colonial de BIumenau e 297Florianopolis. Isso se deve, essencialmente, a reduga do trabalho familiar, categoria mais afetada neste periodo e nestas regioes. E provavel que a populagáo rural tenha sido atralda para empregos no setor de servigos e na industria, una vez que estas. regibes se destacam pela industrializacáo e pelo turismo. 
For outro lado, nas regioes en que ocorre aumento do pessoal ocufado, alen da elevacáo da nado-obra faniliar, observa-se tamben aumento no trabalho assalariado.

$$
\text { Torna-se necessario utilizar os dados do Censo }
$$

Agropecuario uma vez que o conceito da PEA lobtido do Censo Iiemografico) exclui de seu calculo as pessoas que exercem atividade agricola en tempo parcial. Na realidade, a PEA agricola subestima a forea de trabalho por excluir parte da máde-obra familiar, principal categoria ocupacional em Santa Catarina.(CEPA/SC, 1988a)

Ie acordo com o Censo Demografico de 1980, havia 418.249 pessoas economicamente ativas e 391.323 pessoas nao economicamente ativas, ligadas a atividade agropecudria em Santa Catarina. For sua vez, o Censo Agropecuario de 1980 registrava um total de 836.755 pessoas ocupadas na agropecuaria. A expressiva diferenfa entre os dados deve-se a diferenga nos conceitos adotados en cada Censo.

A pesquisa sobre pessoal ocupado, no censo Agropecuario, incluiu todas as pessoas, com ou sem remunerapas, que na data do Censo encontravantse prestando servifos ligados as atividades do estabelecimento. 0 censo lemografico, entretanto, classifica a populaqúo de 10 anos ou mais, quanto a condiga de atividade, em pessoas economicamente ativas e pessoas nao economicamente ativas. Aquelas pessoas que exerceram trabalho remunerado e trabalharam habitualmente pelo menos 15 horas semanais foram incluldas na PEA. Na pofulagăo näo-economicamente 
ativa foran incluidas aquelas pessoas que exercian atazeres domesticos no proprio lar ou que estudavam, entre outras situacies. Sabe-ee que na agricultura onde fredomina a ma-deobra familiar, a mulher (dona-de-casa) e os filhos dedican apenas parte do tempo ao trabalho nas atividades agricolas. Este é caso da agropecuaria catarinense.

o trabalho assalariado temporario tambem assume importancia em Santa catarina, devido a a amento de atividades que apresentam sazonalidade na demanda de trabalho, a exemplo da cultura de fumo. Por outro lado, a mecanizacáo parcial do processo produtivo, atingindo apenas algumas etapas do cultivo, tamben contribuiu para aumentar a sazonalidade na demanda de trabalho, levando os produtores a recorrerem com maior frequencia a contratagáo temporaria da máde-obra.

Com os dados de pessoal ocupado, transformados em equivalentes-homem, obteve-se a proporga de trabalho familiare a Froporfádo de trabalho assalariado em 1970,1975 e 1980 , conforme tabela 6 . Com estes dados e posslvel afirmar que, em Santa Catarina, a atividade agropecuaria ainda e conduzida de forma predominante pela familia. No entanto, observa-se o crescimento da participapa relativa do trabalho assalariado. Enfim, sáo registradas mudangas nas relagoes sociais de produpăo, com a diferenciagato mais nitida das classes sociais tipicas do capitalismo, com patróes émpregados. 
TABELA 6 - Participaça do trabalho familiar e do trabalho assalariado no total de equivalentes-homem empregados na agropecuäria, segundo as microrregiöes homogêneas de Santa Catarina, 1970, 1975 e 1980. (1)

\begin{tabular}{l|r|r|r|r|r|r}
\hline \multirow{2}{*}{$\begin{array}{c}\text { MICRORREGIAO } \\
\text { HOMOGENEA }\end{array}$} & \multicolumn{2}{c|}{ TRABALHO FAMILIAR } & \multicolumn{2}{c}{ TRABALHO ASSALARIADO } \\
\cline { 2 - 7 } & 1970 & 1975 & 1980 & 1970 & 1975 & 1980 \\
\hline 292 - Colonial de Joinville & 93 & 89 & 82 & 7 & 11 & 18 \\
293 - Litoral de Itajai & 87 & 84 & 68 & 13 & 16 & 32 \\
294 - Colonial de Blumenau & 94 & 95 & 91 & 6 & 5 & 9 \\
295 - Colonial Itajai Norte & 96 & 96 & 94 & 4 & 4 & 6 \\
296 - Colonial Alto Itajai & 88 & 95 & 93 & 12 & 5 & 7 \\
297 - Florianopolis & 91 & 92 & 82 & 9 & 8 & 18 \\
298 - Colonial Serrana & 92 & 96 & 91 & 8 & 4 & 9 \\
299 - Litoral de Laguna & 93 & 95 & 90 & 7 & 5 & 10 \\
300 - Carbonifera & 94 & 94 & 92 & 6 & 6 & 8 \\
301 - Litoral Sul & 89 & 90 & 89 & 11 & 10 & 11 \\
302 - Colonial Sul & 86 & 90 & 89 & 14 & 10 & 11 \\
303 - Campo de Lages & 76 & 75 & 73 & 24 & 15 & 27 \\
304 - Campos de Curitibanos & 80 & 82 & 73 & 20 & 18 & 27 \\
305 - Colonial Rio do Peixe & 92 & 91 & 86 & 8 & 9 & 14 \\
306 - Colonial do Oeste & 95 & 94 & 90 & 5 & 6 & 10 \\
307 - Planalto de Canoinhas & 85 & 83 & 80 & 15 & 17 & 20 \\
- Santa Catarina & 91 & 91 & 88 & 9 & 9 & 12 \\
\hline
\end{tabular}

- FO⿻上TE: Dados básicos dos Censos Agropecuärios de 1970, 1975 e 1980.

(1) En percentual 
Chana a atengáo o fato de a miororregiăo homogenea 296-Colonial do Alto Itajal apresentar crescimento da participacalo relativa do trabalho falliliar entre 1970 e 1980. Esta e uma tendencia oposta en relago as demais microrregibes homogeneas. Na microrregiso homogenea $296-C o l o n i a l$ do Alto Itajal houve um incremento significativo no cultivo de lavouras tipicamente conduzidas com trabalho faniliar, como fumo e cebola. Alem deste aspecto, cabe lembrar que nesta microrregiala, a industria textil tambem concorre para absorgo de trabalho, fazendo con que a mao-de-obra assalariada seja un fator relativamente escasso para a agricultura. 
3.3. Caracteristicas da Distribuiofo de Renda na Agropecuaria Catarinense em 1980

A renda agricola a que este trabalho se refere é rendimento medio mensal bruto declarado por ocasia do censo Demografico de 1980. Os dados foran fornecidos pelo IEGE atraves de tabulacoes especiais. Optou-se por estudar a distribuifódas pessoas conforme o rendimento familiar "per capita", para as famllias residentes em domiclios farticulares cujo chefe tem atividade principal na agropecudria, extracáo vegetal e pesca. De acordo com a bibliografia consultada, esta distribuigád a mais adequada para caracterizar a distribuifáo de renda na agropecuaria. Ná se dispoe de dados dessa natureza para outros anos, o que impede acompanhar as mudancas nesse tipo de distribuifüo.

Os dados fornecidos pelo lBGE contem o ntmero de familias, o numero de pessoas e o rendimento total para nove estratos de rendimento mensal familiar "per capita", cujos Iimites, en saldrios minimos, săo: ate $1 / 8$, mais de $1 / 8$ a $1 / 4$, mais de $1 / 4$ a $1 / 2$, mais de $1 / 2$ a $3 / 4$, mais de $3 / 4$ a 1 , mais de 1 a 2 , mais de 2 a 3 , nais de 3 a 5 , mais de 5 salarios minimos. E fornecido tamben o numero de familias e de pessoas sem rendimento.

O IBGE define "famlia" como sendo un conjunto de pessoas ligadas por lasos de parentescos ou de dependencia doméstica, que vivem no mesmo domiollio, ou pessoa que vive so em domiclio partioular. For sua vea, o rendimento familiar e definido como a soma dos rendimentos dos componentes das 
familias. Nas tabulaqoes especiais utilizadas, as familias foram classificadas conforme o rendimento familiar "per capita", segundo o conceito restrito de familia, no qual se considera o ndmero de pessoas, exclusive os pensionistas, empregados domesticos e parentes destes empregados.

Os dados do censo lemografico apresentam limitacoes quando utilizados na andise de distribuicao de renda. Entre as limitacós destacam-se a subestimacáo da renda total a a forma de publicaquo cinformabes apresentadas por estrato de renda). Uma discussáo ampla sobre as limitaofes dos dados e sobre as diversas distribuiqoes de renda que podem ser utilizadas para andise encontrada en HOFFMANN (1984), HOFFMANN K KAGEYAMA $(1986)$ e HOFFMANN $(1987)$.

Parte expressiva da agropecuária catarinense está diretamente ligada ao complexo agroindustrial, comoe o caso, tipicamente, dos produtores de fumo, dos avicultores e dos suinocultores. No caso das atividades ligadas a agroindastria, fica claro o pequeno poder de barganha dos agricultores frente aos setores oligopolizados da economia, e o estudo da distribuifa de renda se torna mais complicado. Nas condifos en que a froducto gerada na agropecuaria e valorizada e seu excedente apropriado pelas pessoas do setor industrial e/ou comercial, os dados referentes a pessoas ocupadas na agropecuaria subestiman a renda gerada no setor e nao permitem captar toda a desigualdade de distribuigäo dessa renda. Ressalte-se que o fato de os agricultores (se ná estiverem bem organizados) terem 
pequeno poder de barganha perante as industrias a jusante e a montante náo significa que a situagáo economica dos agricultores nato se torne melhor graoas a instalaga das agroindtstrias. Estas representam uma demanda mais estavel e facilitam a modernizagáo.

Embora admitindo a existercia de algumas
limitafos, os dados do censo Demografico de 1980 sa as
informafoes dispontveis que permiten caracterizar a distribuifao
de renda na agropecuaria catarinense, e atingir os demais
objetivos a que esta pesquisa se profoe.

A tabela 7 mostra o numerode familias residentes en domiclios particulares cujo chefe ten atividade principal na agropecuaria, o correspondente ntmero de pessoas e o tananho medio das famllias para as microrregioes homogeneas de Santa Catarina em 1980. No proximo capltulo, o ntmero de pessoas aqui apresentado sera utilizado como fator de ponderacaro na analise fatorial e na analise de regressao.

Entre as microrregios homogeneas de Santa Catarina, aquelas com menor ndmero de pessoas for familia sao: 292-Colonial de Joinville, 293-Litoral de Itajal, 294-Colonial de Elumenau e 303-Campos de Lages. Por outro lado, as microrregioes homogeneas 298-Colonial Serrana Catarinense, 302-Colonial Sul Catarinense e 30t-Colonial do oeste catarinense apresentam famllias mais numerosas. Com excegato da microrregialo homogenea 303-Campos de Lages, as microrregiöes homogeneas com familias menores situam-se na zona mais industrializada do Estado, ao passo que as microrregioes homogeneas com famllias mais numerosas 
TABELA $\dot{j}$ - Familias residentes em domicilios particulares cujo chefe tem atividade principal na agropecuária, extraçäo vegetal e pesca, nümero de pessoas e de pessoas por familia, segundo as microrregiöes homogèneas de Santa Catarina, etr 1980 .

\begin{tabular}{|c|c|c|c|c|}
\hline $\begin{array}{l}\text { MICRORREGIAO } \\
\text { HOMOGENEA }\end{array}$ & $\begin{array}{l}\text { NOMERO DE } \\
\text { FAMILIAS }\end{array}$ & $\begin{array}{l}\text { NOMERO DE } \\
\text { PESSOAS }\end{array}$ & $\begin{array}{r}\text { NOMERO } \\
\text { POR }\end{array}$ & $\begin{array}{l}\text { DE PESSOAS } \\
\text { FAMILIA }\end{array}$ \\
\hline 292 - Colonial de Joinville & 7380 & 34071 & & 4,62 \\
\hline 293 - Litoral de Itajai & 4446 & 21355 & & 4,80 \\
\hline 294 - Colonial de Blumenau & 10.558 & 51378 & & 4,87 \\
\hline 295 - Colonial Itajai Norte & 4.072 & 20.504 & t & 5,04 \\
\hline 296 - Colonial Alto Itajai & 13756 & 69932 & & 5,08 \\
\hline 297 - Florianōpolis & 7735 & 38660 & & 5,00 \\
\hline 298 - Colonial Serrana & 7528 & 39475 & & 5,24 \\
\hline 299 - Litoral de Laguna & 3893 & 19212 & & 4,94 \\
\hline 300 - Carbonifera & 11337 & 57993 & & 5,12 \\
\hline 301 - Litoral Sul & 6617 & 32.727 & 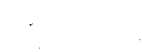 & 4,95 \\
\hline 302 - Colonial Sul & 6628 & $35 \cdot 361$ & & 5,34 \\
\hline 303 - Campos de Lages & 9.286 & 44279 & & 4,77 \\
\hline 304 - Campos de Curitibanos & $14: 548$ & 74737 & & 5,14 \\
\hline 305 - Colonial Rio do Peixe & 29055 & 143924 & & 4,95 \\
\hline 306 - Colonial do Oeste & 68381 & 356245 & & 5,21 \\
\hline 307 - Planal to de Canoinhas & 14752 & 74794 & . & 5,07 \\
\hline Santa Catarina & 219972 & 1114647 & & 5,07 \\
\hline
\end{tabular}

FONTE: Hoffmann, 1987. 
sao eminentemente agricolas.

Na tabela $B$ estao as medidas de tendencia central e de desigualdade de distribuiga da renda para as 16 microrregioes homogeneas de Santa Catarina, para o Estado, para a Regia Sul e fara o Brasil. A unidade de medida para a media e a mediana $\&$ o maior salario minimo (S.M.) vigente em agosto de 1980, que era de $\operatorname{Cr} \$ 4.149,60$. A renda media em Santa Catarina, en 1980 , era de 0,632 S.M., acima da renda media brasileira, porem abaixo da renda media da Regiáo Sul.

Cabe observar que a microrregiăo homogenea 305Colonial do Rio do Peixe apresenta a renda media mais elevada em Santa Catarina. A avicultura industrial e a principal atividade agropecuaria dessa microrregiáo homogenea. Em 1980, o prefo da carne de frango estava elevado e havia incentivo ds exportacos. Estes fatores poden ter contribuldo para elevaca da renda media.

Outras seis microrregioes homogeneas apresentam rendimento medio superior ao obtido no Estado: 292-Colonial de Joinville, 293-Litoral de Itaja1, 294-Colonial de Blumenau, 301Litoral sul Catarinense, 302-Colonial Sul catarinense e 303Campos de Lages. Nas microrregioes homogeneas 292-Colonial de Joinville, 293-Litoral de Itajai e 294-Colonial de Blumenau a renda media mais elevada pode estar associada a fato de membros da famllia trabalharem no setor industrial onde, historicamente, os salarios sao mais elevados do que na agropecuaria. Tal situaso pode contribuir para elevar a renda media familiar "per capita". 
TABELA 8 - Rendimento médio (M) e mediano (D), em salärios minimos, indices de Gini (G) e Theil (T), porcentagem da renda recebida pelos $50 \%$ mais pobres (50-), pelos $10 \%$ mais ricos $(10+)$ e pelos $5 \%$ mais ricos (5+), da distribuição de pessoas conforme o rendimento familiar "per capita", em 1980.

\begin{tabular}{|c|c|c|c|c|c|c|c|}
\hline $\begin{array}{c}\text { MICRORREGIXO } \\
\text { HOMOGENEA }\end{array}$ & $\mathbf{M}$ & D & G & $\mathbf{T}$ & $50-$ & $10+$ & $5+$ \\
\hline 292 - Colonial de Joinville. & 0,754 & 0,500 & 0,460 & 0,370 & 20,0 & 35,2 & 24,4 \\
\hline 293 - Litoral de Itajaí & 0,729 & 0,541 & 0,400 & 0,252 & 23,5 & 30,7 & 20,0 \\
\hline 294 - Colonial de Blumenau & 0,740 & 0,555 & 0,409 & 0,287 & 22,8 & 30,5 & 20,2 \\
\hline 295 - Colonial Itajai Norte & 0,483 & 0,393 & 0,369 & 0,207 & 24,8 & 26,6 & $\therefore 16,0$ \\
\hline 296 - Colonial Alto Itajaí & 0,578 & 0,408 & 0,445 & 0,325 & 20,7 & 33,7 & 22,4 \\
\hline 297 - Florianöpolis & 0,565 & 0,384 & 0,475 & 0,402 & 19,5 & 37,4 & 26,5 \\
\hline 298 - Colonial Serrana & 0,464 & 0,352 & 0,417 & 0,289 & 22,5 & 32,0 & 21,4 \\
\hline 299 - Litoral de Laguna & 0,464 & 0,346 & 0,411 & 0,285 & 22,8 & 31,7 & 21,2 \\
\hline 300 - Carbonifera & 0,614 & 0,455 & 0,441 & 0,331 & 21,1 & 33,5 & 22,8 \\
\hline 301 - Iitoral Sul & 0,676 & 0,460 & 0,473 & 0,386 & 19,7 & 37,4 & 26,5 \\
\hline 302 - Colonial Sul & 0,666 & 0,422 & 0,498 & 0,537 & 18,2 & 39,2 & 28,4 \\
\hline 303 - Campos de Lages & 0,758 & 0,392 & 0,571 & 0,532 & 15,2 & 48,3 & 36,5 \\
\hline 304 - Campos de Curitibanos & 0,568 & 0,292 & 0,579 & 0,588 & 15,0 & 49,4 & 39,0 \\
\hline 305 - Colonial Rio do Peixe & 0,831 & 0,484 & 0,531 & 0,444 & 16,3 & 42,0 & 29,7 \\
\hline 306 - Colonial do Oeste & 0,595 & 0,388 & 0,496 & 0,411 & 18,1 & 38,6 & 27,1 \\
\hline 307 - Planal to de Canoinhas & 0,499 & 0,310 & 0,509 & 0,456 & 17,8 & 41,1 & 29,8 \\
\hline Santa Catarina & 0,632 & 0,407 & 0,498 & 0,420 & 18,1 & 39,3 & 28,0 \\
\hline Regiäo Sul & 0,701 & 0,363 & 0,584 & 0,596 & 14,5 & 49,1 & 37,9 \\
\hline Brasil & 0,493 & 0,244 & 0,596 & 0,625 & 14,0 & 50,2 & 39,3 \\
\hline
\end{tabular}

FONTE: Hoffmann, 1987 
Verifica-se que a renda mediana em Santa catarina e superior a mediana obtida fara o Erasil e para a Regiao Sul. Entretanto, cabe observar que os valores da mediana fara as microrregibes homogeneas 298-Colonial Serrana Catarinense, 299Litoral de Laguna, 304-Campos de curitibanos e 307-Planalto de Canoinhas săo inferiores d mediana da Regiăo Sul.

I possivel perceber que as diferengas de renda nao sab muito marcantes entre as microrregioes homogeneas de Santa Catarina. A renda media mais elevada náo chega a ser o dobro da menor renda media. A renda mediana tambem na apresenta valores discrepantes entre as microrregioes homogeneas. $\mathbf{E}$ oportuno comparar con as diferengas de renda media entre as microrregioes homogeneas do Farana, conforme constatado for DEL GROSSI (1989): a renda media mais elevada (1,067 S.M. na microrregiao homogenea Campos de Ponta Grossal e cerca de tres vezes maior que a menor renda media $(0,293$ S.M. na microrregia homogenea Alto da Ribeira).

No que se refere ás medidas de desigualdade de distribuifto da renda, Santa Catarina apresenta indices relativamente menores, quando comparado com a Regialo Sul e o Brasil. Tanto o indice de Gini guanto o indice de Theil estao sempre abaixo de 0,600 .

A partir do ntmero de pessoas e da renda e posstvel calcular a frequencia relativa em cada estrato e a densidade de frequencia relativa (d.f.r.), utilizadas na construfto de histogramas, como os apresentados na figura 2. 
Neles, as familias sem rendimento foram agregadas no primeiro estrato (até $1 / 8$ de $S . M$. ) e fixou-se o limite superior de 20 S.M. para o ditimo estrato. Porem a densidade de frequencia relativa no tlimo estrato e tao pequena que rao chega a aparecer na escala utilizada. Este titimo estrato inclui apenas $0,65 \%$ da populapa analisada em Santa Catarina. Cabe observar que na microrregigo homogenea 296-Colonial do Alto ltajal nao ha nenhuma Pessoa neste estrato de renda, enquanto na microrregia homogenea 303-Campos de Lages cerca de $1,79 \%$ das pessoas fazem parte deste estrato. A titulo de ilustracao, apresentam-se os histogramas de Santa Catarina, e das microrregibes homogeneas 294-Colonial de Blumenau e 304-Campos de Curitibanos. Estas duas microrregioes homogeneas foram selecionadas por apresentarem, respectivamente, a maior e a menor renda mediana.

Em anexo sto apresentados os histogramas para as demais microrregioes homogeneas de Santa Catarina. Nestas figuras e posslvel perceber a assimetria forte e positiva para as microrregioes homogeneas 302-Colonial Sul Catarinense, 303-Campos de Lages, 304-Campos de Curitibanos, 305-Colonial do Rio do Peixe e 307-Planalto de Canoinhas.

Fara finalizar a caracterizaca da distribuifá de renda na agropecuaria catarinense cabe apresentar as medidas de pobreza. Para obtenca das nedidas de pobreza, alem da distribuigso de renda, e necessario escolher uma linha de pobreza. A determinaco da linha de pobreza e arbitraria, e as 

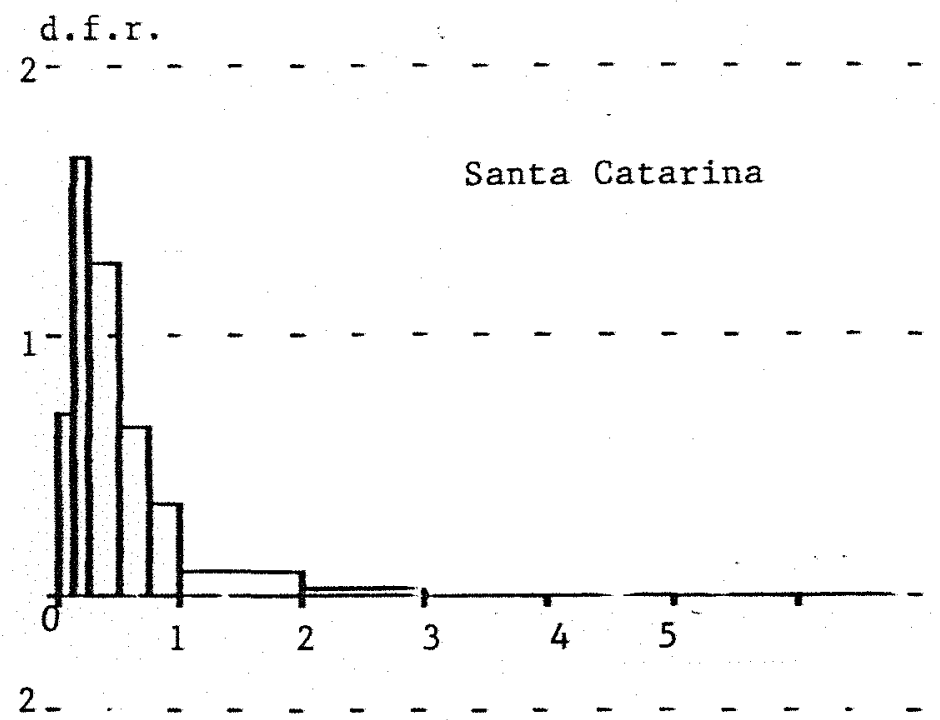

MRH 294-Colonial de Blumenau
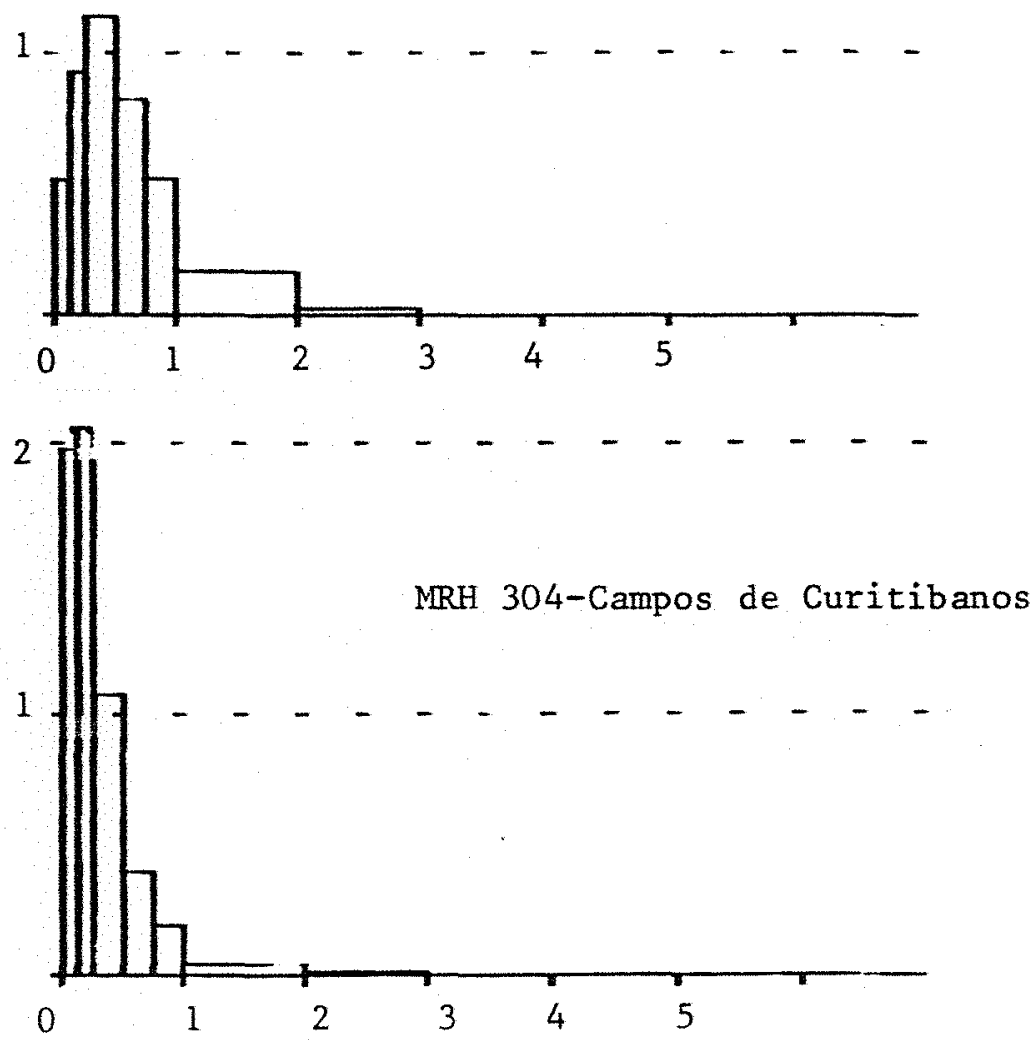

Figura 2. Histogramas da distribuigato de pessoas conforme seu rendimento familiar "per capita" em 1980. Santa Catarina, e microrregioes homogeneas 294-Colonial de Blumenau e 304-Campos de Curitibanos.(d.f.r. = densidade de frequencia relativa) 
Fessoas com renda igual ou inferior a esta linha serao consideradas pobres. A linha de pobrea adotada nesse trabalho é de 1/4 de saldrio minimo "per capita".

A primeira medida de pobreza e a proporaco de pobres (H), que indica a extensáo da pobreza na populacá. Dada uma populafó, na qual as pessoas estao ordenadas conforme valores crescentes de renda, a proporgád de pobres e obtida pela relacto entre o ndmero de pessoas com renda igual ou inferior a linha de pobreza e o numerototal de pessoas da populacáo.

Uma outra medida de pobreza e a razo de insuficiencia de renda (I), que representa a raza entre a insuficiencia de renda e montante de renda que seria recebida pelos individuos pobres se cada um recebesse um rendimento igual a linha de pobreza. Por definicao, a insuficiencia de renda de un pobre e a diferenca entre a linha de pobreza e a sua renda. A raza da insuficiencia de renda mede a intensidade da pobreza, porém é insenslvel a extensgo da pobreza.

o Indice de pobreza de sen el dado por:

$P=H[I+(1-1) G *]$

onde G* e o Indice de Gini da desigualdade da distribuigo de renda entre os pobres.

Observa-se que essa medida leva em considerafáa proporfo de fobres, a raza de insuficiencia de renda e a desigualdade de distribuigato de renda entre os pobres. Os Indices de pobreza de sen apresentados nesse trabalho foram obtidos 
incluindo, no calculo do indice de Gini entre pobres, estimativas de desidualdade dentro dos estratos.

A tabela 9 mostra as medidas de pobreza para as 16 microrregios homogeneas de Santa Catarina, para o Estado, para a Regiáo Sul e para o Erasil.

Em Santa Catarina, cerca de $30 \%$ das pessoas cujo chefe tem atividade principal na agropecuaria tem rendimento declarado inferior a $1 / 4$ de salario minimo "per capita". A proporfáo de pobres em Santa Catarina inferior ás registradas para a Regito Sul e para o Brasil. Entretanto, nas microrregioes homogeneas 304-Campos de Curitibanos e 307-Planalto de Canoinhas a proporago de pobres é superior a observada para a Regiao Sul.

A intensidade da pobreza (I) para o Estado e 0,356, isto e, seria necessario que a renda dos pobres crescesse em media $35,6 \%$ de 0,25 S.H. para que estas pessoas deixassem de ser consideradas pobres.

0 Indice de pobreza de Sen em Santa Catarina chega a ser inferior a metade do valor registrado para o Erasil. 0 destaque fica por conta das microrregioes homogeneas 292-colonial de Joinville, 293-Litoral de ltajal e 294-Colonial de Blumenau, que apresentam Indices de pobreza de Sen significativamente inferiores, quando comparadas com Santa Catarina, Regiao Sul Brasil. Por outro lado, as microrregioes homogeneas 304-Campos de Curitibanos e 307-Planalto de Canoinhas apresentan Indices de pobreza de Sen superiores aos observados para Santa Catarina e 
TABEIA 9 - Proporção de pobres (H), razāo de insuficiēncia de renda (I), indice de pobreza de Sen $(P)$, insuficiencia de renda como porcentagem da renda total (x) e distribuição dos pobres conforme o rendimento familiar "per capita", em $1980 .(1)$

\begin{tabular}{|c|c|c|c|c|c|}
\hline $\begin{array}{l}\text { MICRORREGIAO } \\
\text { HOMOGENEA }\end{array}$ & H & I & $\mathbf{P}$ & $\mathbf{r}(z)$ & $\begin{array}{l}7 \text { PESSOAS } \\
\text { POBRES }\end{array}$ \\
\hline 292 - Colonial de Joinville & 0,194 & 0,295 & 0,081 & 1,9 & 2,0 \\
\hline 293 - Litoral de Itajai & 0,140 & 0,257 & 0,051 & 1,2 & 0,9 \\
\hline 294 - Colonial de Blumenau & 0,151 & 0,294 & 0,063 & 1,5 & 2,4 \\
\hline 295 - Colonial Itajai Norte & 0,269 & 0,324 & 0,125 & 4,5 & 1,7 \\
\hline 296 - Colonial Alto Itajai & 0,278 & 0,324 & 0,126 & 3,9 & 5,9 \\
\hline 297 - Florianöpolis & 0,314 & 0,345 & 0,153 & 4,8 & 3,7 \\
\hline 298 - Colonial Serrana & 0,340 & 0,335 & 0,160 & 6,1 & 4,1 \\
\hline 299 - Litoral de Laguna & 0,344 & 0,309 & 0,147 & 5,7 & 2,0 \\
\hline 300 - Carbonifera & 0,249 & 0,350 & 0,124 & 3,5 & 4,4 \\
\hline 301 - Litoral Sul & 0,237 & 0,325 & 0,109 & 2,8 & 2,4 \\
\hline 302 - Colonial Sul & 0,265 & 0,345 & 0,127 & 3,4 & 2,9 \\
\hline 303 - Campos de Lages & 0,299 & 0,314 & 0,131 & 3,1 & 4,0 \\
\hline 304 - Campos de Curitibanos & 0,442 & 0,372 & 0,224 & 7,2 & 10,1 \\
\hline 305 - Colonial Rio do Peixe & 0,231 & 0,359 & 0,116 & 2,5 & 10,1 \\
\hline 306 - Colonial do Oeste & 0,316 & 0,374 & 0,163 & 5,0 & 34,2 \\
\hline 307 - Planalto de Canoinhas & 0,411 & 0,377 & 0,210 & 7,8 & 9,3 \\
\hline Santa Catarina & 0,294 & 0,356 & 0,145 & 4,2 & 100,0 \\
\hline Regiāo SuI & 0,345 & 0,370 & 0,176 & 4,6 & 11,8 \\
\hline Brasil & 0,513 & 0,437 & 0,300 & 11,4 & 100,0 \\
\hline
\end{tabular}

FONTE: Hoffmann, 1987.

(1) Adotando uma linha de pobreza de $1 / 4$ de salärio minimo. 
para a Regiáo Sul.

A quantidade de pessoas pobres è maior nas microrregibes homogeneas 304-Campos de curitibanos, 305-Colonial do Rio do Peixe, 306-Colonial do Deste Catarinense e 307Planalto de Canoinhas. Cerca de $2 / 3$ dos agricultores pobres de Santa Catarina encontram-se nestas microrregios homogeneas, as quais tambem corresponde o maior numero de pessoas de famllias cujo chefe tem atividade principal na agropecuaria. $E$ nas principais regiós agricolas que esta o maior numero de pobres.

Ainda com relagáo a distribuigáo de renda, cabe dizer ques teoricamente, espera-se uma relaobo direta entre a desigualdade de distribuifá da posse da terra a desigualdade de distribuifo de renda agricola, dada a importancia da terra como meio de producăo na agricultura. Em Santa Catarina, as microrregioes homogeneas 303-Campos de Lages, 304-Campos de Curitibanos, 305-Colonial do Rio do Peixe e 307-Planalto de Canoinhas apresentam Indice de Gini para distribuigato de renda superior ao Indice do Estado. Alids, as microrregiofes homogeneas 303-Campos de Lages e 304-Campos de Curitibanos apresentam rendas elevadas, foren acompanhadas dos maiores graus de desigualdade economica. Com excecáo da microrregiao homogenea 305-Colonial do Rio do Peixe, as demais apresentam tambem maior desigualdade na distribuiga da posse da terra. Alem deste aspecto, as Inicrorregioes homogeneas 304-Campos de Curitibanos e 307-Planalto de Canoinhas apresentam Indices elevados de pobreza, revelando piores condiges de vida para a maioria da populacóo. 
Afesar da existencia de regiós com grandes desigualdades sociais, como o planalto catarinense, as regioes agricolas do Vele do Itajal e do Litoral Norte se distinguem por apresentar uma situago oposta: tanto os indioes de desigualdade de distribuifo de renda ra agropecuaria, quanto as medidas de pobreza, apresentam valores baixos. o quese constata restas areas, alen da renda elevada que por sua vez caracteriza melhores condicos de vida, e a ausenoia de diferengas profundas entre aqueles que fermaneceram ra agropecuaria. E ofontuno enfatizar que as medidas de pobreza nas microrregiofs homogeneas 292-Colonial de Joinville, 293-Litoral de ltajai e 294-Colonial de Elumenau sán as menores medidas obtidas, comparativamente as demais microrregies homogeneas brasileiras (HOFFHAN, 1987). Näo resta duvida de que esta posiquo, incomum para o Brasil, e influenciada pela possibilidade (ou relativa facilidade) de pessoas de familias moradoras nas zonas rurais terem empregos na industria.

A distribuifo de renda mais equitativa tem bases na forma de ocupaco da terra. Ao contrario do encontrado para grande parte do territorio brasileiro, a formago historica da sooiedade catarinense baseou-se na pequena propriedade faniliar. A formaga estrutural decorrente deste processo contribui para uma menor desigualdade sooial e chega a influenciar os resultados obtidos no proxino cafitulo desta dissertagáo. 


\title{
4. HODERMIZAGAO E DISTRIBUIGAO DA RENDA MA AGROPECUARIA CATARIHEYSE EH 1980
}

\section{1. - A Modernizasáo na Agropecuaria Catarinense}

4. 1.1 - 0 Conceito de modernizasáo agricola e seus indicadores

\begin{abstract}
o desenvolvimento capitalista ra agricultura brasileira esta associado a mudangas na base tecnica e nas relafbes sociais de producto. 0 processo que aprofunda e consolida tais mudancas tem sido denominado genericamente de "modernizaca agrlcola". Neste trabalho, a modernizacao agrlcola representa o processo de mudanca tecnologica, que leva ao aumento da produtividade do trabalho e da terra, abrangendo inclusive as relafes sociais de producáo.
\end{abstract}

Apesar do termo "modernizacăo agricola" ser bastante difundido, sua definigato conceitual e um tanto complexa, por se tratar de um processo amplo e, Fossivelmente, multidimensional. Como existe uma diversidade de situages na produca agricola, existem, em consequencia, diversas formas de integrafá da agricultura ao desenvolvimento capitalista. For 
outro lado, admitindo-se que a modernizacáo agricola e um conceito complexo, sua operacionalizagáo requer a selefalo de aspectos e relaçes que se apresentem como sendo as mais relevantes dentro do contexto a ser analisado. Cabe esclarecer a relatividade da modernizagto, uma vez que pode ser abordada, em diferentes contextos, for diferentes indicadores. Esta caracteristica faz con que sua definica operacional assuma importancia consideravel dentro da pesquisa desenvolvida.

Para tornar operacional o conceito teorico de modernizacalo agricola, foram selecionados alguns indicadores, de acordo con a bibliografia consultada. Analisando as condifoes especificas da agropecuaria catarinense, foram identificados os aspectos mais relevantes para um estudo de modernizacalo agricola em Santa Catarina. A seleqáo mais adequada para o estudo proposto indicou os seguintes aspectos: uso de tecnologia, intensificaso da producăo agropecuaria e aumento da produtividade do trabalho, uso de capital financeiro e relapos sociais de produfáo.

- Uso de Tecnologia. Un dos aspectos mais marcantes das transformacbes recentes da agricultura brasileira em geral, e da agropecuaria catarinense em particular, foi a mudanca na base tecnica de producao. O padra tecrologico adotado permite que as inovacos introduzidas sejam aquelas de origem industrial e as que criem vinculos com omercado. Cada vez mais a agropecuária integra-se aos ramos industriais, tanto para aquisipgo de insumos incorporados ao processo produtivo, quanto para fornecer materia prima para processamento industrial. 


$$
\text { As transformagos tecnicas ocorridas na }
$$

agricultura se expressam pelo uso crescente de insumos que săo gastos durante a produgá, sem que seja posslvel reave-los na forma primitiva, tais como: agrotoxicos, fertilizantes e corretivos, sementes melhoradas, racos e medicamentos veterinarios. Mas a modernizacăo tambem se manifesta pela crescente importancia de bens de capital fixo, capazes de prestar sua contribuica em varios perlodos produtivos, como por exemplo, tratores, maquinas e implementos agrlcolas, construstes rurais mais especializadas, etc.

\section{- Intensificapáo da produpáo agropecuaria e aumento da}

produtividade do trabalho. Esta e uma das principais metas do desenvolvimento capitalista. A intensificaca da produsăo agropecuaria pode ser traduzida pelo aumento da produtividade, obtida pela ampliacto da capacidade produtiva, atraves do aumento da produca por unidade de area ou por unidade de trabalho.

- Uso de Capital Financeiro. Como mecanismo de incentivo a mudanca tecnologica, o credito agricola atua ampliando a venda de produtos e insumos industriais para a agropecuaria. Trata-se de articulafá da atividade agropecuaria com o capital financeiro, atraves da utilizacto de recursos crediticios.

- Relapoes Sociais de Producáo. Un dos principais indicadores do desenvolvimento das relagos capitalistas de produca na agricultura e dado pelas alteragós na composicáo da forfa de trabalho e indicada pelo aumento gradativo do trabalho assalariado. Nas sociedades de economia capitalista, abserva-se a 
presenga daqueles que sáo os proprietarios dos meios de produfáo e que vivem dos rendimentos que esta posse lhes propicia clucros, juros, renda da terra $),$ e a presenca daqueles cuja forma de sobrevivencia a venda de sua forqa de trabalho. Mo caso especifico de Santa catarina, dada a importancia que teve a colonizaclo por pequenas propriedades familiares, em grande parte do territorio, o agricultor e sua famllia sao, ao mesmo tempo, trabalhadores rurais e proprietarios dos meios de producáo. Em funfa desta peculiaridade, ou seja, do predominio do trabalho familiar, apenas duas variaveis foram selecionadas, indicando a Froporaco de trabalho familiar e a proporfóo de trabalho assalariado.

A seguir, sa apresentados os aspectos selecionados para a pesquisa emplrica e os indicadores de modernizaca a eles associados, precedidos dos respectivos simbolos. Maiores detalhes quanto a construgaco destes indicadores esta em anexo. A fonte dos dados para esta etapa foi o censo Agropecuario de 1980.

\section{a) Indicadores associados ao nso de tecnologia}

DEIM - Despesas com insumos modernos por area exploradaj

DEAC - Desfesas com adubos e corretivos for area exflorada;

DAHA - Despesas com defensivos agricolas por area explorada;

RHUA - Despesas com ragoes e medicamentos por unidade animal;

PPAF - Participaca da area com pastagens plantadas na area total com pastagens;

CAHA - Capacidade de armazenagem por area explorada; 
PTHA - Potencia de trator por area explorada;

VAHI - Valor dos bens em maquinas e instrumentos agrarios por area Explorada;

VABI - Valor dos bens en benfeitorias e instalagós por area Explorada;

CAUA - Investimentos em compra de animais por unidade animal;

b) Indicadores associados a intensificacao da producto agropecuaria e aumento da produtividade do trabalho

VAHA - Valor da produca agropecuaria por area explorada;

VAEH - Valor da produca agropecuaria por equivalente-homem;

ATAE - Area trabalhada por area exploravel;

LLVo - Litros de leite por vaca ordenhada;

\section{c) Indicadores associados ao uso de capital inanceiro}

FIHA - Financiamentos obtidos por area explorada;

FIEH - Financiamentos obtidos for equivalente-homem;

\section{d) Indicadores associados a relactes sociais de producao}

EHFA - Proporgao de trabalho familiar;

EHTA - Froporga de trabalho assalariado.

Os aspectos e indicadores selecionados, que constituem a operacionalizacáo do conceito de modernizacáo agricola, nao estáo desvinculados uns dos outros. Ao contrario, apresentam uma forte associaga entre s1. o padráo tecnologico adotado consolidou as relagós da agricultura com os demais setores da economia. For sua vez, a politica de credito rural foi agente fundamental no processo de modificacalo das condifoes da 
producto agropecuaria. Os: recursos crediticios - fartos e subsidiados - tinham, como exigencia institucional, que ser direcionados para a compra de insumos e de bens de capital para a agricultura. 0 uso de tecnologia e fator basico para a intensificagáo da producăo agropecudria e, nos casos onde ha utilizafáo de tecnologia capital-intensiva, esta e acompanhada de mudancas nas relapoes sociais de produgáo. os indicadores associados a relaqbes sociais de producáo somam $100 \%$ e representan o grau mais elevado de correlagáo. A inclusáo dos dois indicadores apenas reforoa a importancia do item d.

Quando alguns indicadores săo fortemente correlacionados, eles estao efetivamente "dizendo a mesma coisa". Entao, por que fazer uso de tantos indicadores? $r$ posslvel expressar a modernizacao agricola com um ntmero bem menor de indicadores? De um modo geral, pode-se afirmar que, quanto mais abstrata for a variavel (ou o conceito) que esta sendo estudada, tanto maior sera o numero de indicadores necessarios. Neste sentido, ao se admitir que o conceito de modernizacáo e amplo e multidimensional, necessario o uso de varios indicadores.

A existencia de correlagáo entre os indicadores inviabiliza a aplicacáco direta de regressa linear multipla para evidenciar as relaqóles entre modernizagáo e distribuigáo de renda na agropecuaria, por esbarrar no problema de multicolinearidade. De acordo com JoHNSTON (1986), quando as variaveis explicativas estao correlacionadas umas com as outras, torna-se praticamente imposslvel isolar influencias e obter estimativas precisas de 
seus efeitos relativos. Una proposta alternativa, que tem sido frequentemente usada, e fazer a regressgo linear mbltipla ná com as variaveis originais, mas cort fatores frincipais, obtidos de

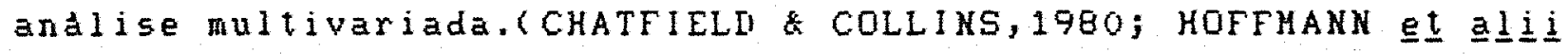
1985; TRONCOSO LEONE, 1988; DEL GROSSI, 1989; KIYUNA, 1989 E HOFFMANN \& KASSOUF, 1989).

\subsection{2 - obtenfaro de fatores pelo metodo dos componentes principais}

o tratamento estatistico adotado consiste em transformar un grupo original de variaveis correlacionadas em um novo conjunto de variaveis, perfeitamente ortogonais. As novas variaveis, em menor ntmero que as originais, sao denominadas componentes principais ou fatores. A reducto do conjunto original para um novo grupo de variaveis independentes entre si e o principal objetivo a ser alcansado. Tal redugáo favorecera o entendimento dos dados e simplificara analises e interpretafos subsequentes.

Para o presente estudo, adotou-se a andise fatorial pelo metodo dos componentes principais, partindo da matriz de correlacoes simples entre os 18 indicadores de modernizafá, sem alterar a diagonal principal da matriz de correlafós. Toda a analise, desde o calculo das correlacos, foi feita ponderando cada uma das 16 observactes ( 16 microrregibes homogeneas de Santa Catarina) pelo correspondente numero de pessoas de familias cujo chefe tem atividade principal na agropecuaria. A analise fatorial foi executada utilizando o 
pacote estatistico SAS/SYSTEH em microcomputador.

Nao se pretende fazer uma apresentaga formal do metodo adotado, mas apenas introduzir os elementos necessarios a compreensa dos resultados obtidos. As demonstragoes matematicas e outras implicacoses teoricas podem ser encontradas em HARMAN (1976), CHATFIELD \& COLLINS (1980) e JOHNSON \& WICHERN ( 1982$)$.

De maneira bastante sintetica, a aplicaca do método dos componentes principais envolve tres etapas distintas, que serao apresentadas com mais detalhes a seguir:

- obtengao da matriz de correlacies simples entre os indicadores de modernizapá;

- Extracko dos componentes principais, que possibilita a reducáo do ntmero de variaveis;

- Rotafao dos fatores iniciais e obtencao dos fatores terminais, que facilita a interpretaca dos fatores obtidos.

Basicamente, o problema a ser resolvido e, partindo de um conjunto de $n$ variaveis e de unidades de observafáo, encontrar um rovo grupo de variaveis ortogonais, cujas variancias decresfam sucessivamente.

Cabe observar que o metodo dos componentes principais enfatiza a explicaco da varianoia total das variaveis originais. Seu uso mais adequado onde todas as variaveis apresentam as mesmas unidades de medida. Portanto, torna-se necessario expressar as variaveis de forma padronizada, ou seja, transforma- 
las fara que tenham media zero e soma de quadrados igual a 1.

A matriz de variaveis transformadas, de dimensao $n$ $x$ m, ao ser pos-multiplicada por sua transposta, da origem a matriz $R$ de correlacós simples entre variaveis, de dimensăo $n x$ n, sobre a qual pode ser feita a analise fatorial pelo metodo dos componentes principais. A bibliografia consultada cita como usual a extrafáo de componentes principais a partir da matriz de correlacbes simples.

A cada componente principal corresponde uma raiz caracterlstica da matriz R. Caso a matriz R das correlapos simples seja na-singular, tera tantas ralzes caracterlsticas quantas forem as variácis.

E Preciso lembrar que os componentes principais sao combinacbes lineares das $n$ variaveis originais e arranjados em ordem decrescente de importancia no que diz respeito a sua contribuifo para explicar a variancia total dos dados originais. Mais especificamente, o primeiro componente principal e a combinafáo linear das variaveis originais que pode explicar individualmente a maxima parcela da variancia total; o segundo componente principal a a segunda melhor combinapto, que explica o maximo da parcela restante, com a condiáa de ser ortogonal a Frimeiro; e assim por diante, ate a variancia total ser explicada. A soma das variancias de todos os $n$ componentes principais e igual a soma da variancia das variaveis originais. Enfim, o princlpio matematico pelo qual se orienta a formaca dos componentes principais e que estes sao obtidos de forma a 
maximizar a porcentagem da variancia total explicada pelo fator sucessivo, dada a incluséco dos componentes precedentes e mantendo sua ortogonalidade.

Uma das vantagens do metodo dos componentes principais e reduzir o conjunto de dados originais. Se os primeiros componentes explicam a maior parteda variancia destes dados, podem ser utilizados em analises posteriores. Estes fatores passam a formar un grupo menor do que o numero de variaveis que the deram origem, facilitando a analise.

Qual a proporqa adequada da variancia total a ser explicada? Qual o ndmero de componentes que deve ser retido? Esta e uma decisgo que vem acompanhada de certa dose de arbitrariedade, uma vez que nao existem regras fixas para toma1a. A referencia encontrada e de se desprezar as ralzes caracteristicas menores do que 1. Os pacotes estatisticos para computador frequentemente adotam a convenga de determinar o numero de fatores igual ao ntmero de ralzes caracteristicas maiores do que 1 , caso a analise fatorial seja feita a partir da matriz de correlacoes.

Caso a maior parte da variancia total dos dados (por exemplo, un valor superior a $75 \%$ ) possa ser atribulda ao conjunto dos dois ou tres primeiros componentes, entao este conjunto pode "substituir" os dados originais sem muita perda de informacto.

Apos a rotacto ortogonal, os componentes principais ou fatores iniciais sao transformados de modo a gerar novos 
fatores independentes. Estes, por sua vez, continuam a explicar a mesma proporga da variancia total, mas tem a peculiaridade de estarem mais estritamente ligados a grupos particulares de variaveis. Esta etapa tem como finalidade alcancar uma interpretacto melhor dos fatores obtidos. Para o presente estudo, para a rotago ortogonal utilizou-se o criterio VARIMAX.

As cargas fatoriais sao os coeficientes de regressao linear entre cada fator e as variaveis transformadas, e medem a correlaqáo entre cada fator e estas variaveis. A andise das cargas fatoriais pode sedar atraves das colunas (que representam os fatores) ou atraves das linhas (que representam as variaveis).

A soma dos quadrados das cargas fatoriais das $\mathbf{n}$

variaveis en um fator e igual ao valor da raiz caracteristica associada ao fator. Por outro lado, o resultado do quociente da raiz caracterlstica pelo ntmero de variaveis fornece a proporfáo da variancia explicada pelo fator. Passando a analisar em sentido horizontal (observando-se as linhas), a soma dos quadrados das cargas fatoriais representa a contribuiga dos fatores para a explicacáo da variancia total de cada variavel, ou "comunalidade" da variáel.

Se fossem utilizados todos os $n$ componentes principais que normalmente possivel extrair da matriz $n$ x $n$ de correlafoes, seriam obtidos $\mathbf{n}$ fatores que explicariam totalmente a variancia de cada variavel. 
Entretanto, um dos objetivos de se utilizar a analise fatorial pelo metodo dos componentes prinoipais é reduzir - conjunto de dados originais. Normalmente, trabalha-se com poucos fatores, ou seja, o numero de fatores e menor do que o ndmero de variaveis. Portanto, a proporoáda variancia explicada pelos fatores, que a comualidade da varidvel, sera um numero menor do que a unidade. Quanto mais proxima de 1, maior é a contribuifá dos fatores para a variancia total da variavel considerada.

Apos a obtencto dos fatores, necessario identifica-los. For vezes, esta identificacáo e um tanto subjetiva e significa atribuir um nome a cada fator. Na pratica, nem sempre el uma tarefa facil "rotular" os fatores obtidos. A denominaga, forem, deve fornecer um indicativo das variális importantes, que entram na composiogo do fator. Como variaveis importantes podem ser definidas aquelas cujo coeficiente de correlafso com o fator e um valor proximo ou superior a 0,6 . 0s fatores podem ser analisados tamben de acordo com as unidades de observacá, que podem ser classificadas de acordo com o valor e o sinal dos escores fatoriais. Dessa maneira e possivel agrupar as unidades de observafáo e obter regionalizaobes. Para a regionalizacalo, alem dos escores fatoriais, seráo consideradas as principais caracteristicas socio-economicas das microrregioes homogeneas. 


\subsection{Resultados da Analise Fatorial}

\subsubsection{Os fatores de modernizacáo}

os fatores de modernizacto săo obtidos como resultado da analise fatorial a que foram submetidos os 18 indicadores selecionados para opresente estudo. Conforme ja descrito anteriormente, apds a obtengăo da matriz de correlafbes, o passo seguinte é decidir quantos fatores seráo retidos para uma rotaflo ortogonal. Neste fasso, leva-se em considerafá as maiores ralzes caracterlsticas. A matriz $18 \times 18$ das correlafos contem 3 ralzes caracteristicas maiores do que 2 , correspondendo a 83,91 da variancia total dos dados originais. Optou-se por extrair apenas os 3 primeiros fatores para facilitar a interpretapáo a representapao grafica.

Apos a rotagáo ortogonal, obtem-se a matriz de cargas fatoriais, apresentada na tabela 10 . Na ditima coluna da referida tabela estao as comunalidades, ou seja, a proporfac da variancia de cada indicador que explicada pelos tres fatores. Analisando-se no sentido das linhas, os tres fatores explicam uma grande proporáa da variancia dos indicadores selecionados para esta andise. Na tltima linha esta as proporcós da variancia total explicada pelos fatores. Ao primeiro fator corresponde individualmente a maxima parcela da variancia total $(32,23 \%)$. As contribuicoes dos outros fatores guardam entre si uma diferenca pequena $(26,20 \%$ e $25,48 \%)$. Em conjunto, os tres fatores explicam 83,91 * da variancia total dos dados originais. Estes resultados podem ser considerados satisfatorios. 
A etapa seguinte consiste em interpretar os fatores de modernizaso resultantes da analise fatorial, que pode ser definida como uma identificago dos indicadores com os quais cada fator apresente correlacăo elevada.

o primeiro fator (F1) apresenta correlago forte e positiva com os seguintes indicadores:

- EHFA = Froporga de trabalho familiar;

- LLVO = Litros de leite por vaca ordenhada;

- PPAP = Participaqá da drea con pastagens plantadas na area total com pastagens;

- VABI = Valor das benfeitorias e instalagos por area explorada;

- ATAE = Area trabalhada por area exploravel;

- CAHA = Capacidade de armazenagem por area explorada;

- PAHA = Valor da produgáo agropecuaria por area exploradaj

Apresenta correlagdo elevada e negativa com:

- EHTA = Proporgá de trabalho assalariado;

- FIEH = Financiamentos obtidos por equivalente-homem.

A nivel tedrico, e possivel interpretar F1 relacionando-o com a intensificacáo da exploracăo na propriedade familiar. A nivel operacional, distingue-se a pecuaria leiteira (LLUO e PPAP), a intensificagáo do uso da terra (ATAE e PAHA) e adofáo de tecnologia associada a bens de capital (VABI e CAHA). Cabe destacar que praticamente todo o peso dos indicadores associados as relaqoes sociais de producáo (EHFA E EHTA) incide 
TABELA 10 - Cargas dos fatores principais, comunalidade e proporçäo da variāncia total atribuida a cada fator sucessivo, apös a rotaça ortogonal dos 3 fatores principais da matriz $18 \times 18$ das correlacóes simples, com ponderacāo pelo numero de pessoas de familias cujo chefe tem ativida. de principal na agropecuäria, nas 16 microrregiōes homogēneas de San ta Catarina, eu 1980.

\begin{tabular}{|c|c|c|c|c|c|}
\hline & \multirow{2}{*}{$\begin{array}{c}\text { INDICADORES } \\
\text { DE } \\
\text { MODERNIZACAO }\end{array}$} & \multicolumn{3}{|c|}{ CARGA DOS FATORES PRINCIPAIS } & \multirow{2}{*}{ COMUNALIDADE } \\
\hline & & F 1 & F 2 & F 3 & \\
\hline EHFA & & 0,97519 & $-0,00047$ & 0,11826 & 0,96497 \\
\hline EBTA & & $-0,97519$ & 0,00047 & $-0,11826$ & 0,96497 \\
\hline Levo & & 0,59334 & 0,50797 & 0,27031 & 0,68315 \\
\hline VABI & & 0,67769 & 0,58346 & 0,32743 & 0,90690 \\
\hline PPAP & & 0,68187 & 0,37534 & 0,23266 & 0,65995 \\
\hline ATAE & & 0,68881 & 0,44617 & 0,40190 & 0,83504 \\
\hline CAHA & & 0,84777 & $-0,01730$ & 0,40303 & 0,88144 \\
\hline PAEH & - & $-0,06401$ & 0,84160 & $-0,18016$ & 0,74484 \\
\hline RMUA & & 0,25612 & 0,93427 & $-0,09936$ & 0,94833 \\
\hline CAUA & & $-0,04461$ & 0,70792 & $-0,28179$ & 0,58253 \\
\hline EIHA & & 0,13573 & 0,71343 & 0,56421 & 0,84573 \\
\hline FIEH & & $-0,66212$ & 0,61382 & 0,25235 & 0,87885 \\
\hline DEIM & • & 0,40386 & $-0,02961$ & 0,87019 & 0,92121 \\
\hline VAMI & & 0,42409 & 0,45081 & 0,63638 & 0,78806 \\
\hline PTEA & & 0,16539 & 0,00645 & 0,94126 & 0,91337 \\
\hline DEAC & & 0,43635 & $-0,24004$ & 0,74755 & 0,80684 \\
\hline DAHA & & $-0,03315$ & $-0,07193$ & 0,90567 & 0,82652 \\
\hline PAHA & $\cdot$ & 0,58351 & 0,73589 & 0,26164 & 0,95046 \\
\hline PROPOF & CĀO DA VARIĀNC & 32,23 & 26,20 & 25,48 & 83,91 \\
\hline
\end{tabular}


sobre F1. Devido a dependencia entre proporoáo de trabalho familiar e proporfáo de trabalho assalariado as cargas fatoriais sao simetricas.

Pode-se concluir que este fator reflete uma agrofecuaria onde o trabalho familiar tem grande importancia. Nas regibes onde se desenvolve esta agropecuaria, as relacoes sociais de Frodugato nao se "modernizaram", como mostra o sinal negativo associado ao indicador de trabalho assalariado. Con estes resultados constata-se que em santa catarina a modernizacao agricola ná e contraditoria com a grande importancia da mádeobra familiar.

0 segundo fator $(F 2)$ esta associado de maneira forte e positiva con os seguintes indicadores:

- FIHA = Financiamentos obtidos por area explorada;

- FIEH = Financiamentos obtidos por equivalente-homem;

- CAUA = Investimentos em compra de animais por unidade animal;

- RHUA = Despesas com ractes e medicamentos por unidade animal;

- PAHA = Valor da producto agropecuaria por area explorada;

- PAEH = Valor da producao agropecuaria por equivalentehomem;

- VABI = Valor dos bens em benfeitorias e instalafoes por area explorada.

Este fator esta mais diretamente relacionado com a utilizaga de credito rural, uma vez que os dois indicadores 
associados ao uso de capital financeiro estáo incidindo sobre F2. A intensificagáo da producáo agropecuaria e o aumento da produtividade do trabalho tamben sag caracteristicas marcantes das regiöes que apresentam valores positivos e elevados para f2.

De fato, a formago de plantel de alto valor zooteonico, o consumo de racos e outros produtos veterinários, investimento em bens de capital para instalages adequadas, sao fatores que caracterizam uma criacăo modernizada. Estes fatores tiveram sua aquisigáf facilitada coma utilizacá de capital financeiro. A avicultura de corte e a suinocultura sáo representantes tipicas deste tipo de criaca e constituem atividades de grande relevancia para Santa Catarina. A intensificafáo da agropecuaria pode estar ligada tambem a lavouras com elevada produtividade for unidade de terra e de trabalho, como e o caso da cana-de-aftcar.

o terceiro fator ( $F 3$ ) apresenta correlacáo alta e positiva com:

- DEIM = Despesas com insumos modernos por area explorada;

- DEAC = Despesas com adubos e corretivos por area explorada;

- IAHA = Despesas com defensivos agricolas por area explorada;

- FTHA = Fotencia de trator for area explorada;

- VAMI = Valor de maquinas e instrumentos agrarios por area explorada.

Este fator esta ligado de forma mais especifica ao 
uso de tecnologia moderna, e a disponibilidade de bens de capital, principalmente tratores e maquinas agricolas. Indica uma agricultura que utiliza com mais intensidade as tecnicas modernas de producto. 0 padráo tecnologico em F3 e distinto daquele encontrado para F1, pelo aspecto da maior utilizaoa de bens de consumo intermediario e de capital pela agricultura. As microrregioes homogeneas com escores fatoriais elevados e positivos para $F 3$ sao aquelas onde se pratica uma agricultura absorvedora de insumos agroquimicos e onde ha enfase na mecanizafáo.

Em sintese, o resultado da analise fatorial com 18 indicadores de modernizaca para as 16 microrregibes homogeneas de Santa Catarina, em 1980, permite a obtenca de tres fatores Principais, que poden ser identificados como segue:

Fator 1 (F1) - Propriedade Faniliar;

Fator 2(F2) - Criacăo Kodernizada e Financiamentos;

Fator $3(\mathrm{~F} 3)$ - Uso Intensivo de Mecanizaca e Insumos Modernos. 


\subsubsection{A Caracterizạáo Regional}

Apds a etapa de obtencto e identificafódos fatores so calculados os "valores dos fatores" para cada microrregizo homogenea. Com este procedimento e possivel classificar as microrregioes homogeneas segundo o grau de modernizaca e agrufa-las de acordo com este criterio.

Os valores sao calculados de maneira que cada fator seja uma variavel reduzida, com media zero e variancia igual a 1. Dessa forma, valores positivos e negativos fara um fator representam, respectivamente, acordo e oposifao as caracterlsticas do fator. Valores intermediarios e proximos de zero significam neutralidade en reląăo ao fator.

Os valores dos tres fatores principais em cada uma das 16 unidades de observaquo estáo na tabela 11. Considerando as combinafoes dos tres fatores dois a dois, e possivel representar a posigăo das microrregióes homogeneas em relacáo as caracteristicas dominantes de cada fator.

Na Figura 3 encontra-se a combinacuo de F1Fropriedade Familiar com F2-Criaglo Modernizada e Financiamentos. As microrregiós homogeneas 305-Colonial do Rio do Peixe e 306-Colonial do Deste catarinense ocupam o frimeiro quadrante e tem, como principal caracterlstica, o predominio da propriedade familiar, voltada para oriago modernizada e absorvedora de capital financeiro. 
TABELA il - Valores dos trēs fatores de modernizaçāo, segundo as microrregiōes homogêneas de Santa Catarina, em 1980.

\begin{tabular}{|c|c|c|c|c|}
\hline \multirow{2}{*}{$\begin{array}{l}\text { MICRORREGIĀO } \\
\text { HOMOGENEA }\end{array}$} & \multicolumn{4}{|c|}{ FATORES DE MODERNIZACÃO } \\
\hline & F 1 & & F 2 & F 3 \\
\hline 292 - Colonial de Joinville & $-0,55048$ & & 0,55201 & 0,09257 \\
\hline 293 - Litoral de Itajai & $-3,68026$ & & 1,63296 & 2,92826 \\
\hline 294 - Colonial de Blumenau & 0,75503 & - & 0,85394 & $-0,89493$ \\
\hline 295 - Colonial Irajai Norte & 1,12001 & - & 1,22514 & $-0,35719$ \\
\hline 296 - Colonial Alto Itajai & 0,88689 & - & 1,29730 & 0,79143 \\
\hline 297 - Florianopolis & $-0,87653$ & . & 0,35376 & $-0,63713$ \\
\hline 298 - Colonial Serrana & 0,43228 & - & 1,63901 & $-1,15059$ \\
\hline 299 - Litoral de Laguna & 0,23112 & - & 0,66890 & $-2,03164$ \\
\hline 300 - Carbonífera & 0,81602 & - & 0,55525 & $-0,18835$ \\
\hline 301 - Litoral Sul & $-0,18313$ & - & 0,81758 & $\quad 1,17491$ \\
\hline 302 - Colonial Sul & $-0,03743$ & - & 1,12125 & 3,11867 \\
\hline 303 - Campos de Lages & $-1,80542$ & - & 0,89162 & $-1,43493$ \\
\hline 304 - Campos de Curitibanos & $-1,66884$ & - & 0,61868 & $-0,67063$ \\
\hline 305 - Colonial Rio do Peixe & $-0,04397$ & & 1,49031 & $-0,72736$ \\
\hline 306 - Colonial do Oeste & 0,63226 & & 0,60272 & 0,29280 \\
\hline 307 - Planal to de Canoinhas & $-0,91318$ & - & 1,00238 & 0,23504 \\
\hline
\end{tabular}


Na Figura 4 observa-se a combinaqa de F1-Fropriedade Familiar com F3-Uso Intensivo de Insumos Modernos e Mecanizaglo. Nas microrregioes homogeneas 296-Colonial do Alto Itajal e 306Colonial do Oeste Catarinense, posicionadas no primeiro quadrante, ha absorgéde tecrologia (insumos modernos), porem o uso de moto-mecanizaga e limitado pelas caracterlsticas do relevo e pelo tamanho das propriedades. Cabe lembrar que na microrregiao homogenea $296-C o l o n i a l$ do Alto ltajal predomina o uso de microtratores.

Analisando as posicoles ocupadas pelas microrregioes homogeneas atraves da combinaga dos valores dos fatores, e posslvel perceber que a modernizacao agricola, enquanto processo de transformaga, nao ocorre de maneira analoga nas diversas regioes do Estado. Assim, regioes com um alto grau de modernizaca agrlcola, como o verificado para as microrregibes homogeneas 293-Litoral de Itajal, 302-Colonial Sul Catarinense e 305-Colonial do Rio do Peixe, convivem com areas extremamente atrasadas, como o caso da microrregiáo homogenea 299-Litoral de Laguna. 


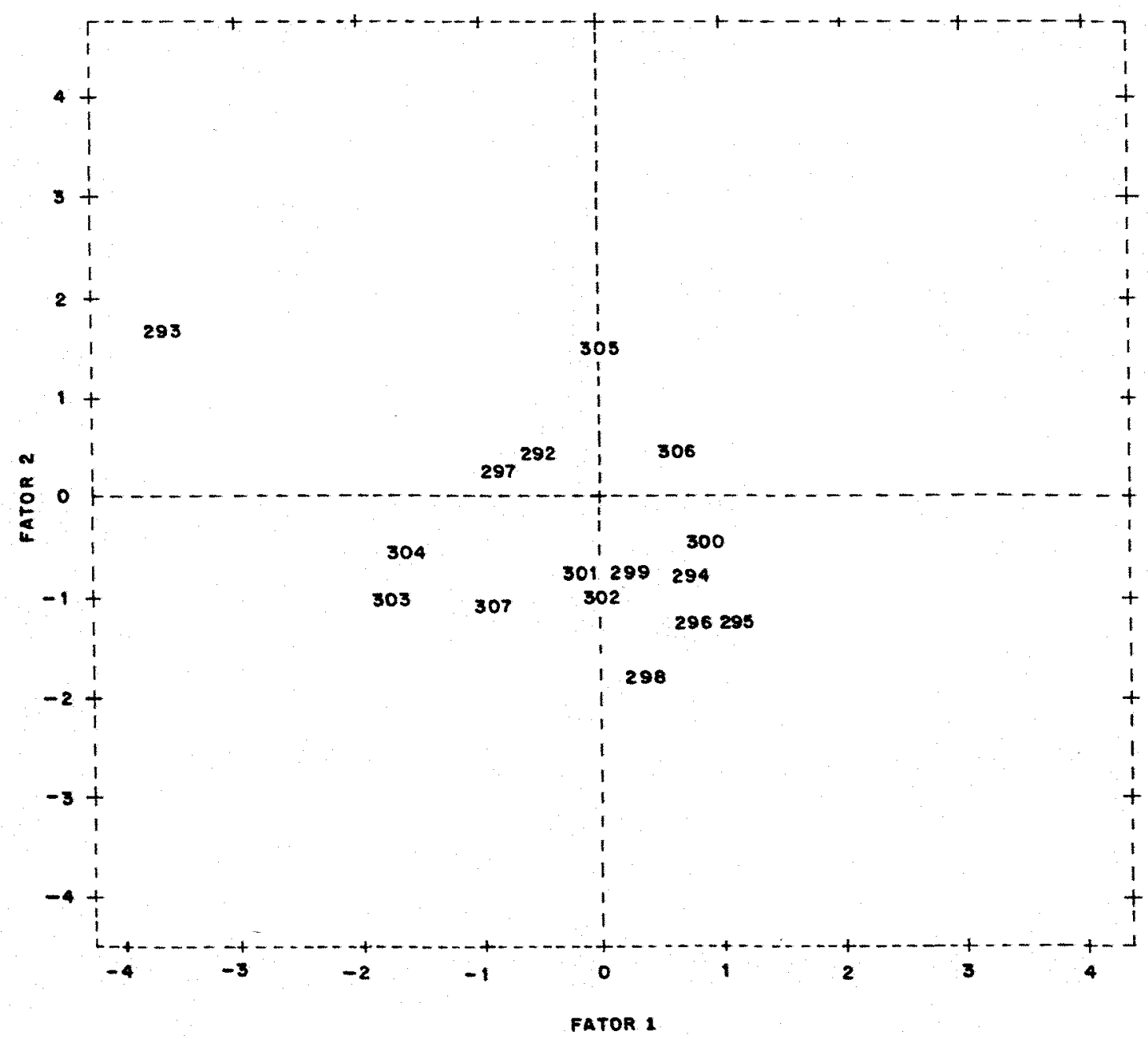

Figura 3. Representagăo grafica da combinagáo dos valores dos fatores FI - Propriedade Familiar e F2 - Criacó Hodernizada e Financiamentos, segundo as microrregiöes homogeneas de Santa Catarina, em 1980. 


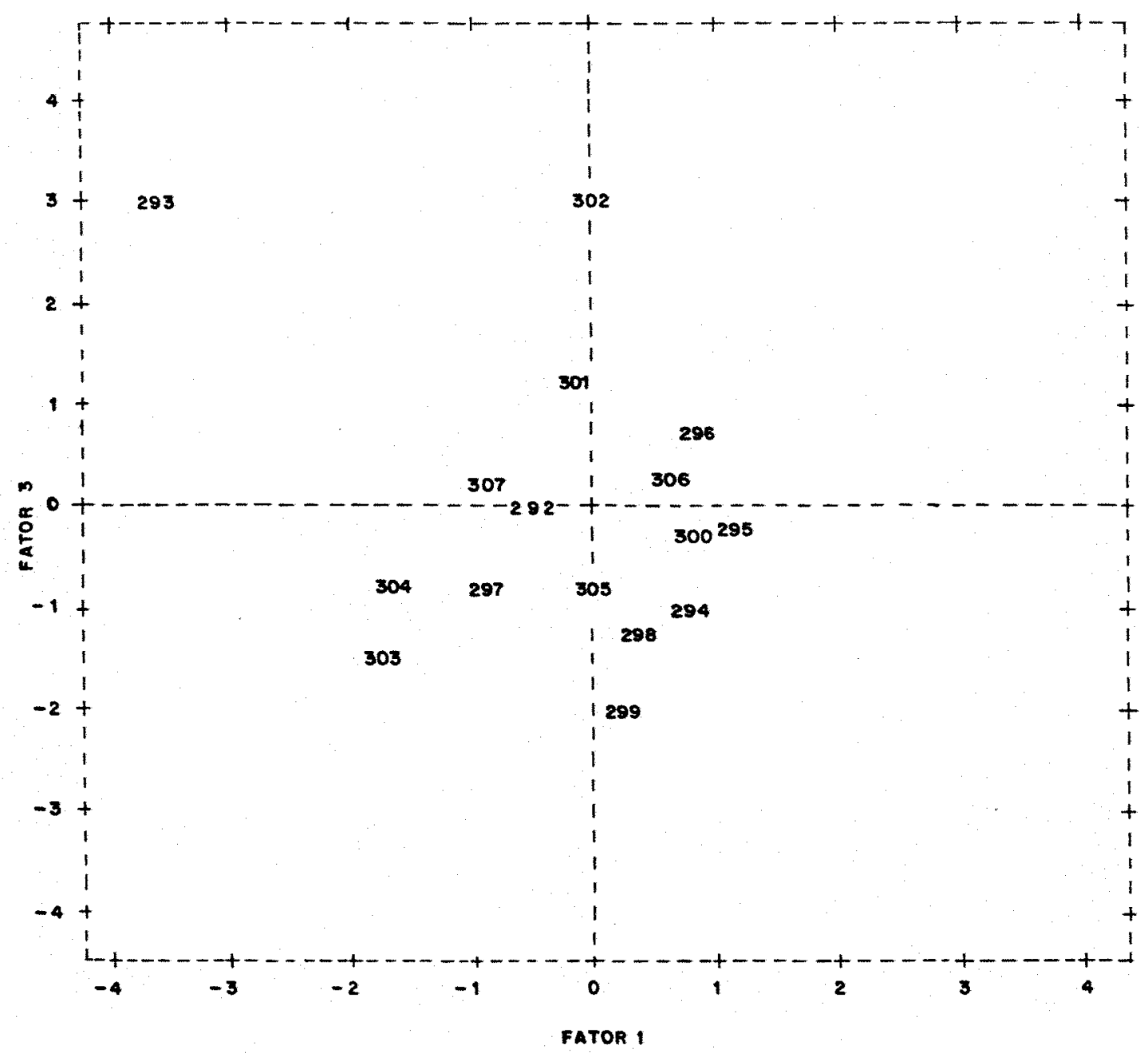

Figura 4. Representagáo graficadacombinacádos valores dos fatores F1 - Propriedade Familiar e F3 - Uso Intensivo de Hecanizasa e Insumos Modernos, segundo as microrregioes homogeneas de Santa Catarina, em 1980. 


\subsubsection{Regioes diferenciadas quanto ao grau de modernizacáo}

Combinando os resultados da analise fatorial e as caracterlsticas da agropecuaria, estabeleceram-se sete regioes diferenciadas quanto ao grau de modernizagáo na agropecuaria em 1980. Na figura 5 encontram-se as regiós de acordo com o grau de modernizacá, cujo detalhamento ef feito a seguir.

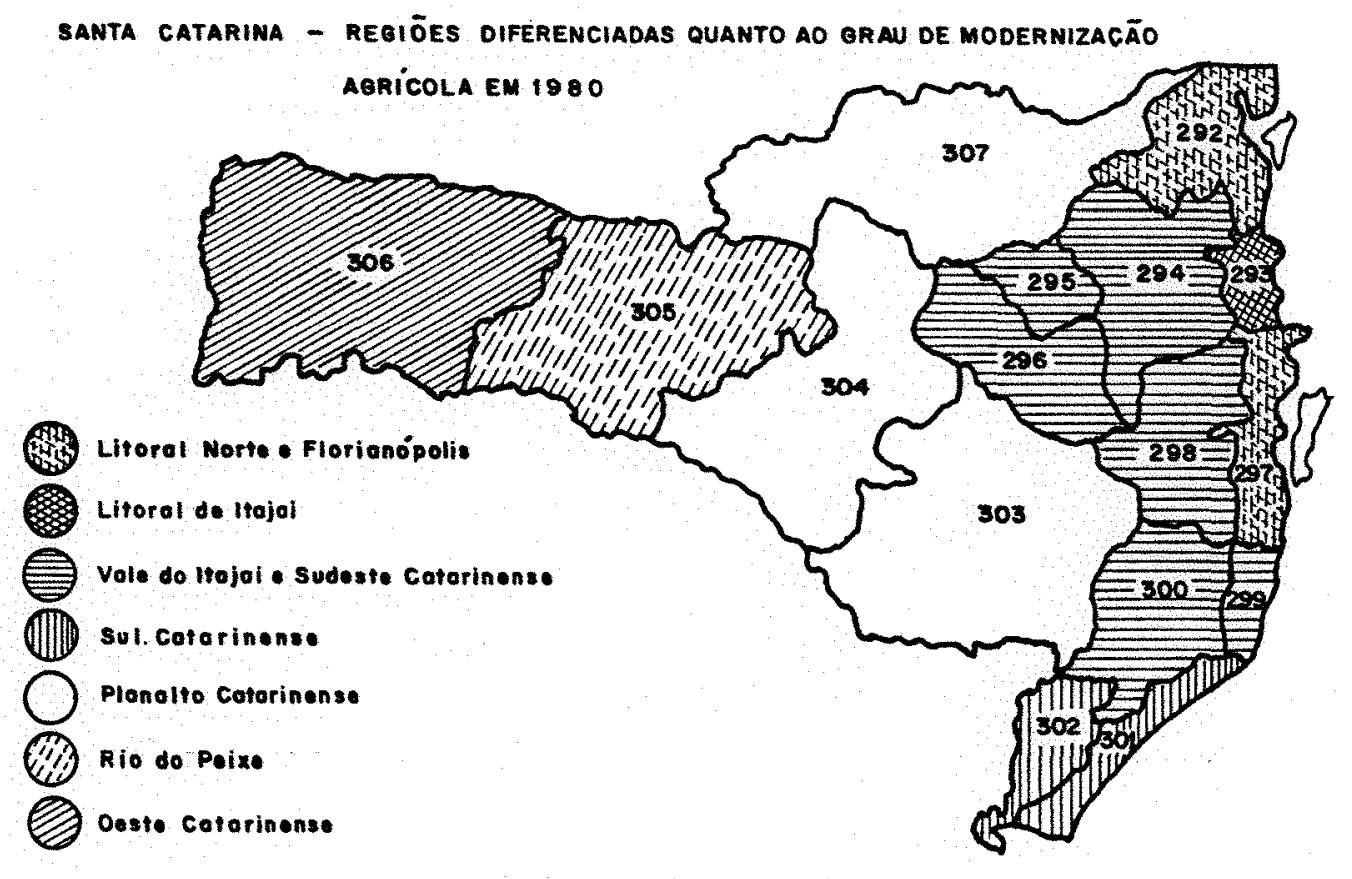

Figura 5. Regioes diferenciadas quanto ao grau de modernizaca em Santa Catarina, en 1980. 
Regiáo 1. Litoral Norte e Floriandpolis. Agrega as microrregiofs homogeneas 292-Colonial de Joinville e 297-Florianopolis, que apresentam valores negatjus para F1, e valores positivos para F2. Esta regia pode ser caracterizada pela criaga modernizada e pela absorgo de financiamentos. Nestas microrregioes homogeneas, a produca de origen animal contribui com parcela significativa do valor da produca agropecuaria, con destaque para a avicultura. Embora a producao avlcola seja importante a nlvel de microrregia homogenea, e pouco expressiva no plano estadual.

A microrregizo homogenea 292-Colonial de Joinville tem sua populacto predominantemente urbana e sua economia esta baseada no setor industrial. Conforme MATTOS (1986), cerca de $25 \%$ do Produto industrial catarinense tem origem nesta microrregia homogenea. En fungalo do tipo de estrutura industrial instalada na regigo - caracterizada como capital intensiva - a agropecuaria tende a assumir uma importancia relativa menor. Por sua vez, a microrregia homogenea 297-Florianopolis, for ser o centro politico e administrativo do Estado, tambem apresenta fouco destaque na agropecuaria, considerando o contexto socio-economico regional.

Regiăo 2. Litoral de Itaja1. Sem dtuida, a microrregiáo homogenea 293-litoral de Itajal ocupa uma posicao destacada quanto a modernizaca agricola. Apresenta valores elevados e positivos para F2 eF3, com caracteristicas de uma agropecuaria onde ha uso intensivo de mecanizacao e insumos modernos, e absorvedora de capital financeiro. 
Embora a microrregiáo homogenea 293-Litoral de Itajal contribua com apenas $0,8 \%$ do valor da produfáo agropecudria catarinense em 1980, os resultados obtidos situan-na como sendo uma area agricola das mais modernizadas no Estado. Esta constatagäo poderia ser um equivoco, pois a regia e conhecida pelo turismo e pela produca pesqueira. No entanto, esta posicto destacada quanto a modernizacto édevida a presenca de lavouras de cana-de-actcar, conduzidas com elevado padrao tecnologico. O sistema de produca adotado para estas lavouras nao reflete a agricultura da regia como un todo, pela concentracáo da atividade em torno de uma tuica empresa.

No municlpio de Ilhota esta situada a usina de cana-de-actcar do Grupo Usati, que tem producao propria da maior parte da materia-prima processada. O municipio concentra cerca de $70 \%$ da produca de cana-de-actoar e 60\% dos financiamentos obtidos na microrregizo homogenea, en 1980. Esta producao concentrada para atender a demanda industrial localizada em Ihota utiliza tecrologia elevada para os padroes estaduas, mecanizacago trabalho assalariado. Trata-se, portanto, de uma agricultura onde predominam relacbes capitalistas de producáo.

Regiao 3.Vale do Itajal e Sudeste Catarinense. A regiao formada pelas microrregioes homogeneas 294-Colonial de Elumenau, 295Colonial de ltajal do Norte, 298-Colonial Serrana Catarinense, 299-Litoral de Laguna e 300-Carbonifera, que apresentam valores positivos parafl e negativos para F2 e F3; e pela microrregiao homogenea 296-Colonial do Alto Itajal, com valor positivo para F1 
e F3, e negativo para F2. Com excepắ da microrregiăo homogenea 296-Colonial do Alto Itajal, as demais microrregibes homogeneas aparecem no quarto quadrante dos graficos das Figuras 3 e 4. Entre as atividades relevantes da Regiáo 3 , encontra-se o fumo e a cebola, que sao exploragos tipicas de pequenas propriedades, com absoreato de máde-obra familiar. o vale do Itajal abriga tambem uma bacia leiteira importante.

Regico 4. Sul Catarinense. Com valores positivos e elevados para F3, e regativos para F2, esta regia destaca-se pelo emprego de tecnicas modernas, especialmente mecanizaca com uso de tratores de maior potenciale insumos agroquimicos. As microrregibes homogeneas 301-Litoral sul catarinense e 302-Colonial Sul Catarinense fazem parte desta regiao e tem o arrozirrigado e o fumo como atividades relevantes. A microrregia homogenea 302Colonial sul Catarinense possui uma area apta a agricultura maior do que a microrregiă homogenea 301-Litoral Sul Catarinense e utiliza as tecnicas modernas de producáo com maior intensidade.

Regiá 5. Planalto Catarinense. Agrega as microrregioes homogeneas 303-Campos de Lages, 304-Campos de Curitibanos e 307Planalto de Canoinhas, com valores quase sempre negativos para os tres fatores, refletindo uma agropecudria náo modernizada. Entre as atividades de importancia nesta regiá, encontra-se a pecuaria extensiva e a silvicultura. No entanto, restas microrregioes homogeneas existe uma agricultura tipicamente capitalista, com alta tecnologia e absorsolo de trabalho assalariado (lavouras de alho, batata-semente e mata). Porem este tipo de atividade ná e captado felos indicadores utilizados, por 
ocupar uma area proporcionalmente pequena em relagáo ás atividades predominantes (pecudria e extrabo vegetal), que definem as caracteristicas regionais.

Regiáo 6. Vale do Rio do Peixe. Representada pela microrregiao homogenea 305-Colonial do Rio do feixe, destaca-se pelo elevado grau de modernizacto de sua agropecuaria. Caracteriza-se pela criafa modernizada e absorga de capital financeiro. Ocupa uma posifá de neutralidade en relaga a Fl, ou seja, os valores para este fator equivalem aos valores medios do Estado. A avicultura e a suinocultura sŏo as principais atividades agropecuarias, conduzidas em pequenas fropriedades familiares, integradas ao complexo agroindustrial. E o elevado padra tecnoldgico empregado na criafáo de aves e suinos que contribui para que esta regiáo se destaque quanto ao grau de modernizagáo. Cerca de um teroo do valor da producto agropecuaria regional en 1980 e obtido em Concordia, que concentra tamben a producáo de aves e suinos. Outra atividade de grande importancia regional a produca de mafa, concentrada no municipio de Fraiburgo.

Regiao 7. Oeste Catarinense. Formada pela microrregia homogenea 306-Colonial do Oeste catarinense, a tuica a apresentar valores positivos, embora na muito elevados, para F1, F2 e F3. Fosiciona-se sempre no primeiro quadrante, refletindo uma agropecuaria relativamente modernizada. Os valores mais elevados Para F1 e F2 estao coerentes com a realidade regional: a microrregio homogenea 306-Colonial do Oeste Catarinense tem sua agropecuaria assentada na pequena propriedade familiar, e a 
criaga de pequeno porte e atividade relevante na regiáo. No periodo em andise, a suinocultura tinha uma importancia maior do que a avicultura, cujo desenvolvimento foi ampliado posteriomente a 1980. A menor participaca da avicultura no contexto regional, em 1980, pode justificar, em parte, o indice tecnologico inferior, comparativamente a microrregiálo homogenea 305-Colonial do Rio do Feixe. As linitacos quanto a mecanizaglo influenciam os valores de F3, que se apresentan menos elevados para esta regiăo. Na principal regiăo agricola do Estado, năo se verifica concentrafáo da produca nos municlpios.

As microrregibes homogeneas 305-Colonial do Rio do Peixe e 306-Colonial do oeste Catarinense sao responsaveis por mais de $50 \%$ do valor da produoto agropecuaria obtida em Santa Catarina, en 1980. Nestas regioes ha uma realidade que nálo pode passar despercebida quando se analisa a modernizafa na agropecuaria: a integracto dos pequenos agricultores ao complexo agroindustrial, notadamente na avicultura e na suinocultura.

Conforme SoRJ et alíi (1982), a avicultura modernizada tem sido apontada como um dos mais expressivos exemplos do desenvolvimento do capitalismo na producáo animal. $\boldsymbol{L}$ na avicultura industrial que vamos encontrar umalto nivel de controle das condigoes naturais de producá, o que possibilita um alto grau de conversalo alimentar em carne de frango, a prazos e a custos menores que o conseguido com outras criagies. Ilesde o melhoramento genetico animal, a producáo de rafibs e medicamentos, ate a comercializaquo do produto final, e uma atividade altamente articulada com o complexo agroindustrial. 
A avicultura modernizada em Santa Catarina ganhou espafo a partir da implantacao dos sistemas integrados de produca. Nestes sistemas, predominantes no oeste e no sul catarinense, a indtstria integradora fornece os insumos e fatores necessarios a produga, enquanto o agricultor ten assegurada a aquisifá da produgao. O modelo tecnologico implementado pelas empresas integradoras garantiu aos avicultores catarinenses conquistar a hegemonia na producato nacional de carne de aves. 0s Indices de produtividade aqui alcangados se assemelham aos obtidos nos paises mais desenvolvidos. As empresas integradoras em geral sao constituldas por grandes conglomerados e atuan com uma organizacao voltada a modernizacolo. CEPA/SC, 1988b. PP $255-66)$.

A modernizaca na avicultura foi influenciada Frincipalmente por ter sido uma atividade exogena, implantada segundo un modelo de integrapáo importado dos palses desenvolvidos. A atividade, nos moldes como exercida nos dias atuais, năo existia anteriormente. Por outro lado, havia o mercado externo favoravel, ben como os benefloios concedidos as exportafoes de produtos industrializados.

Na suinocultura, entretanto, a modernizacolo foi mais lenta, possivelmente por ser uma atividade tradicionalmente desenvolvida na regia. Este fato pode ter dificultado o processo de adofáo de inovacos tecnologicas. A producáo de carne sulna, por sua vez, enfrenta restrigoes a exportacao, tendo em vista que os grandes consumidores sto tambem grandes produtores. 
Outra caracteristica da modernizacalo na agropecuaria catarinense refere-se a pouca alterafáo sofrida nas relafies sociais de produgắo. Apesar do desenvolvimento capitalista, o trabalho familiar e a unidade de produgádamiliar náo desaparecem. 0 assalariamento agricola ocorre em nivel bastante inferior ao de outras regiós. Esta situacto pode ser favorecida pelo tipo de contrato estabelecido entre o produtor e a empresa integradora. De acordo com EELATO (1985), o contrato estabelecido entre o produtor e a empresa ná implica em simples venda da forfa de trabalho do agricultor. Na realidade, a pequena propriedade vai se adaptar aos interesses da agroindtstria atraves da realizacáo de investimentos de capital. E fundamental tambem que o agricultor seja pequeno proprietario. Ser proprietario de terra significa ter credito bancario para investimentos de capital, mediante a hipoteca da terra.

Chega a ser lugar-comum associar a pequena propriedade familiar a ariculturatradicional, marginalizada da modernizaga tecnologica, e con fouco acesso ao credito rural. 0 que se constata, com os resultados aqui apresentados, e que nao ha contradica entre propriedade familiar e modernizaca nas Principais regioes jyricolas catarinenses. 


\subsection{Analise das Relaqós entre Hodernizagáo na Agropecuaria e as Distribuifós de Renda e da Posse da Terra}

Esta etapa consiste no teste das hipoteses formuladas na introdugăo, e constitui a fase explicativa da pesquisa. As relapoes entre modernizaco na agropecuaria e distribuifáo de renda, distribuifao da posse da terra e pobreza, foram analisadas atraves de regressos lineares moltiplas, ajustadas pelo metodo dos minimos quadrados fonderados. o fator de ponderafo foi o mesmo utilizado na analise fatorial, ou seja, o numero de pessoas de familias cujo chefe tem atividade principal na agropecuaria. As unidades de analise sao as 16 microrregioes homogeneas de Santa Catarina.

Dcorrendo heterocedasticia, os quadrados dos desvios deven ser ponderados, e fator de ponderacalo deve ser inversamente proporcional a variancia, ou seja, deve ser dado peso maior as observaófes de menor variancia. Ha evidencia de heterocedasticia pois apenas a microrregia homogenea 306Colonial do oeste catarinense detem cerca de $32 \%$ do numero de pessoas da distribuiga escolhida.

As variaveis relacionadas com distribuifa de renda e pobreza foram extraldas de HOFFMANN (1987) e estao no Capltulo 3. As variaveis referentes a modernizaca na agropecuaria sto os valores dos fatores r resultados da analise fatorial, tabela 11). As variaveis e seus respectivos simbolos estao relacionados a seguir. For simplicidade, o mesmo slmbolo usado tanto para indicar valores observados como valores 
estimados da variavel.

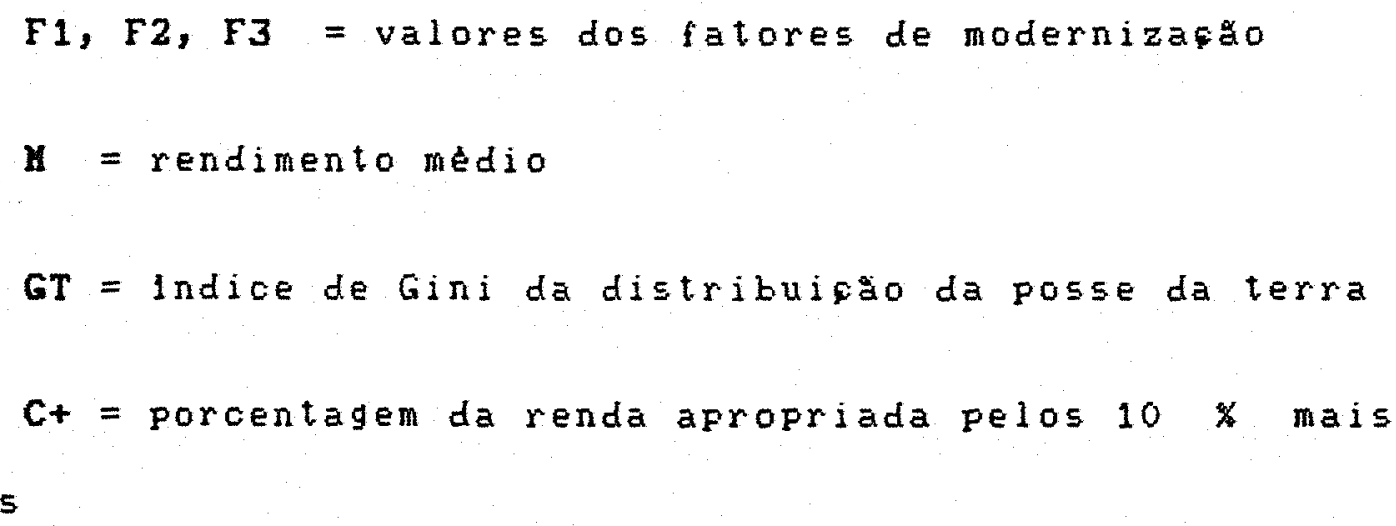

$\operatorname{ricos}$

$G=$ Indice de Gini da distribuifo de renda

$H=$ proporga de pobres, com linha de pobreza igual a 0,25 de salario minimo "per capita"

P = Indice de pobreza de sen 


\subsection{Resultados da Andise de Regressto}

Na tabela 12 estăo os resultados das regressoes lineares entre as caracteristicas da distribuifáo de renda, fatores de modernizaça e posse da terra. Junto com os resultados, abaixo da estimativa do parametro, entre parenteses, e apresentado o valor do correspondente teste "t ". Este valor e assinalado com um asterisco quando for significativo para um teste bilateral da hipotese de nulidade do parametro, ao nlvel de significancia de $5 \%$. O ntmero de observactes e igual ao ntmero de microrregioes homogeneas $(n=16)$.

A variavel dependente é sempre uma caracterlstica da distribuica de renda crenda media, desigualdade ou medida de pobreza). As variaveis independentes sao os valores dos tres fatores de modernizacto (F1, F2, F3) e o lndice de Gini da desigualdade de distribuifo da posse da terra.

Os resultados obtidos nao revelam, de maneira clara, a relaoğo entre distribuifáo de renda, modernizacáo na agropecuaria e desigualdade de distribuigáda posse da terra. Os valores para os correspondentes testes "t "nă rejeitam a hipotese de nulidade dos parametros. Alem disso, o coeficiente de determinacá (R2) e baixo para todas as equacos, mostrando que as variaveis testadas sao pouco explicativas.

Embora nas equacies tendo renda media como variavel dependente o coeficiente de determinaso tambem seja baixo, a renda media se mostrou associada, com significancia estatistica, ao tipo de modernizaca caracterizada por F2. 
Espera-se que nas regioes com valores positivos e elevados para F2, a modernizaco seja acompanhada de elevacao na renda media.

Ao interpretar os resultados das regressos a importante lembrar certas limitafies dos dados sobre distribuifao de renda. Os rendimentos medios estáo subestimados pelo fato de nago incluirem o valor da produắo para autoconsumo, que e um componente substancial da renda no caso da produca familiar. Como Fl esta associado com a propriedade familiar, o efeito negativo (e náso sgnificativo) de F1 sobre m talvez seja devido a maior subsetimagăo do rendimento medio na producto familiar.

A inclusao de uma variavel explicativa, relacionada com posse da terra, contribuiu para aumentar o coeficiente de determinacáo do modelo que analisa as relafos entre renda agricola e modernizacáo. Entretanto, apesar de aumentar o poder de explicagáo do modelo, "enfraquece" a variavel F2, que passa a ser significativa apenas a $10 \%$.

As relacoes entre pobreza e modernizafa da agropecuaria tambem na ficam evidenoiadas. Novamente, o coeficiente de determinaca indica que as variaveis explicam pouco a variagáo na pobreza.

a sinal associado a cada parametro estimado fornece um indicativo do comportamento dos fatores de modernizaca em relaga as medidas de renda. Nas equactes tendo G , Ct e $\mathbf{X}$ como variavel dependente, observa-se que F1 e F 3 tem sinal negativo, e F2 e GT tem sinal positivo. Nas equacoes tendo H e P como variável dependente, o sinal e negativo para F2, e 
TABELA 12 - Resultados das regressöes lineares mültiplas entre indicadores de renda, modernizaçào da agropecuäria e posse da terra, para as 16 microrregiōes homogēneas de Santa Catarina, em 1980.

\begin{tabular}{|c|c|c|c|c|c|c|c|}
\hline \multirow{2}{*}{$\begin{array}{l}\text { VARIAVEL } \\
\text { DEPENDENTE }\end{array}$} & \multirow{2}{*}{$\begin{array}{c}\text { TERMO } \\
\text { CONSTANTE }\end{array}$} & \multicolumn{4}{|c|}{ COEFICIENTES DE REGRESSAO } & \multirow{2}{*}{$\mathbf{R}^{2}$} & \multirow{2}{*}{$\begin{array}{c}\text { TESTE } \\
\mathbf{F}\end{array}$} \\
\hline & & $F_{1}$ & $F_{2}$ & $F_{3}$ & $\overline{G T}$ & & \\
\hline \multirow[t]{2}{*}{$\mathbf{G}$} & 0,392 & $-0,012$ & 0,016 & $-0,003$ & 0,157 & 0,306 & 1,21 \\
\hline & $(1,646)$ & $(-0,469)$ & $(1,243)$ & $(-0,214)$ & $(0,404)$ & & \\
\hline \multirow[t]{2}{*}{$c^{+}$} & 29,4 . & $-1,886$ & 1,159 & $-0,596$ & 14,7 & 0,357 & 1,53 \\
\hline & $(1,224)$ & $(-0,724)$ & $(0,885)$ & $(-0,338)$ & $(0,374)$ & & . \\
\hline \multirow[t]{2}{*}{$\mathbf{M}$} & 0,632 & $-0,016$ & 0,059 & $-0,010$ & - & 0,332 & 1,99 \\
\hline & $(25,385 *)$ & $(-0,654)$ & $(2,323 *)$ & $(-0,400)$ & - & & \\
\hline \multirow[t]{2}{*}{$\mathbf{M}$} & 1,164 & $-0,067$ & 0,052 & $-0,037$ & $-0,873$ & 0,399 & 1,82 \\
\hline & $(2,416 *)$ & $(-1,288)$ & $(2,012)$ & $(-1,057)$ & $(-1,106)$ & & \\
\hline \multirow[t]{2}{*}{$\mathbf{B}$} & $-0,146$ & 0,026 & $-0,015$ & 0,012 & 0,724 & 0,246 & 0,89 \\
\hline & $(-0,399)$ & $(0,665)$ & $(-0,801)$ & $(0,467)$ & $(1,205)$ & & \\
\hline \multirow[t]{2}{*}{$\mathbf{P}$} & $-0,107$ & 0,018 & $-0,003$ & 0,008 & 0,413 & 0,160 & 0,52 \\
\hline & $(-0,491)$ & $(0,770)$ & $(-0,329)$ & $(0,541)$ & $(1,157)$ & & \\
\hline
\end{tabular}


positivo para os denais coeficientes de regressa. 0 sinal positivo para a variavel relacionada com estrutura fundidria indica que a desigualdade de distribuicáco de renda cresce onde a desigualdade de distribuiga da posse da terra e maior. Esta relaga fica pouco evidente para Santa Catarina.

Foram testados modelos noo lineares para as relacbes entre modernizaga da agropecudria e indicadores de renda e da posseda terra. O modelo aplicado contou com uma medida de desigualdade de distribuifoo de renda como variavel dependente: de forma alternativa testou-se o Indice de Gini da distribuifá de renda (G) e a proporcáo apropriada pelos $10 \%$ mais ricos $(C+)$. Como varidveis independentes considerou-se rendimento medio, termo quadratico para rendimento medio, fatores de modernizagáo e indice de Gini da desigualdade da posse da terra. Com os resultados obtidos, apresentados a seguir, náo se confirma a relacao parabolica entre desigualdade e renda agricola. Mas equaqoes nao-lineares os sinais entre as variaveis selecionadas sao semelhantes aos obtidos nas equacoes lineares.

\section{Equafao (1)}

$$
\begin{aligned}
G= & 0,032+1,073 M-0,787 M^{2}-0,012 F_{1}+0,014 F_{2}-0,007 F_{3}+0,167 \mathrm{GT} \\
& (0,051)(0,600) \quad(-0,581) \quad(-0,397) \quad(0,873) \quad(-0,362) \quad(-0,374) \\
& \text { com } R^{2}=0,335 \text { e teste } F=0,756
\end{aligned}
$$


Equąăo(2)

$$
\begin{aligned}
& \mathrm{C}^{+}=-8,64+117,9 \mathrm{M}-87,8 \mathrm{M}^{2}-1,998 \mathrm{~F}_{1}+1,054 \mathrm{~F}_{2}-1,138 \mathrm{~F}_{3}+14,2 \mathrm{GT} \\
& (-0,136)(0,655)(-0,644)(-0,655) \quad(0,637) \quad(-0,512) \quad(0,316) \\
& \text { com } \mathrm{R}^{2}=0,387 \text { e teste } \mathrm{F}=0,948
\end{aligned}
$$

Tratando-se das relagoes entre pobreza e renda agricola, adotou-se uma medida de pobreza(P ou $H$ ), testada alternativamente como variavel dependente. As variaveis independentes foram rendimento medio, termo quadratico para rendimento medio, e Indice de Gini da distribuicao de renda. o resultado mais significativo foi obtido utilizando proporfáde pobres como variavel dependente. As equacoses ajustadas foram:

Equafo (3)

$$
\begin{aligned}
& \mathrm{H}=0,511-1,710 \mathrm{M}+0,831 \mathrm{M}^{2}+1,069 \mathrm{G} \\
& (8,071 *)(-8,975 *)(5,814 *)(30,363 *) \\
& \text { com } \mathrm{R}^{2}=0,993 \text { e teste } \mathrm{F}=625,396 *
\end{aligned}
$$

Equafăo (4)

$$
\begin{aligned}
& \mathrm{P}=0,189-0,776 \mathrm{M}+0,337 \mathrm{M}^{2}+0,630 \mathrm{G} \\
& (2,502 *)(-3,417 *)(1,977) \quad(15,003 *) \\
& \operatorname{com} \mathrm{R}^{2}=0,971 \text { e teste } \mathrm{F}=136,742 *
\end{aligned}
$$


Na relafá parabolica entre $H$ e $H, ~ o$ ponto de minimo e 1,029. Todas as microrregioes homogeneas de Santa Catarina situam-se abaixo deste valor. Assim, um aumento de renda media e acompanhado de uma diminuigá da pobreza absoluta, caso nao ocorra um aumento da desigualdade. Um aumento de desigualdade, sem alteraco da renda media, leva a um aumento da pobreza. A relaga esperada entre as variaveis é confirmada na equafá (3), com significancia estatistica para o termo quadratico. Na equaca (4), a relaca parabolica năo e significativa.

o aumento da desigualdade da distribuifóde renda na agropecuaria brasileira na decada de 70 esta associada com o processo de modernizagáo agricola, conforme comprovam pesquisas desenvolvidas por HOFFMANN $\underline{t} \underline{\underline{t}} \underline{\underline{i}} \underline{i}$ (1985), HOFFHANN \& KAGEYAMA, (1985), TRONCOSO LEONE (1988), HOFFMANN \& KASSOUF (1989), DEL GROSSI (1989), e KIYUMA(1989). Porem o aumento na desigualdade distributiva, paralelamente modernizaca na deve ser entedida como uma condica necessaria do processo de transformacao tecnologica a que esteve submetida a sociedade brasileira nos ditimos anos. Alem das razóes historicas de desigualdade de distribuica da posse da terra no Erasil, que influencia a desigualdade de distribuiga de renda, a polltica agricola adotada nas titimas decadas tem se caracterizado por ser concentradora de renda e distribuidora de privilegios a uma minoria. 
Este estudo na comprovou para as microrregioes de Santa Catarina, as evidencias obtidas nas pesquisas oitadas anteriormente. Cabe destacar alguns fatores que poden influenciar os resultados obtidos: embora as microrresioes homogeneas de Santa Catarina apresenten indices de desigualdade de distribuiga da renda relativamente menores, quardo comparados com a Regia Sul e o Erasil, as diferengas entre as medidas de distribuifa de renda nas microrregios homogeneas nao sa muito expressivas, havendo uma relativa homogeneidade dos dados; o ndmero de observactes e reduzido $(n=16)$. A iniluencia destes fatores certamente seria menor, caso o estudo fosse desenvolvido tendo os municlpios como unidades de observaco.

E oportuno lembrar tamben a presenfa de oligopolios e a influenoia da proximidade do setor industrial, nas condifoses especificas de Santa catarina. Quando a renda gerada na agropecuaria valorizada e seu excedente parcialmente apropriado pelas pessoas do setor industrial e/ou comercial, os dados referentes a pessoas ocupadas na agropecuaria subestiman a renda gerada no setor e na permitem captar toda a desigualdade de distribuifato dessa renda. 


\section{CONCLUSOES}

As estrategias de desenvolvimento agricola adotadas no Erasil, durante a decada de 70 , basearam-se na modernizaglo do setor e possibilitaram o aprofundamento das relacoes intersetoriais. O modelo adotado, entretanto, repercutiu ampliando as desigualdades sociais. Ha evidencias de que a politica agricola favoreceu uma minoria, consolidando privilegios numa sociedade que, historicamente, caracteriza-se pela desigualdade distributiva. Diversos estudos ja realizados confirman a associaga direta entre a modernizagáo agricola e o aumento da desigualdade de distribuigăo de renda, nas condifoes socio-economicas do Brasil.

Devido ao processo historico de ocupacáo da terra, as diferencas sociais na agropecuaria catarinense sao menos pronunciadas que em outras regioes brasileiras. A estrutura agraria catarinense, embora tenha sofrido alteracoses na decada de 70, mantem sua principal caracteristica: a pequena propriedade familiar. Deve-se destacar tambem a diversificagáo economica em Santa catarina, onde a industrializagáo descentralizada contribui para elevar a renda media da populagáo rural, e conferir melhores condigoes de vida, notadamente no vale do Itajal. Com as peculiaridades do quadro agrario catarinense como 
cenario, o estudo foi desenvolvido tendo como objetivo central evidenciar as relacbes entre a modernizaca e o aumento no grau de desigualdade de distribuica de renda na agropecuaria.

A imagen associando a pequena propriedade familiar a agricultura tradicional, a margen da modernizacto e do acesso ao credito rural, perde sentido nas principais regibes agricolas catarinenses. Os fatores de modernizagáo indicam que năo há contradifá entre propriedade familiar e modernizacalo na agropecuaria.

Por outrolado, pode-se afirmar que a estrutura produtiva catarinense modernizou-se atraves de atividades tipicas de pequenas propriedades familiares, como avicultura, suinocultura e produca de fumo. Estas atividades, altamente articuladas ao Complexo Agro-lndustrial, mostraram-se viabilizadoras da modernizaóo, mantendo a estrutura agraria. Houve uma adequaclo da pequena propriedade familiar como absorvedora de insumos industriais e como fornecedora de materiaprima a agroindustria.

Analisando as posicoes ocupadas pelas microrregibes atraves da combinafa dos valores dos fatores, e possivel perceber que a modernizagáo náo ocorreu de forma homogenea nas diversas regioes do Estado. Os resultados obtidos permitem evidenciar 7 regibes diferenciadas quanto ao grau de modernizaflo. confirma-se aqui o pressuposto de que a modernizago atua no sentido de ampliar as desigualdades regionais. Assim, a regionalizaga da agropecudria pode 
constituir un instrumental util na elaborafáde politicas para o setor, evitando-se tratar de maneira semelhante aquilo que e desigual. Neste sentido, o presente estudo pode contribuir com informases sistematizadas para o flanejamento de estrategias governamentais, apropriadas as caracterlsticas de Santa catarina e as suas microrregibes homogeneas.

Quanto as relacoes entre modernizaca e distribuifa de renda, os resultados obtidos com a analise de regressá na confirmam as evidencias emplricas comprovadas por HOFFHANN Et ali i (1985); HOFFHANK \& KAGEYAMA (1986); TRONCOSO LEONE (1988); HOFFHANN A KASSOUF (1989); UEL GROSSI (1989) e KIYUNA (1989). Alem do coeficiente de determinagáo baixo, náo se rejeitou a hipotese de nulidade dos parametros estimados. Em outras palavras, utilizando as microrregióes homogeneas de santa Catarina como unidades de observaqá, náo săo estatisticamente comprovados os efeitos da modernizagáo da desigualdade da distribuifá da posse da terra sobre as caracteristicas da distribuifăo da renda.

Observou-se que Santa Catarina apresenta um grau relativamente baixo de desigualdade de distribuigáo da renda. Ha uma relativa homogeneidade dos dados e o numero de observafós é pequeno. Uma vez que os resultados da analise de regressao sao influenciados fela pouca variagá nas medidas de desigualdade e Felo ntmero reduzido de observagos, sugere-se que estudos semelhantes sejam desenvolvidos tendo os municipios catarinenses como unidades de andise. 


\section{REFERENCIAS BIBLIOGRAFICAS}

EAY-PETERSEN, J. New technology for low-income farmers in

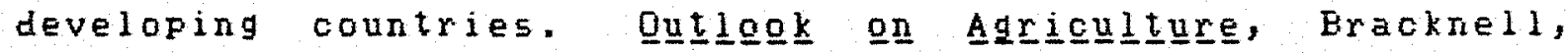
Eerks., 15(3): $110-4,1986$.

BELATO, I. Us camponeses integrados. Campinas, 1985. $2 \mathrm{v}$. (Mestrado - Universidade Estadual de Campinas).

CEFA/SC.Comissa Estadual de Flanejamento Agricola. Estudog

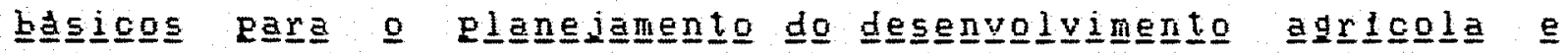
rua․ Parte I. Florianofolis, 1978.

CEPA/SC. Instituto de Flanejamento e Economia Agricola de Santa

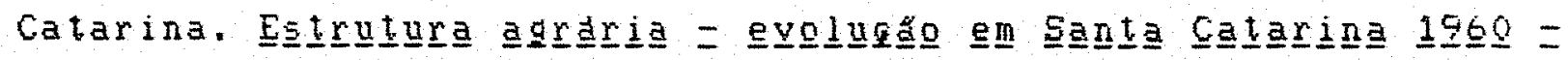
1990. Florianbpolis, 1984.75p.

CEPA/SC. Instituto de Plarejamento e Economia Agricola de Santa

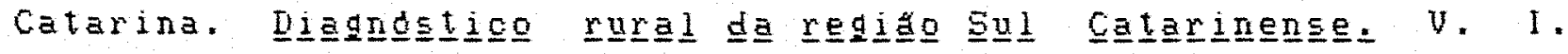
Florianopolis, $1988 \mathrm{a} . \quad 241 \mathrm{~F}$.

CEFA/SC. Instituto de Flanejamento e Econonia Agricola de Santa

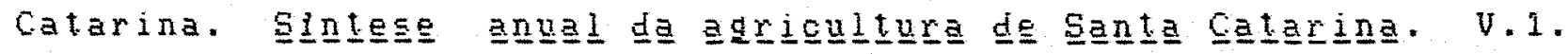


Floriandpolis, $1980 \mathrm{~b} .40 \bar{p}$.

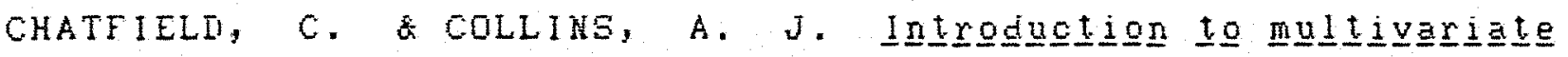
anglysis. Londres e Nova York, Chafman e Hall, 1980. $246 \mathrm{f}$.

CIINE, W.R. Iistribution and development:a survey of literature.

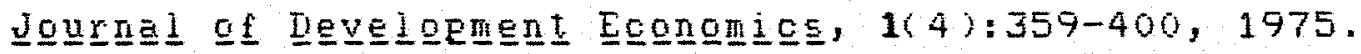

DELGADo, G.C. Cafital financeiro e agrioultura no desenvolvimento recente da economia brasileira. Campinas, 1984. (Doutorado Universidade Estadual de Campinas).

IEL GROSSI, M. E. Dietribuiqá de renda na agropecudria paranaense. Piracicaba, 1989. 129f. (Mestrado - Escola Superior de Agricultura "Luiz de Queiroz"/ USF)

IENSOW, JR \& TYLER,W.G. Persfectivas sobre pobreza e desigualdade de renda no Erasil. Fesguisa e Flanejamento Egongmicog, Rio de Janeiro, $13(3): 863-904,1983$.

FIELDS,G.S. Poverty ineguality and develogment. New York, Cambridge U.P. 1980.

FRANCO, H.M. Leite em Santa Catarina: realidade sugere

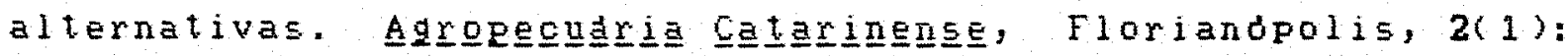
$26-36, \operatorname{mar} \cdot 1989$.

FUENTES LLANILLO, R. Caraoterizago da estrutura da producto agropecuaria no Estado do Parane. Piracicaba, 1984. 177p. CMestrado - Escola Superior de Agricultura "Luiz de Queiroz"/USP? 


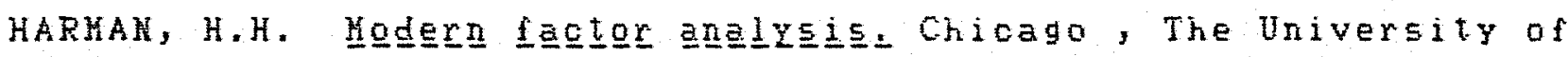
Chicago Frese, $1970.487 \mathrm{p}$.

HEEIT, R.V. A retrospective view of technological and other changes in philippine rice farming, 1965-1982, Egongmig Ieqe

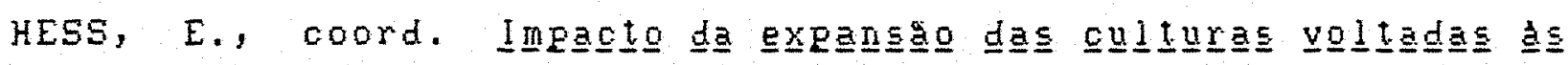

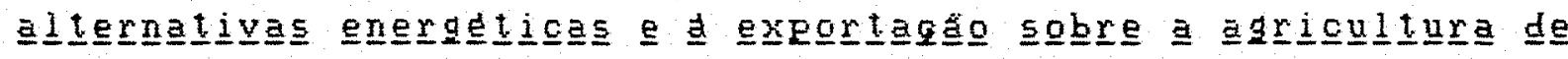
Ilimentgs. Curitiba, IFARDES - Fundacao Edison Vieira, 1983. $2 \mathrm{v}$.

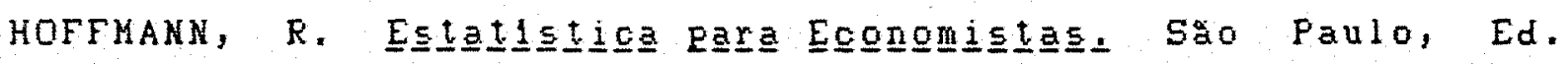
Fioneira, 1980. $379 \mathrm{~F}$.

MOFFMAN, R. Evolucto da desigualdade da distribuifao da posse da terra no Erasil no periodo 1960 - 80 . Reforma Agrấa Campinas, 12(6):17-35, nov.-dez. 1962.

HOFFMAN, R. A Fobreza no Brasil: analise dos dados dos censos Demograficos de 1970 e 1980. In ENCONTRO ERASILEIRO DE ECONOMETRIA, 11., S9O Paulo, 1984.

HOFFMAN, R. Distribuiga de renda e pobrezana agrioultura brasileira. Piracicaba, FEALQ, 1987. 151f. (Relatorio de Pesquisa)

HOFFMAN, R. U Indice de desigualdade de Theil - Atkinson. In: ENCONTRO ERASILEIRO DE ECONOMETRIA, 11., Fortaleza, 1989. 


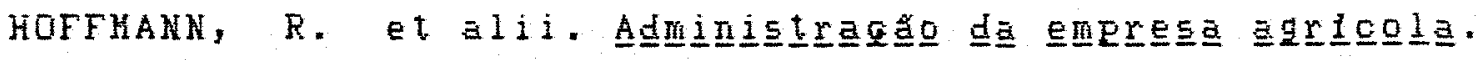
2 Ed. Sao Faulo, Fioneira, 1978. 325p.

HOFFMAN, F, et alii. Ingyagoes tegnglogigas trangformageg

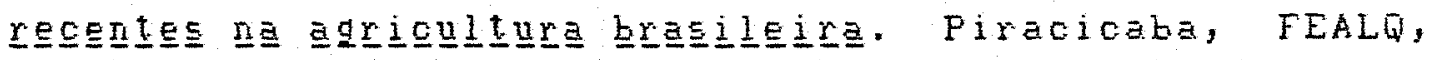
1985. 4 v. (Relaterio de Pesquisa)

HOFFMANN, R. KAGEYAMA, A.A. Distribuigeo de renda no Erasil entre familias e entre pessoas em 1970 e 1980.

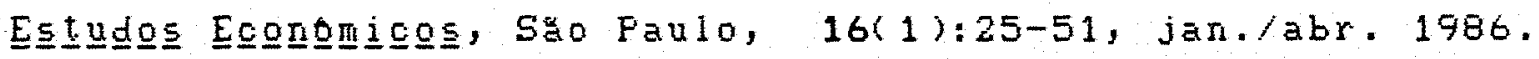

HOFFMAN, R. \& KASSOUF, A. L. Modernizagá e desigualdade na

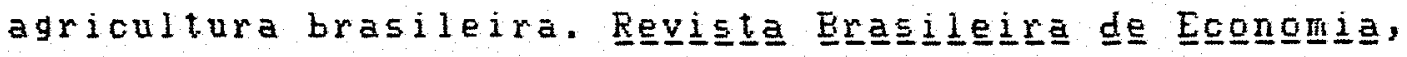
Rio de Janeira, 43(2): $273-303$, abr./jun. 1989.

IBGE. Censo Agropecuario 1970, Santa Catarina, Volume II, Tomo XX. Rio de Janeiro, 1975.

IBGE. Censo Agropecuario 1975, Santa Catarina, Volume 1 Tomo XIX. Rio de Janeiro, 1979.

IBGE. Censo Agropecuario 1980, Santa Catarina, Volume ll Tomo Iil. Rio de Janeiro, 1983

IEGE. Censo Demografico 1970, Santa Catarina, Volume I, Tomo XX. kio de Janeiro, 1973.

IEGE. Censo Demografico 1980, Santa Catarina, Volume I, Tomo V, ng 21. Rio de Janeiro, 1983.

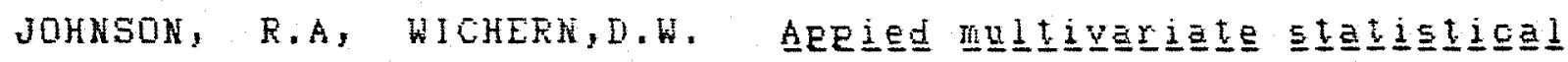
Enalysis. Englewood Clitis, N.J., Frentice Hall. 1962 


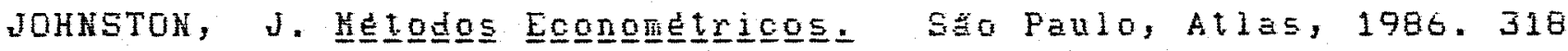
P. ilustrad.

KAGEYAMA, A. A. B GRAZIANO IA SILVA, J. Os resultados da modernicaga agricola dos anos 70 . Estudgs Egongmigos Sao Faulo, 13(3):537-59, set.tdez. 1983.

KageYAHA, A.A. Froblemas metodologioos na mensuraga do emprego agricola. Instituto de Economia/UNICAMP (mimeo), 1986.

KIYUNA, Ikuyo. Modernizago da agricultura e distribuiga da renda no Estado de Sao Paulo, 1980. Firacicaba, 1989. 91P. ilus. Mestrado = Escola Superior de Agricultura "Luiz de Gueiroz"/USP).

KUZNETZ, S. Economic growth and income inequality. Amengigan Egononilic Review2 Nashivilie, Tenn., 45(1): 1-28, mar. 1955.

LAGO, P.F. Gente da Ierra Catarinenge. Florianopolis:Ed. da UFSC/ FCC Edicoes/ Ed Lunardelli/ ULESC, 1988. $352 \mathrm{P}$.

HATTOS, F.M. Santa Catarinal temegs de angtet

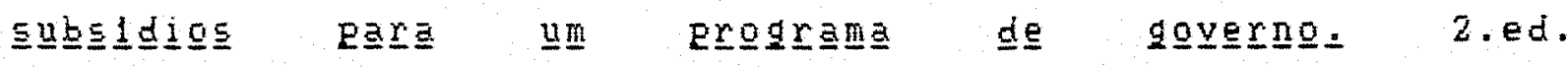
Floriandpolis, Lunardel1i, 1986. 200F.

MESGUITA,O.; GUSMAO, R.; SILVA, S. Modernizacto da agricultura brasileira. Reyista Erasileira de Geggrafia, Rio de Janeiro, 39(4): 3-65, out./ dez. 1977 .

MULLER, G. Estrutura e dinamica do complexo agroindustrial brasileino. Sa Paulo, 1980. Routorado - Universidade de Sa 
Falo).

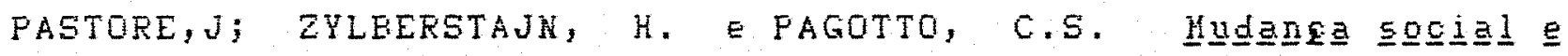

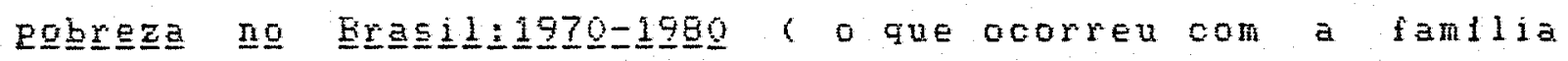
brasileira?). Sao Faulo, Fioneira/FlFE, 1983.

FIAZZA, H. F. Introducao a historia da propriedade rural em Santa Catarina. In: SIMPOSIO NACIONAL IE PROFESSORES UNIVERSITARIOS DE HISTORIA, B., Aracajo, 1975.

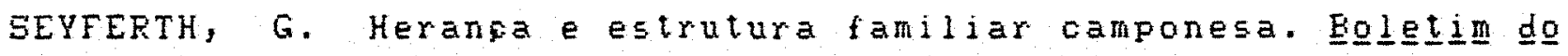

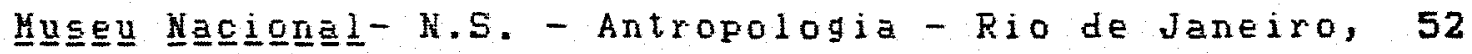
(5): $1-27$, maio. $1985^{3}$

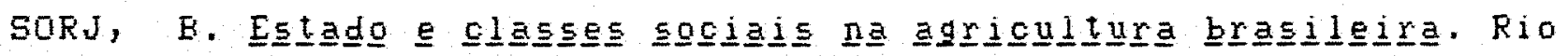
de Janeiro, Zahar Editora, 1980. $152 \mathrm{p}$.

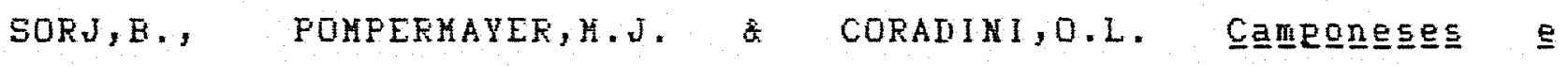

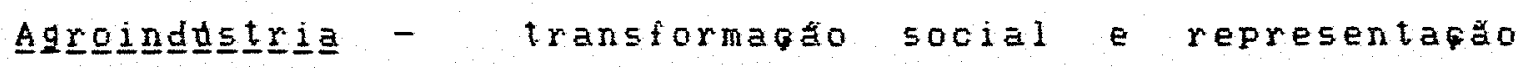
polltica na avicultura brasileira. Rio de Janeiro, Zahar Editora, $1982.119 \mathrm{p}$.

TRONCOSO LEONE, E. Modernizacao e distribuiga de renda na agricultura no Estado da Eahia em 1980. Piracicaba, 1988. CNestrado - Escola Superior de Agrioultura "Luiz de Queiroz", USP). 
APEXDICE 1

CONSTRUCAO DOS INDICADORES DE MODERNIZAGAO 


\section{CONSTRUGAO DOS INDICADORES DE HODERNIZAGAO}

Ko quarto cepitulo, o conceito de nodernizagáfol operacionalizado atraves de irdicadores. Alguns destes indicadores sto informages coletadas diretamente do censo Agropecuario. Outros, entretanto, resultam de combinases ou transformages dos dados censitarios, de modo que e oportuno esclarecer como foram obtidos. As tabelas que estao entreparenteses corresfonden ds tabelas do censo Asropecudrio de 1980 , para o Estado de Santa Catarina.

\section{INDICADORES ASSOCIADOS COH USO DE TECNOLOGIA}

- Iespesas com insumos modernos: soma dos itens adubos $e$ corretivos, sementes e mudas, defensivos agrlcolas. (tabela 85 )

- Despesas com rapoles e medicamentos: soma dos itens medicamentos para animais, sal, racoes industriais e outras raföes. (tabela 85$)$

- Capacidade de armazenage capacidadedos depositos para grăos e outros, em 33 . (tabela 75 )

- Pastagens plantadas: abrange as areas destinadas ao pastoreio e formadas mediante plantio de forragens, do item utizaguo das terras; considera-se a proporga de pasto formado em relacto a area total com pastagem. (tabela 70 )

- Fotencia de trator: fara construga deste indicador, multiflicou-se o ntmero de tratores pela potenoia media dos tratores disponiveis no meroado. Un procedimento alternativo poderia ser adotado, multiplicando o nomero de tratores pela 
potencia media do estreto. Existe uma diferenga de ate $5 \%$ entre es duas maneiras de obter este indicador. (tabela 76 )

- Valor dos Eens: da tabela Bo obteve-sedois indioadores, construldos com o item "instalages E benfeitorias", do Valor dos Eens Indveis, e com o item "maquinas e instrumentos agrarios", de Outros Eens.

\title{
INDICADORES ASSOCIADOS A IYTEYSIFICAGHO DA AGROPECUARIA
}

- Valor da producáo agropecuaria: valor total da producao animal e vegetal. (tabela 83 )

- Litros de leite por vaca ordenhada: quantidade o en 1000 litros) de leite produzido, dividido felo numero de vacas ardenhadas, da Produgäo de Origem Animal . (tabela 94)

\section{INDICADORES ASSOCIADOS AO USO DE CAPITAL FINANCEIRO}

- Financiamentos obtidos: valor total, segundo a origem. (tabela 82,1 tem A)

- Investimentos en compra de animais valor dos investimentos en compra de animais de reproducäo, criafäo outros fins, do ltem Outros Eens. (tabela gi)

\section{INDICADORES ASSOCIADOS A RELACOES SOCIAIS DE PRODUGAO}

\author{
De indicadores de relasos sociais de producto \\ foram construidos de forma a representar as froporobes das \\ categorias trabalho familiar etrabalho assalariado, en relaca
}


ao total de equivalentes-homem. Estas duas oategorias sao estabelecidas como segue:

- trabalho familiar: corresponde ao ntmero de EH da categoria Fesponstvel e membros nắ remunerados da fanilia:

- trabalho assalariado: representa o numero de EH das denais categorias, excluindo despesas com servigos de empreitada quardo a andise incluir confaragăo com os censos anteriores a 1980.

A referenoia de uso de trabalho familiar e trabalho assalariado como indicador de mudanca tecnologica tambem foi eroontrada em HERDT( 1987 ).

\section{OUTROS INDICADORES}

- Area explorada: representa a soma dos itens area de lavouras (fermanentes e temporarias), drea de pastagens (naturais e plantadas) e area de matas nativas e florestas plantadas. (tabela 70$)$

- Area trabalhada: E definida como a soma das areas com Iavouras (permanentes e temporarias), pastagens flantadas e matas Plantadas.

- Area exploravel: area explorada, excluindo-se matas nativas.

\section{OBTEKGAO DE UNIDADE ANIMAL}

De acordo com HOFFMAN et alii (i978, pp.120), o numero total de unidades-animal (uA) pode ser obtido determinando-se a equivalencia da quantidade de alimentagao requerida entre os diferentes animais, admitindo-se que uma unidade-animal seja uma (1) vaca. Seguindo-se este oriterio, 
foram transformados, en valores equivalentes, os efetivos dos rebanhos bovino, sulno e de aves, conforme especificaga abaixo:

\section{Espeoificato}

- bovinos menores de 1 ano

- bovinos de 1 a menos de 2 anos

- bovinos com mais de 2 enos

- suinos de 3 a 6 meses

- suinos com mais de 6 meses

- frangos e galinhas

- gansos e perus
Unidade animal

0,50

0,70

1,00

0,20

0,30

0,01

0,03

\section{OBTENGAO DE EQUIVALENTES-HOMEM}

A pesquisa do Cerso Agropecuario referente a pessoal ocupado abrange todas as fessoas, com ou sen remuneraca, que na data do Censo encontravam-se executando servicos ligados as atividades do estabelecimento. 0 pessoal ocupado ests distribuido for sexo e classe de idade cde 14 anos e mais, e menos de 14 anos), nas seguintes categorias:

- Resfonsavel e membros náo remunerados da familia;

- Enpregados permanentes;

- Empregados temporarios;

- Farceiros:

- outra condiga.

Estas oategorias de pessoal oonpado, somadas a 1tem "servigos de empreitada" das despesas realizadas nos estabelecimentos (tabela 85), forrecem uma aproximasgo do emprego 
agricola. Estas informatges, entretantos devem ser homogeneizadas de tal forma a se ter o ntmero de pessoas ocupadas en unidades de forpa de trabalho. Neste sentido, recorremos ao conceito de equivalente-homem, que corresponde a forga de trabalho de um assalariado homem, adulto, conorome metodologia sugerida for HOFFUANN, coord.(1985, FP.650-655). Una abordagendidatioa sobre o assunto, alem de outros problemas metodoldgicos de mensurafäo de emprego na agricultura, pode ser encontrada em KAGEYAlA $(1986)$.

A transformago dos dados em equivalentes-homem (EH) foi obtida com os seguintes criterios ou fatores de conversä:

- Homens maiores de 14 anos $=1,0$ EH

- Hulheres maiores de 14 anos:

- familiares $=0,6 \mathrm{EH}$

- empregados $=1,0 \mathrm{EH}$

- parceiros e outra condiga $=0,66 \mathrm{EH}$

- Crianfas (menores de 14 años:

- familiares $=0,4$ EH

- empregados e Parceiros $=0,5 \mathrm{EH}$

O servifo de empreitada foi obtido dividindo-se o valor das empreitadas fela diaria media do trabalhador volante e, posteriormente, dividido por Joo. o valor dadiaria fornecido Fela Retrospectiva da Agropecuaria, Fundaga Getulio Vargas, $1980 / 81$.

0. Emprego temporariog de uma rorma geral, e 
sazonal: afresenta periodos de maior intensidade cdurante a safra, nas efocas de tratos oulturais, de colheita, etc.) e outros de menos intensidade (entre-safra). Assim, o emprego tempordrio nádo e calculado da mesma forma que o permanente, nas envolve as informages das tabelas 71 e 73 conso Agropecuario de 1980). Obtem-se uma estimativa do ntmeromedio de trabalhadores temporarios, somando o ntmero de empregados temporarios de janeiro a dezembro e dividindo for 12 (informages obtidas da tabela 73). Este nunero medio anual e multiflicado pela froporga de trabalho tempordrio adulto e proporgáa de trabalho temporario infantil en $31 / 12$, obtido da tabela 71. 


\section{APEXDICE 2}

TABELAS E HISTOGRAMAS 
TABELA 13 - Pessoal ocupado na agropecuária catarinense, em equivalentes-homen-ano, nas microrregiões homogêneas e na unidade da Federação, em 1970.

\begin{tabular}{|c|c|c|c|c|c|c|c|c|}
\hline \multirow{2}{*}{$\begin{array}{c}\text { MICRORREGIAO } \\
\text { HOMOGENEA }\end{array}$} & \multirow{2}{*}{$\begin{array}{l}\text { MAO-DE-OBRA } \\
\text { FAMILIAR }\end{array}$} & \multicolumn{2}{|c|}{ EMPREGADOS } & \multirow{2}{*}{$\begin{array}{l}\text { PARCEIROS } \\
\text { E OUTRA } \\
\text { CONDICAO }\end{array}$} & \multirow{2}{*}{\multicolumn{2}{|c|}{$\begin{array}{c}\text { SERVICO } \\
\text { DE } \\
\text { EMPREITADA }\end{array}$}} & \multirow{2}{*}{$T \circ T A L$} & \\
\hline & & PERMANENTES & TEMPORARIOS & & & & & \\
\hline 292 - Colonial de Joinville & 21148 & 659 & 762 & 120 & & & 22688 & \\
\hline 293 - Litoral de Itajaí & 5.936 & 348 & 471 & 73 & & & 6827 & . \\
\hline 294 - Colonial de Blumenau & 44320 & 1101 & 1344 & 180 & & ; & 46944 & \\
\hline 295 - Colonial Itajai Norte & 11974 & 170 & 281 & 18 & . & & 12443 & \\
\hline 296 - Colonial Alto Itajai & 33772 & 1739 & 2371 & 634 & $\cdot$ & $\cdot$ & 38515 & \\
\hline 297 - Florianópolis & 15.775 & 563 & 869 & 190 & & & 17397 & \\
\hline 298 - Colonial Serrana & 21503 & 594 & 1209 & 160 & & & 23466 & \\
\hline 299 - Litoral de Laguna & 8741 & 166 & 323 & 118 & & & 9348 & \\
\hline 300 - Carbonifera & 36636 & 482 & 1388 & 503 & & & 39009 & \\
\hline 301 - Litoral Sul & 19883 & 251 & 1819 & 375 & & & 22328 & \\
\hline 302 - Colonial Sul & 17067 & 436 & 2106 & 172 & & . & 19781 & \\
\hline 303 - Campos de Lages & 17126 & 2655 & 2115 & 584 & & & 22479 & \\
\hline 304 - Campos de Curitibanos & 28.994 & 2186 & 4647 & 344 & & & $36 \quad 170$ & \\
\hline 305 - Colonial Rio do Peixe & 73263 & 2604 & 2313 & 984 & & & 79168 & \\
\hline 306 - Colonial do Oeste & 131.807 & 1826 & 3530 & 1292 & & & 138454 & \\
\hline 307 - Planalto de Canoinhas & 36710 & 1668 & 4466 & 198 & & & 43041 & \\
\hline Santa Catarina & 524654 & 17444 & 30010 & 5950 & & & 578058 & \\
\hline
\end{tabular}

FONTE: Dados básicos dos Censos Agropecuários de 1970. 
TABELA 14 - Pessoal ocupado na agropecuáría catarinense, en equivalentes-homem-ano, nas microrregiões homogèneas e na unidade da Federação, en 1975.

\begin{tabular}{|c|c|c|c|c|c|c|}
\hline $\begin{array}{l}\text { MICRORREGIAO } \\
\text { HOMOGENEA }\end{array}$ & $\begin{array}{c}\text { MAO-DE-OBRA } \\
\text { FAMILIAR }\end{array}$ & $\begin{array}{c}\text { EMPR } \\
\text { PERMANENTES }\end{array}$ & $\begin{array}{l}\text { GADOS } \\
\text { TEMPORARIOS }\end{array}$ & $\begin{array}{l}\text { PARCEIROS } \\
\text { E OUTRA } \\
\text { CONDICAO }\end{array}$ & $\begin{array}{c}\text { SERVICO } \\
\text { DE } \\
\text { EMPLEITADA }\end{array}$ & TOTA L \\
\hline 292 - Colonial de Joinville & 18909 & 843 & 633 & 123 & 831 & 21338 \\
\hline 293 - Litoral de Itajai & 4557 & 625 & 104 & 19 & 133 & 5437 \\
\hline 294 - Colonial de Blumenau & 46360 & 1030 & 770 & 118 & 338 & 48615 \\
\hline 295 - Colonial Itajai Norte & 14624 & 166 & 262 & 10 & 112 & $15 \quad 174$ \\
\hline 296 - Colonial Alto Itajai & 41509 & 587 & - $\quad 694$ & 140 & 505 & 43434 \\
\hline 297 - Florianópolis & 14705 & 592. & 244 & 52 & 372 & 15964 \\
\hline 298 - Colonial Serrana & 23919 & 293 & 491 & 64 & 205 & 24971 \\
\hline 299 - Litoral de Laguna & 12295 & 131 & 432 & 46 & 59 & 12963 \\
\hline 300 - Carbonifera & 40282 & 732 & 871 & 394 & 368 & 42647 \\
\hline 301 - Litoral Sul & 21056 & 412 & 1212 & 230 & 390 & 23299 \\
\hline $302-$ Colonial Sul & 19565 & 285 & 947 & 463 & 454 & 21714 \\
\hline 303 - Campos de Lages & 17889 & 2841 & 1040 & 505 & 1543 & 23818 \\
\hline 304 - Campos de Curitibanos & 30159 & 2424 & 2570 & 204 & 1515 & 36871 \\
\hline 305 - Colonial Rio do Peixe & 70779 & 3925 & 1416 & 313 & 1639 & $\begin{array}{lll}78 & 071\end{array}$ \\
\hline 306 - Colonial do Deste & 154740 & 2667 & 3273 & 1308 & 3235 & 165223 \\
\hline 307 - Planalto de Canoinhas & 35389 & 2408 & 3822 & 184 & 1037 & 42840 \\
\hline Santa Catarina & 566737 & 19956 & 18.696 & 4173 & 12733 & $622 \quad 377$ \\
\hline
\end{tabular}

FONTE: Dados básicos dos Censos Agropecuários de 1975. 
TABELA 13 - Pessoal ocupado na agropecuária catarinense, em equivalentes-homem-ano, nas microrregiões homogêneas e na unidade da Federação, em 1980.

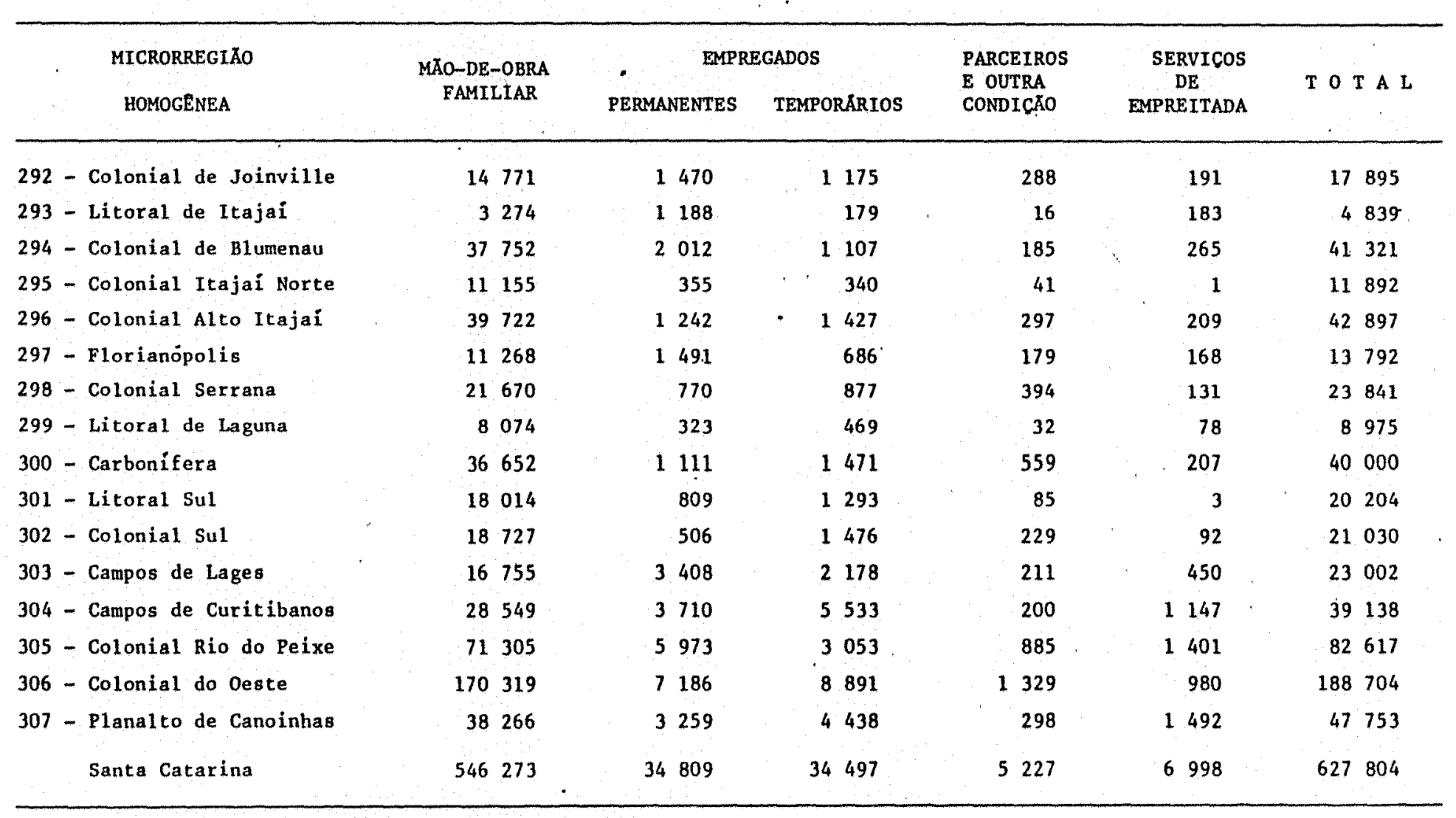

FONTE: Dados básicos dos Censos Agropecuärios de 1980. 
TABELA 16 - Participação relativa dos principais produtos na formação do valor da produção agropecuária nas microrregiōes homogêneas de Santa Catarina, em 1980.

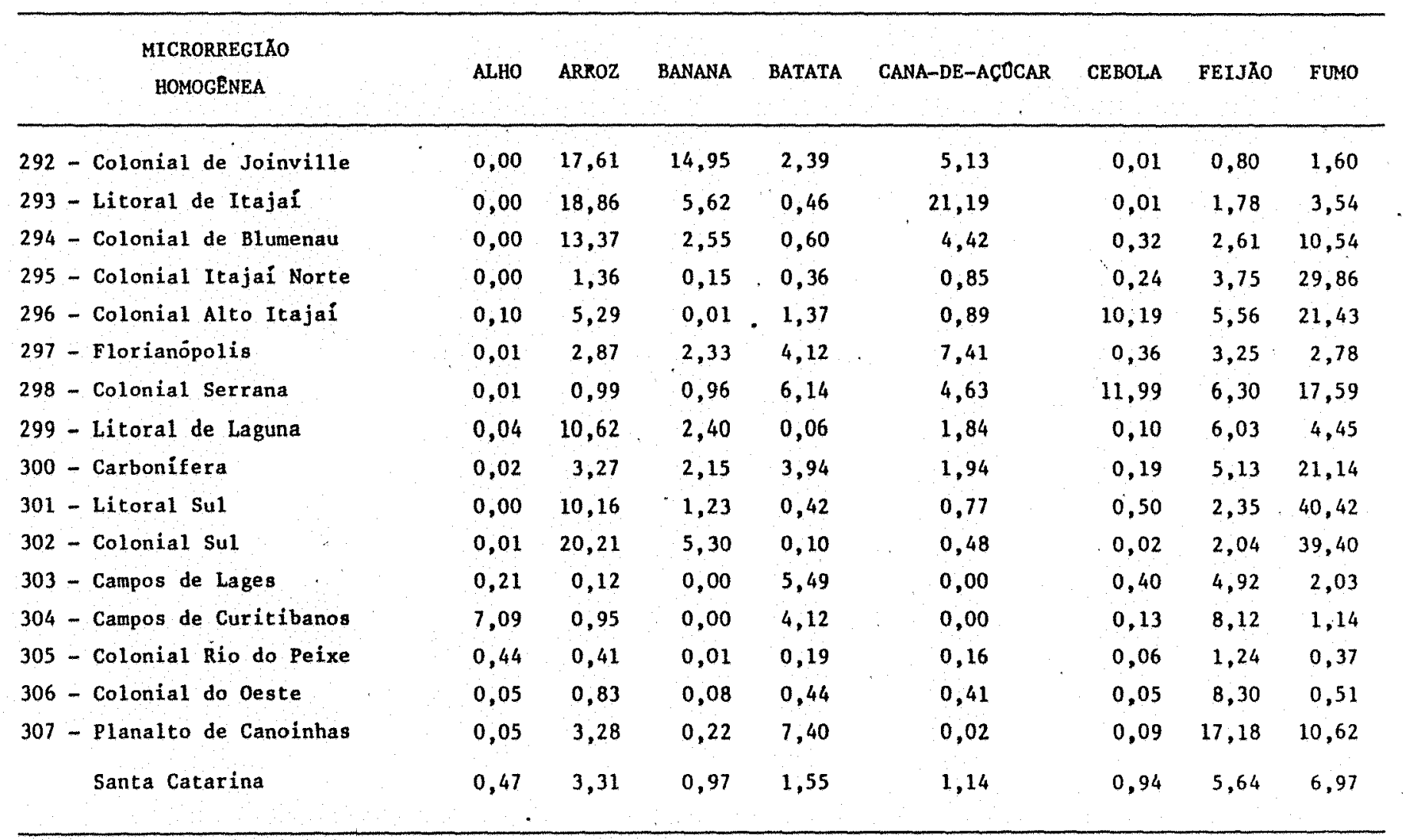

FONTE: Censo Agropecuärio 
TABELA 16- Continuação

\begin{tabular}{|c|c|c|c|c|c|c|c|c|}
\hline $\begin{array}{c}\text { MICRORREGIXO } \\
\text { HOMOGENEA }\end{array}$ & MACA & MANDIOCAR & MILHO & SOJA & AVES & BOVINOS & LEITE & SUINOS \\
\hline 292 - Colonial de Joinville & 0,01 & 7,07 & 4,44 & 0,00 & 18,34 & 5,74 & 15,61 & 6,32 \\
\hline 293 - Litoral de Itajai & 0,00 & 8,22 & 1,88 & 0,00 & 15,50 & 10,85 & 8,60 & 3,50 \\
\hline 294 - Colonial de Blumenau & 0,00 & 11,10 & 6,79 & 0,09 & 14,73 & 6,44 & 18,78 & 7,66 \\
\hline 295 - Colonial Itajaí Norte & 0,01 & 11,01 & 11,85 & 0,25 & 5,72 & 7,45 & 20,32 & 6,81 \\
\hline 296 - Colonial Alto Itajai & 0,04 & 15,32 & 10,42 & $.0,24$ & 4,68 & 4,55 & 13,53 & 6,37 \\
\hline 297 - Florianópolis & 0,00 & 8,69 & 2,36 & 0,00 & 45,04 & 9,14 & 10,00 & 1,63 \\
\hline 298 - Colonial Serrana & 0,03 & 9,98 & 10,47 & 0,04 & 4,38 & 9,20 & 10,96 & 6,34 \\
\hline 299 - Litoral de Laguna & 0,01 & 28,87 & 1,30 & 0,00 & 10,70 & 25,86 & 5,31 & 2,43 \\
\hline 300 - Carbonifera & 0,00 & 10,11 & 7,77 & 0,02 & 8,00 & 9,34 & 9,73 & 17,25 \\
\hline 301 - Litoral Su1 & 0,00 & 18,08 & 2,79 & 0,36 & 8,22 & 8,07 & 4,97 & 1,67 \\
\hline 302 - Colonial Sul & 0,00 & 2,76 & 10,96 & 0,01 & 2,23 & 4,24 & 5,53 & 6,72 \\
\hline 303 - Campos de Lages & 5,15 & 0,07 & 10,95 & 2,53 & 1,94 & 50,70 & 11,84 & 3,67 \\
\hline 304 - Campos de Curitibanos & 0,68 & 0,14 & 19,09 & 16,73 & 4,54 & 24,64 & 6,17 & 6,45 \\
\hline 305 - Colonial Rio do Peixe & 3,90 & 0,77 & 21,56 & 3,51 & 28,09 & 3,81 & 5,18 & 30,29 \\
\hline 306 - Colonial do Oeste & 0,01 & 3,59 & 27,74 & $12 ; 26$ & 10,81 & 3,01 & 5,20 & 26,72 \\
\hline 307 - Planalto de Canoinhas & 0,35 & 2,63 & 17,49 & 13,62 & 3,98 & 5,49 & 7,77 & 9,80 \\
\hline Santa Catarina & 1,10 & 5,04 & 18,58 & 6,50 & 13,79 & 7,31 & 7,64 & 19,05 \\
\hline
\end{tabular}

FONTE: Censo Agropecuário 
TABELA 17 - Participação relativa das microrregióes homogêneas de Santa catarina na formação do valor da produção agropecuária, por produto, em 1980.

\begin{tabular}{|c|c|c|c|c|c|c|c|c|}
\hline $\begin{array}{l}\text { MICRORREGIXO } \\
\text { HOMOGENEA }\end{array}$ & ALHO & ARROZZ & BANANA & BATATA & CANA-DE-ACOCAR & CEBOLA & FEIJAO & FUMO \\
\hline 292 - Colonial de Joinville & 0,01 & 13,62 & 39,33 & 3,95 & 11,48 & 0,02 & 0,36 & 0,59 \\
\hline 293 - Litoral de Itajai & 0,00 & 4,74 & 4,80 & 0,25 & 15,41 & 0,01 & 0,26 & 0,42 \\
\hline 294 - Colonial de Blumenau & 0,01 & 18,18 & 11,82 & 1,73 & 17,39 & 1,55 & 2,09 & 6,81 \\
\hline 295 - Colonial Itajai Norte & 0,00 & 0,52 & 0,20 & $.0,29$ & 0,95 & 0,32 & 0,85 & 5,46 \\
\hline 296 - Colonial Alto Itajaí & 1,23 & 9,15 & 0,09 & $.5,06$ & 4,44 & 62,05 & 5,65 & 17,64 \\
\hline 297 - Florianopolis & 0,04 & 1,70 & 4,70 & 5,21 & 12,70 & 0,75 & 1,13 & 0,78 \\
\hline 298 - Colonial Serrana & 0,04 & 0,63 & 2,07 & 8,34 & 8,52 & 26,80 & 2,35 & 5,32 \\
\hline 299 - Litoral de Laguna & 0.06 & 2,28 & 1,75 & 0,03 & 1,14 & 0,07 & 0,76 & 0,45 \\
\hline 300 - Carbonifera & 0,22 & 5,49 & 12,29 & 14,15 & 9,44 & 1,10 & 5,06 & 16,89 \\
\hline 301 - Litoral Sul & 0,02 & 8,86 & 3,66 & 0,78 & 1,94 & 1,53 & 1,20 & 16,77 \\
\hline 302 - Colonial Sul & 0,03 & 17,22 & 15,35 & 0,18 & 1,19 & 0,07 & 1,02 & 15,97 \\
\hline 303 - Campos de Lages & 1,48 & 0,13 & 0,00 & 11,88 & 0,00 & 1,43 & 2,93 & 0,98 \\
\hline 304 - Campos de Curitibanos & 71,50 & 1,36 & 0,00 & 12,55 & 0,02 & 0,64 & 6,81 & 0,78 \\
\hline 305 - Colonial Rio de Peixe & 21,14 & 2,79 & 0,21 & 2,68 & 3,20 & 1,50 & 4,91 & 1,18 \\
\hline 306 - Colonial do Oeste & 3,66 & 8,47 & 2,63 & 9,51 & 12,11 & 1,67 & 49,65 & 2,48 \\
\hline 307 - Planalto de Canoinhas & 0,55 & 4,86 & 1,12 & 23,41 & 0,09 & 0.49 & 14,96 & 7,48 \\
\hline
\end{tabular}

FONTE: Censo Agropecuärio 
TABELA 17 - Continuação

\begin{tabular}{|c|c|c|c|c|c|c|c|c|}
\hline $\begin{array}{l}\text { MICRORREGIAO } \\
\text { HOMOGENEA }\end{array}$ & MACA & MAND IOC'A & MILHO & SOJA & AVES & BOVINOS & LEITE & sutnos \\
\hline 292 - Colonial de Joinville & 0,02 & 3,59 & 0,61 & 0,00 & 3,41 & 2,01 & 5,24 & 0,85 \\
\hline 293 - Litoral de Itajai & 0,00 & 1,36 & 0,08 & 0,00 & 0,94 & 1,24 & 0,94 & 0,15 \\
\hline 294 - Colonial de Blumenau & 0,01 & 9,92 & 1,65 & 0,06 & 4,81 & 3,97 & 11,07 & 1,81 \\
\hline 295 - Colonial Itajai Norte & 0,01 & 2,78 & 0,81 & 0,05 & 0,53 & 1,30 & 3,39 & 0,45 \\
\hline 296 - Colonial Alto Itajai & 0,19 & 17,43 & 3,22 & 0,22 & 1,95 & 3,57 & 10,16 & 1,92 \\
\hline 297 - Florianōpolis & 0,00 & 3,38 & 0,25 & 0,00 & 6,41 & 2,45 & 2,57 & 0,17 \\
\hline 298 - Colonial Serrana & 0,07 & 4,17 & 1,19 & 0,01 & 0,67 & 2,65 & 3,02 & 0,70 \\
\hline 299 - Litoral de Laguna & 0,01 & 4,07 & 0,05 & 0,00 & 0,55 & 2,51 & 0,49 & 0,09 \\
\hline 300 - Carbonifera & 0,00 & 11,16 & 2,33 & 0,02 & 3,23 & 7,41 & 7,09 & 5,04 \\
\hline 301 - Litoral Sul & 0,00 & 10,37 & 0,43 & 0,16 & 1,72 & 3,19 & 1,88 & 0,25 \\
\hline 302 - Colonial Sul & 0,00 & 1,55 & 1,66 & 0,00 & 0,46 & 1,64 & 2,04 & 1,00 \\
\hline 303 - Campos de Lages & 15,74 & 0,04 & 1,98 & 1,31 & 0,47 & 23,29 & 5,21 & 0,65 \\
\hline 304 - Campos de Curitibanos & 2,92 & 0,14 & 4,86 & 12,16 & 1,56 & 15,92 & 3,82 & 1,60 \\
\hline 305 - Colonial Rio do Peixe & 79,27 & 3,41 & 25,87 & 12,04 & 45,41 & 11,60 & 15,12 & 35,45 \\
\hline 306 - Colonial do Oeste & 0,20 & 24,07 & 50,39 & 63,69 & 26,47 & 13,87 & 22,97 & 47,34 \\
\hline 307 - Planalto de Canoinhas & 1,57 & 2,56 & 4,62 & 10,28 & 1,42 & 3,68 & 4,99 & 2,52 \\
\hline
\end{tabular}

FONTE: Censo Agropecuärio 
d. f.r.

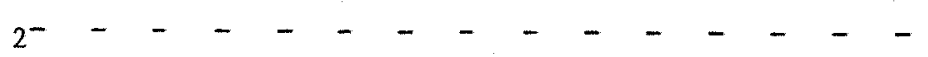

MRH 292-Colonial de Joinville
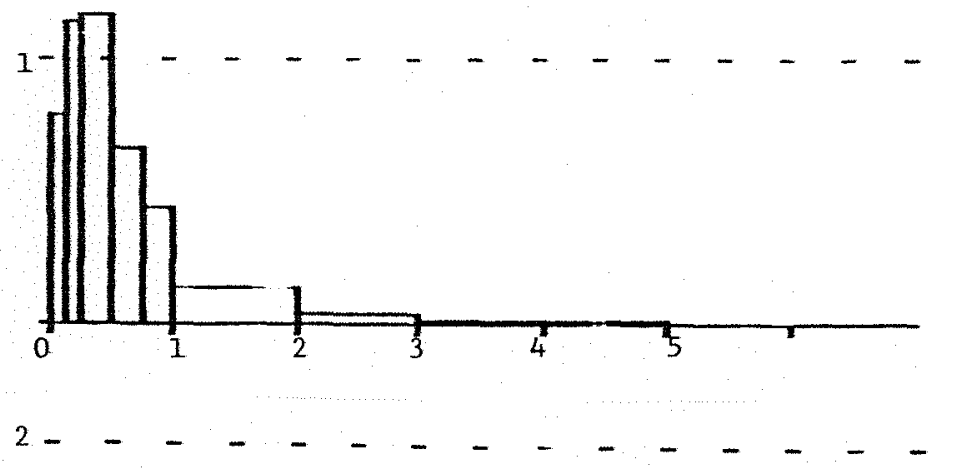

MRH 293-Litoral de Itajaí
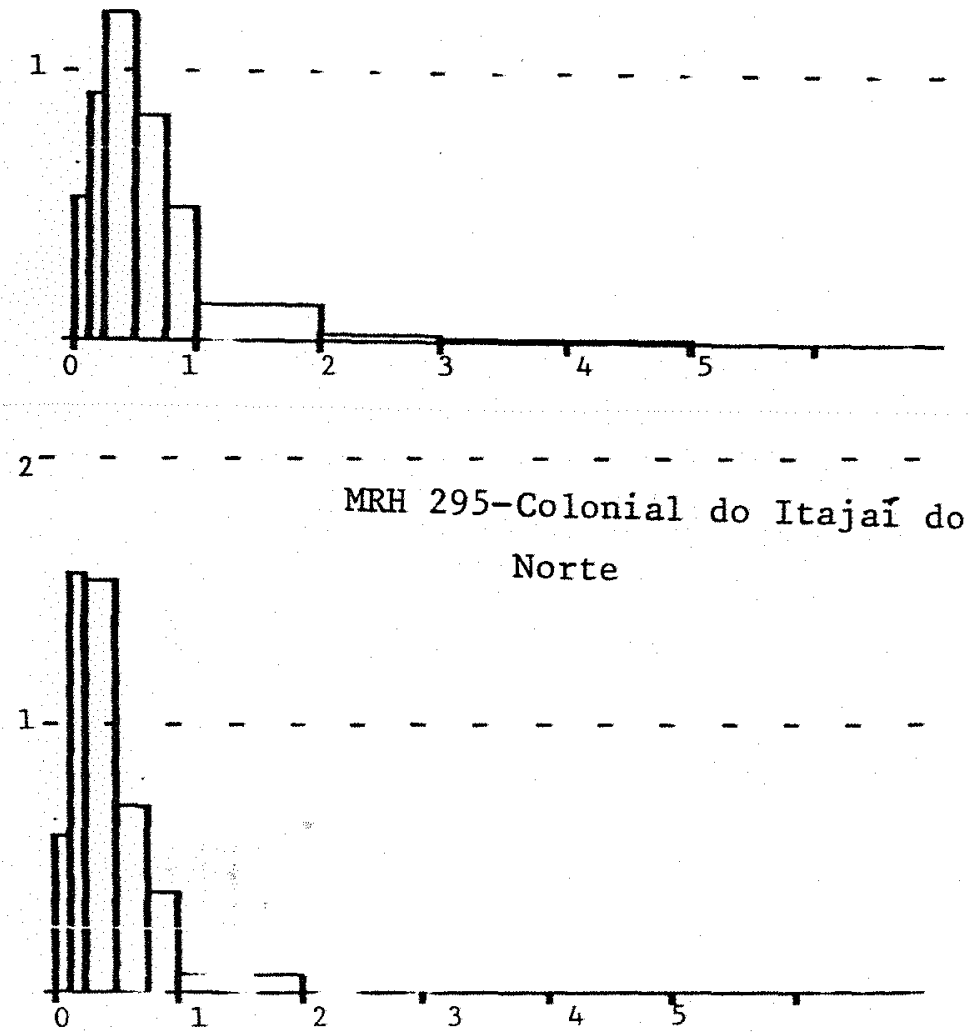

Figura b. Histogramas da distribuiga da renda na agropecudria, segundo as microrregiöes homogeneas $292-c o l o n i a l$ de joinuille, 293-Litoral de Itajal e 295-Colonial do Itajal do Norte, en 1980. (d.f.r. = densidade de frequencia relativa) 

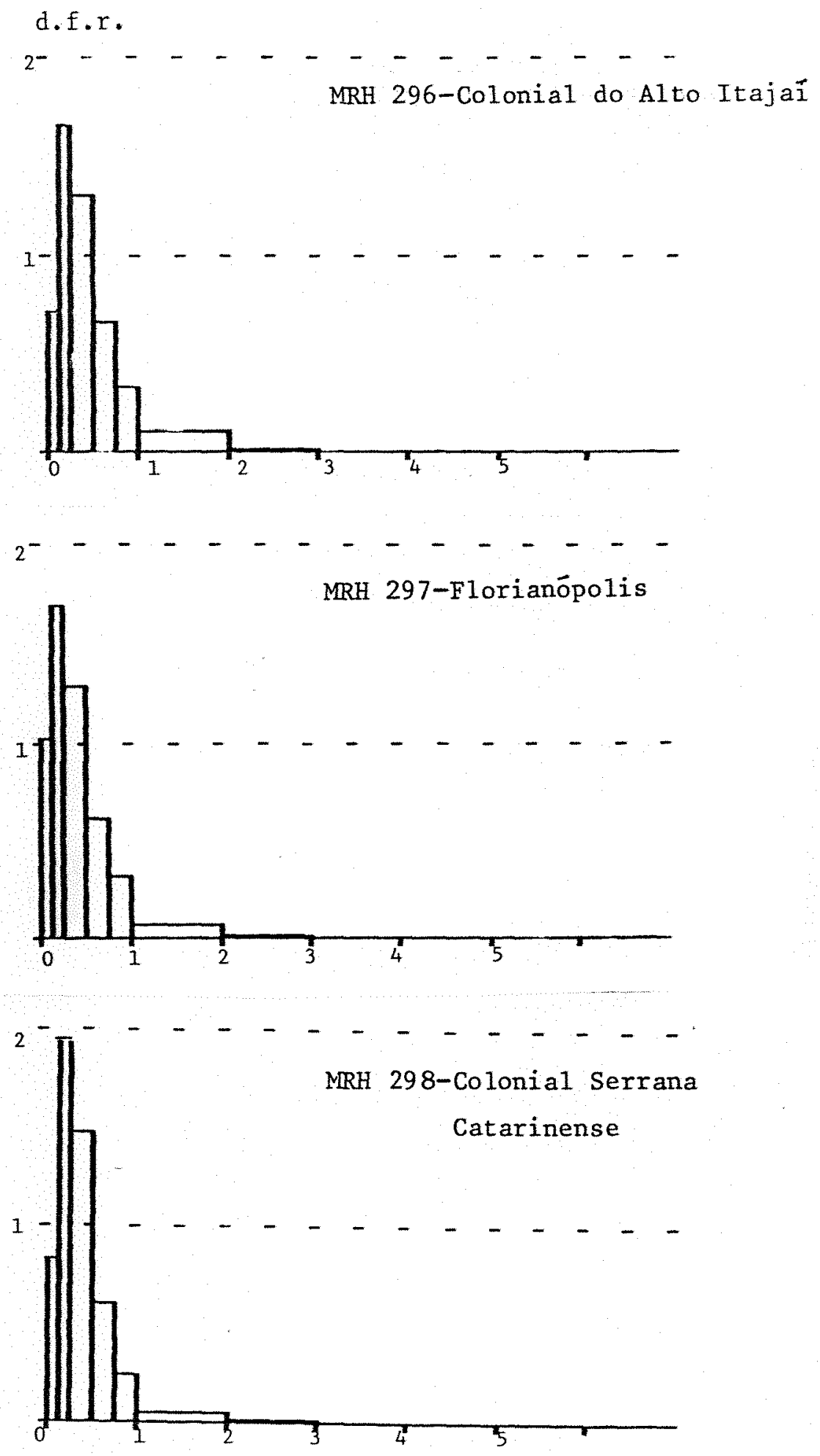

Figura 7. Histograma da distribuifuo da renda na agropecuaria, segundo as microrregibes homogeneas $296-$ colonial do Alto Itajal, 297-Florianbpolis e 298-Colonial Serrana Catarinense.

(d.f.r. = densidade de frequencia relativa). 


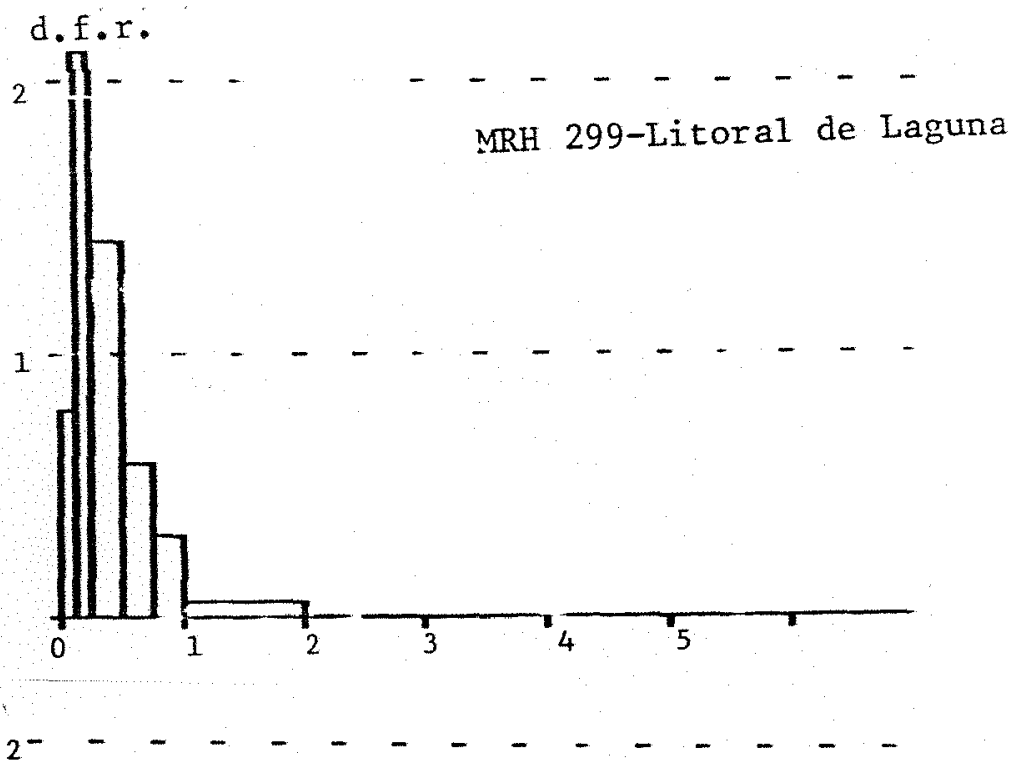

MRH 300-Carbonífera

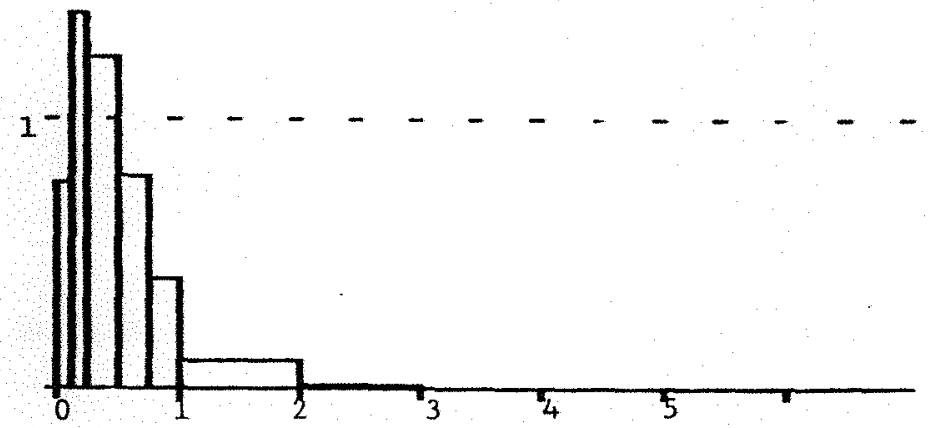

2

MRH 301-Litoral Su1

Catarinense

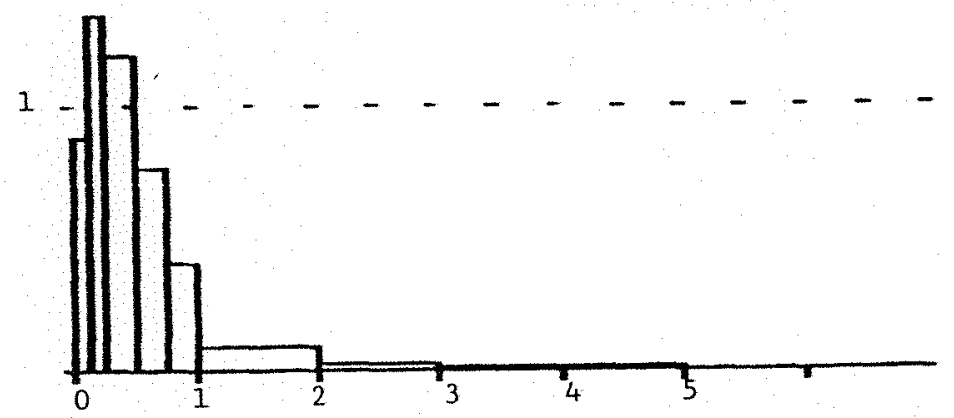

Figura 8. Histogranas da distribuiodo da renda na agropecudria, segundo as microrregiobs homogereas 299-Litoral de Laguna, 300Carbonlfera e 301-Litoral sul Catarinenee, en 1980.

(d. $f . r_{*}=$ deneidade de frequencia relativa). 
d.f.r.

$2----$

MRH 302-Colonial Sul

Catarinense

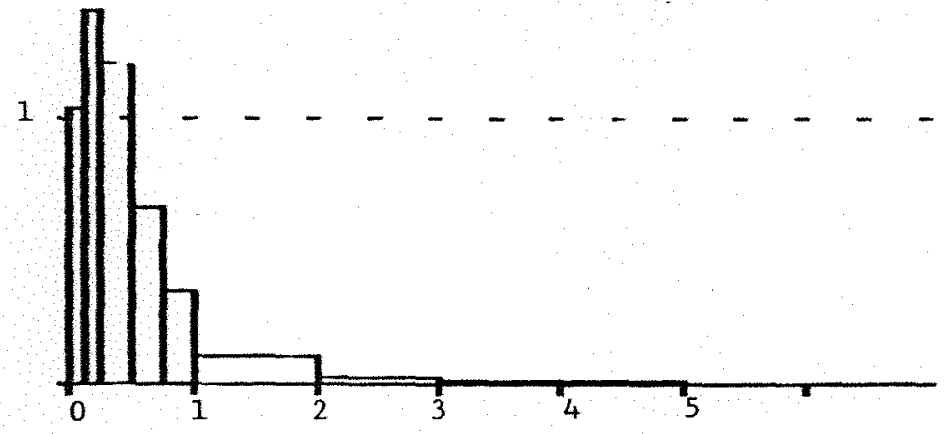

$2--$

MRH 303-Campos de Lages
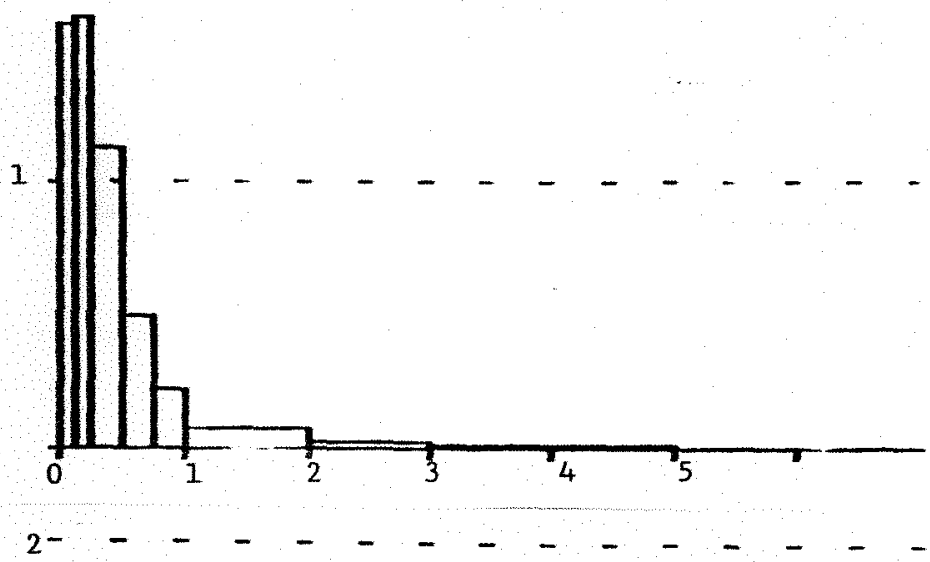

MRH 305-Colonial do Rio

do Peixe

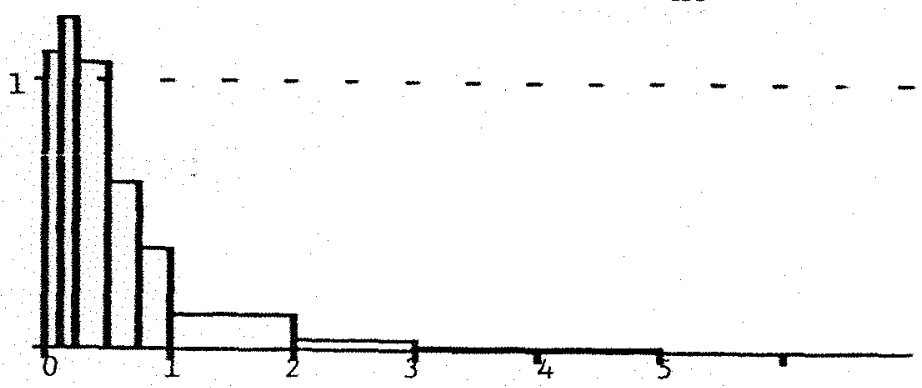

Figura 9. Histogramas da distribuigäo da renda na agrofecuaria, segundo as microrregioes homogeneas 302-colonial Sul Catarinense, 303-Campos de Lages e 305-Colonial do kio do Feixe, em 1980.

(d.f.r. = densidade de frequenoia relativa). 

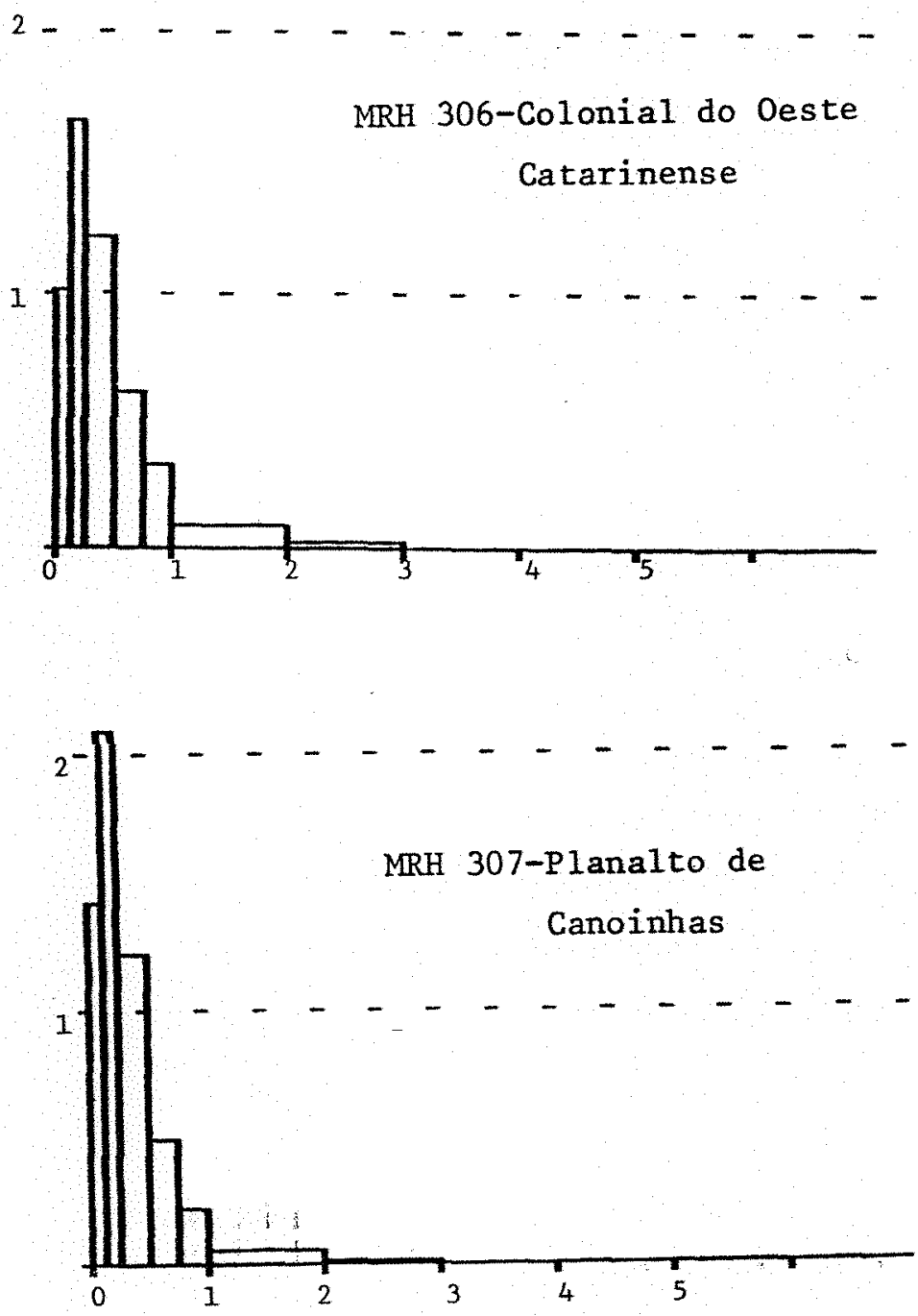

Figura 10. Histogramas da distribuiga renda ra agropecuaria, segundo as microrregiós homogeneas 306-colonial do oeste

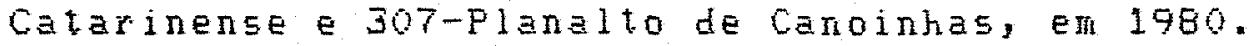
(d.f.r. = densidade de frequencia relativa 